UNIVERSIDADE DE SÃO PAULO

Instituto de Física

Instituto de Química

Instituto de Biociências

Faculdade de Educação

MARCELO KEI SATO

Participação infantil, imaginação e Infância: contribuições para a Divulgação Científica

São Paulo

2019 

Marcelo Kei Sato

Participação infantil, imaginação e Infância: contribuições para a Divulgação Científica

Dissertação Apresentada ao Programa De Pósgraduação Interunidades Em Ensino De Ciências da Universidade de São Paulo para obtenção do título de Mestre em Ensino de Ciências

Área De Concentração: Ensino De Biologia

Orientadora: Prof ${ }^{a} \mathrm{Dr}^{\mathrm{a}}$ Alessandra Fernandes Bizerra

Versão corrigida

São Paulo

2019 
Autorizo a reprodução e divulgação total ou parcial deste trabalho, por qualquer meio convencional ou eletrônico, para fins de estudo e pesquisa, desde que citada a fonte.

\section{FICHA CATALOGRÁFICA \\ Preparada pelo Serviço de Biblioteca e Informação do Instituto de Física da Universidade de São Paulo}

Sato, Marcelo Kei

Participação infantil, imaginação e infância: contribuições para a Divulgação Científica. São Paulo, 2019.

Dissertação (Mestrado) - Universidade de São Paulo. Faculdade de Educação, Instituto de Física, Instituto de Química e Instituto de Biociências

Orientador: Profa. Dra. Alessandra Fernandes Bizerra

Área de Concentração: Ensino de Biologia

Unitermos: 1. Biologia - Estudo e ensino; 2. Divulgação científica; 3. Infância; 4. Imaginação infantil; 5. Participação; 6. Produção de rádio. 
SATO, Marcelo Kei. Participação infantil, imaginação e Infância: contribuições para a Divulgação Científica. Dissertação apresentada ao Programa De Pós-graduação Interunidades Em Ensino De Ciências da Universidade de São Paulo para obtenção do título de Mestre em Ensino de Ciências.

Aprovado em:

Banca Examinadora

Prof. Dr.

Instituição:

Julgamento:

Assinatura:

Prof. Dr.

Instituição:

Julgamento:

Assinatura:

Prof. Dr.

Instituição:

Julgamento:

Assinatura: 

Às crianças de Passos Maia (SC) e Ponte Serrada (SC), as verdadeiras professoras e mestras dessa estória... 



\section{AGRADECIMENTOS}

Em primeiro lugar agradeço a minha mãe, Sueli, meu pai, Celso, e a meu irmão, Thiago, por todo apoio e pelo cenário favorável durante todas as etapas de minha formação profissional e humana. Obrigado pelas inúmeras caronas em horários horrorosos que me permitiram dormir um pouco mais no carro entre a Penha e o Butantã.

Agradeço também a minha querida orientadora, Prof ${ }^{a}$ Alessandra Bizerra, por toda a força ao longo desses muitos anos de parceria. Como minha principal mentora, a Alê me guiou desde as dúvidas de um graduando em seu segundo ano de faculdade até o presente momento, abraçando todas as minhas ideias, por mais malucas que fossem, e, claro, me convidando a participar de diversos de seus próprios projetos malucos.

Fica meu agradecimento também ao CHOICES, grupo de pesquisa em que cresci e me construí enquanto pesquisador ao lado de amigos brilhantes, e ao GEPSI, em especial à Prof ${ }^{\mathrm{a}}$ Maria Letícia Nascimento, por me acolher durante o curto período em que consegui frequentar as discussões e aprender um pouco mais sobre as crianças e suas culturas.

Ao pessoal do Instituto Espaço Silvestre, em especial a minhas amigas Vanessa Kanaan e Ligia Jahn, obrigado pelas diversas aventuras envolvendo os roxinhos e o Parque Nacional das Araucárias. Sem uma forte parceria, essa pesquisa não seria possível.

Aproveito para agradecer também à CAPES, ao Programa de Pós-Graduação Interunidades em Ensino de Ciências e à Universidade de São Paulo pela bolsa de estudos e pela estrutura em que ocorreu essa pesquisa.

Às crianças de Ponte Serrada e Passos Maia, muito obrigado por me acolherem como um amigo um pouco grande (mas nem tanto). Carregarei para sempre no coração todas as tardes que passamos brincando e conversando ao longo dos meses que passamos juntos.

A meus alunos, obrigado por me ensinarem tanta coisa e por aguentarem meu mau humor no período em que essa dissertação estava sendo finalizada.

A todos os meus amigos da Bio, em destaque a Ana Sophia, Ursula, Kyoshi, Amanda, Arthur, Gabriela, Lucas, Maria Caroline e todos os demais do grupo da copa, obrigado pelas conversas e pelas noites na Eiras. 
À equipe do “Alô, Ciência?", saibam que estaremos sempre juntos, queridos companheiros e companheiras, na busca de um mundo mais justo e democrático. Para além de um grupo de Divulgação Científica, vocês são meus parceiros de luta e de transformação.

Por fim, mas não menos importante, obrigado Carolina, meu bem, por ser sempre minha parceira de aventuras, diversão máxima e perrengues acadêmicos. Que nossos sonhos conjuntos de construção de um mundo melhor se realizem! 


\section{RESUMO}

SATO, Marcelo Kei. Participação infantil, imaginação e Infância: contribuições para a Divulgação Científica. 2019. 128p. Dissertação (Mestrado em Ensino de Ciências). Instituto de Biociências, Universidade de São Paulo, São Paulo, 2019.

Esse trabalho investiga os modos de participação de crianças em ações educativas e de Divulgação Científica (DC) na coprodução de mídias "rádio" e "audiovisual”, dentro do contexto do projeto "Reintrodução do papagaio-de-peito-roxo no Parque Nacional das Araucárias, SC" realizado em parceria com o Instituto Espaço Silvestre, as Secretarias de Educação dos Municípios de Passos Maia e Ponte Serrada e três escolas municipais da região. Por meio das abordagens teórico-metodológicas da DC enquanto cultura (Estudos Culturais) e com foco em ações participatórias, buscou-se localizar nos dados obtidos os diferentes modos de Participação Infantil nas ações de coprodução de mídias. Foram coletados e analisados os registros audiovisuais das ações, o caderno de campo do pesquisador e as mídias coproduzidas com e pelas crianças participantes (dez episódios de radionovela e dois audiovisuais). Como resultados das análises emergiram quatro modos principais de Participação Infantil nas ações de DC de coprodução de mídias: (1) contextualizada, (2) simbólica, (3) técnica/estética e (4) identitária. Apesar de não ser a intenção dessa pesquisa esgotar todo e qualquer modo de participação das crianças em ações participatórias de DC, considera-se que essa pesquisa constitui um importante passo, ainda que inicial, para a sistematização de um diálogo entre as áreas de pesquisas e práticas de DC participatórias e os estudos da infância.

Palavras chave: Divulgação Científica, Participação Infantil, Infância, Coprodução de mídias, Mídias participatórias. 


\section{ABSTRACT}

\section{SATO, Marcelo Kei. Children participation, imagination and Childhood: contributions to}

the Science Communication. 2019. 128p. Thesis (Teaching of Sciences Master's Degree). Instituto de Biociências, Universidade de São Paulo, São Paulo, 2019.

This research investigates the ways in which children participate in educational and Science Communication actions in the co-production of "radio" and "audiovisual" media, within the context of the project "Reintroduction of vinaceous-breasted amazon in the Araucaria's Nacional Park, SC" in partnership with the Espaço Silvestre Institute, the Education Departments of the Municipalities of Passos Maia and Ponte Serrada and three schools in the region. Through the theoretical and methodological approaches of Science Communication as a culture (Cultural Studies) and focusing on participatory actions, the objective was to locate in the data obtained the different modes of child participation in media co-production actions. The audiovisual records of the actions, the researcher's field notebook and the media co-produced with and by the participating children (ten episodes of radio stories and two audiovisuals) were collected and analyzed. As a result of the analysis, four main modes of child participation emerged in the actions analyzed: (1) contextualized, (2) symbolic, (3) technical/aesthetical and (4) identitary. Although it is not the intention of this research to exhaust any and every mode of participation of children in participatory actions of Science Communication, it is considered that this research constitutes an important, although initial, step in systematizing a dialogue between research and practice in Participatory Science Communication and childhood studies.

Key Words: Science Communication, Children Participation, Childhood, Media co-production, Participatory Media. 


\section{LISTA DE FIGURAS}

Figura 1. Escada de Participação Cidadã (ARNSTEIN, 1969).

Figura 2. Esquema de circuito da cultura (DU GAY et al., 1997).

Figura 3 Exemplo de material do Instituto Espaço Silvestre com chamado para ciência-cidadã.

Figura 4. Arte com o papagaio-de-peito-roxo em vidro traseiro do carro oficial da Secretaria Municipal da Educação (SME) de Passos Maia.

Figura 5. Exemplo de placa colocada nos arredores do Parque Nacional das Araucárias, SC.

Figura 6. Logomarca do Parque Nacional das Araucárias, SC.

Figura 7. Estrutura de um Episódio Simples (STEIN; GLENN, 1975).

Figura 8. Transformações estéticas em "O Papagaio e os amigos dele".

Figura 9. Cenas de "Tobi, Susu e a tempestade". 


\section{LISTA DE TABELAS}

Tabela 1. Transcrição de episódios.

Tabela 2. Resumo dos contextos de produção das estórias.

Tabela 3. Síntese das representações presentes nas estórias. 
3.2 Divulgação Científica enquanto cultura $\quad 35$

3.2.1 Circuito da Cultura na Divulgação Científica 38

3.3 Cultura participatória e alfabetização em novas mídias $\quad \mathbf{4 2}$

3.3.1 Mídias participatórias e a construção de identidades $\quad 45$

4. INFÂNCIA E A DIVULGAÇÃO CIENTÍFICA

4.1 Participação infantil $\quad 51$

4.2 Participação infantil na DC: culturas da infância e imaginação 54

5. ABORDAGEM TEÓRICO-METODOLÓGICA

5.1 Instituições parceiras

$\begin{array}{ll}\text { 5.1.1 Instituto Espaço Silvestre } & 59\end{array}$

5.1.2 Escola de Tempo Integral Tancredo de Almeida Neves $\quad 62$

5.1.3 Escola Municipal Rural Maria Francisca Maciel 63

5.1.4 Escola de Educação Infantil e Ensino Fundamental Nossa Senhora Aparecida 64

$\begin{array}{lr}5.2 \text { Descrição das ações } & 64\end{array}$

$\begin{array}{lr}5.3 \text { Produção dos dados } & 68\end{array}$

$\begin{array}{ll}\text { 5.3.1 Registro audiovisual das ações } & 69\end{array}$ 


\section{REFERÊNCIAS}

\section{APÊNDICES}

A floresta escondida

$\begin{array}{lr}\text { O Papagaio Rico e os seus amigos } & 121\end{array}$

O Papagaio Dedé e o Dragão! 122

Os passarinhos e o Monstro de Ferro! 123

$\begin{array}{ll}\text { A guerra contra os cortadores de árvores } & 124\end{array}$

O papagaio-de-peito-roxo e a Bruxa! 125

$\begin{array}{ll}\text { O Papagaio e os amigos dele } & 126\end{array}$

$\begin{array}{ll}\text { Termo de consentimento livre e esclarecido } & 127\end{array}$ 


\section{Apresentação}

“(...) fräulein... nome esquisito! nunca vi! que bonitas assombrações havia de gerar na imaginação das crianças! era só deixar ele descansar um pouco na ramaria baralhada, mesmo inda com poucas folhas, das associações infantis, que nem semente que dorme os primeiros tempos e espera. então espigaria em brotos fantásticos, floradas maravilhosas como nunca ninguém viu. porém as crianças nada mais enxergariam entre as asas daquela mosca azul... elza lhes fizera repetir muitas vezes, vezes por demais a palavra! metodicamente a dissecara. "fräulein" significava só isto e não outra coisa. e elas perderam todo gosto com a repetição. a mosca sucumbira, rota, nojenta, vil. e baça.."

Mário de Andrade

Nasci em 1993 e cresci num contexto em que estavam em alta o sequenciamento genômico, a clonagem da ovelha Dolly e o Dr. Albieri da novela "O Clone”. Fui também um ávido consumidor de grandes documentários e programas infantis de vida selvagem. Com isso, desde muito cedo comecei a construção de um discurso de "ser biólogo quando crescer". Apesar dessa intenção, o contato que tive com a Biologia na escola acabou não sendo estimulante. Foram minhas visitas a zoológicos, parques e constantes viagens ao interior de São Paulo que concretizavam esse sentimento que havia construído de "ser biólogo". Com essa bagagem, acabei embarcando no curso de Bacharelado e Licenciatura em Ciências Biológicas na Universidade de São Paulo (USP), em 2011. Com o apoio incondicional e suporte estrutural de minha família, esse caminho foi tranquilo e prazeroso.

Apesar das idas e vindas e diversos momentos de conflito interno me formei Biólogo em 2016, me encontrando nas ações educativas dentro e fora das salas de aula. Durante minha vivência universitária fui educador de um espaço de educação não formal, professor de cursinho popular e produtor de mídias de Divulgação Científica. Mais recentemente me tornei professor de Ciências do Ensino Fundamental 2 em uma carreira que espero que ainda dure por muito tempo.

Quebrando a tradição cronológica dos relatos, retornarei rapidamente alguns anos para contar de outro viés, como classificaria Gaston Bachelard (2009), um pouco mais noturno de minha formação. Paralelamente às descobertas acadêmicas, encontrei nas artes os momentos introspectivos de devaneio. Desde cedo me divertia com retalhos de papel, os quais acabaram 
se tornando brinquedos ou presentes, alguns guardados até hoje por minha mãe. Na música me descobri (infelizmente) melhor apreciador do que produtor (apesar de minhas extensas tentativas nos mais diversos instrumentos). Mais tarde, tive oportunidades de passear pelas mídias digitais, produzindo centenas de cartazes de festas do Centro Acadêmico da Biologia USP, algumas dezenas de episódios de podcasts, milhares de fotografias e alguns vídeos. Aprendi a ouvir e contar estórias com duas grandes mestras, Fabiana Rubira nos encontros semanais de Narração de Histórias do Laboratório de Arte Educação da Faculdade de Educação da USP; e Célia Gomes no Curso Básico de Formação para Contadores de Histórias da Secretaria Municipal de Bibliotecas de São Paulo. Elas me ajudaram a montar minha bagagem e uma nova forma de compartilhar um pouquinho de meus conhecimentos.

Em meus momentos de alegria, disfarçados de estágio, frequentei por alguns meses de 2014 a Creche/Pré-Escola Oeste da USP. Das brincadeiras, conversas e aprendizagens com as crianças, me encantei com o universo do brincar, da imaginação e da criação sem os rígidos limites que o real impõe com o passar do tempo. Essa ação rendeu minha iniciação científica, apresentada com o título "Contação de estórias, Ensino de Ciências e Educação Infantil: criação, imaginação e realidade" na disciplina Pesquisa em Biologia para a conclusão do curso de bacharelado em Ciências Biológicas, depois apresentado no VII Congresso Paulista de Educação Infantil e III Simpósio Internacional de Educação Infantil, em São Carlos/SP em 2015 (SATO; PRADO, 2015). Fiz desse contato o primeiro de muitos, realizando alguns estágios e projetos de disciplinas e visitas às crianças, educadoras e funcionárias. Em 2015 fiz um relato de minhas experiências, como convidado de uma mesa redonda, no I Encontro Faculdade de Educação e Creches/Pré-escolas da USP/SP, evento criado em defesa das creches da USP, em resposta ao forte descaso da reitoria da universidade. Apesar da mobilização dos três setores da USP, a Creche Oeste permanece fechada desde o início de 2017, interpretando de maneira não consensual a decisão do Conselho Universitário ${ }^{1}$ (maior órgão deliberativo da USP).

Foi da interseção entre as áreas que tanto participaram de minha formação (DC, Contação de Estórias, produção de mídias e a Participação Infantil) que decidi me aventurar novamente, dessa vez no curso de Mestrado do Programa de Pós-Graduação Interunidades em

\footnotetext{
${ }^{1}$ Foi deliberado no Conselho Universitário de 08 de novembro de 2016 que seriam preenchidas as vagas ociosas nas creches/pré-escolas da USP até sua capacidade total. Pretendia-se assim abrir as mais de 150 vagas ociosas para o atendimento às crianças. Entretanto, a alternativa encontrada pela reitoria da Universidade para o preenchimento das vagas até a totalidade foi o fechamento da Creche/Pré-escola Oeste com realocação de todo o corpo de funcionárias e crianças para a Creche/Pré-Escola Central da USP.
} 
Ensino de Ciências. O trabalho a seguir é o fruto das reflexões de um biólogo contador de estórias que tem os pés na Divulgação Científica e o coração nas culturas da infância. Assim, o foco desta dissertação se dará nas ações de coprodução de mídias de Divulgação Científica $(\mathrm{DC})^{2}$ participativas para e com crianças.

2 Apesar das diferentes denominações (popularização, comunicação, entre outros), optou-se por utilizar Divulgação Científica por ser um dos termos mais utilizados no cenário nacional (MOREIRA; MASSARANI, 2002; CASTELFRANCHI, 2010; FALCÃO, 2009). Na língua inglesa, optou-se pelo uso do termo science communication tanto no corpo do texto quanto no uso em bases de dados pelos mesmo motivos. 


\section{Introdução}

A partir dos dados obtidos na última pesquisa de Percepção Pública de Ciência e Tecnologia (MCTI, 2019), observa-se que 62\% dos brasileiros entrevistados afirmaram estar muito interessados ou interessados em Ciência e Tecnologia, e esse valor sobe quando questionados sobre os tópicos Medicina e Saúde (79\%) e Meio Ambiente (76\%). Esses dados indicam o grande potencial que as ações de educação científica possuem, visto que há um interesse nos temas das ciências por boa parte da população brasileira. Entretanto, o acesso a informações de Ciência e Tecnologia pelos meios de comunicação não é proporcional a esse interesse. Das sete mídias: (1) livros, (2) programas de rádio, (3) jornais impressos, (4) revistas, (5) conversas com amigos, (6) internet e redes sociais e (7) programas de $T V$, apenas o último meio de comunicação foi recordado por mais de $40 \%$ dos entrevistados como veículo de temas científicos.

Tais números expõem uma necessária discussão acerca dos materiais sobre ciência e tecnologia disponibilizados nos demais tipos de mídias. Se a maioria dos brasileiros se interessam por esses temas, quais são as ações necessárias para promover esse contato entre os interessados e a comunidade científica? Há escassez de materiais de Divulgação Científica ou falta de interesse na forma como essa divulgação tem sido feita? Será que a participação de pessoas externas à comunidade acadêmica na produção desses materiais auxilia na promoção dessa relação da ciência na sociedade?

No que diz respeito à pesquisa em Divulgação Científica voltada para crianças, nota-se que ainda é uma área recente e em construção. Quando buscado os termos "Science communication" e "children/childhood/early age/kid" na base de dados Web Of Science, são retornados 45 resultados, variando os anos de publicação de 2006 a 2019. Já no cenário nacional, também é possível encontrar alguns trabalhos com as atividades museais (BIZERRA et al., 2009; ISZLAJI, 2012; LEPORO, 2015) e de outras ações de Divulgação Científica voltadas para as crianças como livros e revistas (SCALFI, 2014; MASSARANI et al., 2005). Em relação às práticas de atividades de DC para as crianças pela internet, existem alguns materiais disponíveis, como os canais da plataforma de vídeos YouTube: Manual do Mundo ${ }^{3}$,

\footnotetext{
${ }^{3}$ Disponível em < https://www.youtube.com/user/iberethenorio>, acesso em 29 dez 2017.
} 
O Incrivel Pontinho Azul ${ }^{4}$, Ponto em Comum ${ }^{5}$ e Ticolicos - Canal Infantil ${ }^{6}$ e sites como da Universidade das Crianças $^{7}$, da Universidade Federal de Minas Gerais (UFMG), e da Revista Ciência Hoje das Crianças ${ }^{8}$. Essas iniciativas possuem os mais diversos objetivos, sendo que muitas vezes o mesmo projeto acaba produzindo materiais de diferentes naturezas. No caso do Ticolicos - Canal Infantil, seu objetivo principal não é o de Divulgação Científica, mas sim de produzir conteúdo educativo de diversas naturezas para crianças como: arte, literatura, matemática, entre outras. Dentro dessa ação, os materiais voltados para divulgação das ciências aparecem principalmente nas entrevistas a profissionais baseadas em dúvidas das crianças, no quadro Qual é a sua dúvida?. Tais conteúdos possuem diferentes níveis de participação das crianças, alguns expositivos (propostas de atividades e experimentos, vídeos explicativos de conceitos, etc.), outros consultivos (materiais baseados em perguntas das crianças). Segundo Sarmento (2003), pode-se caracterizar tais práticas como para das culturas infantis criadas para as crianças. Entretanto, como defende o autor, não podem ser considerados como parte da cultura produzida pelas crianças, conceituado como culturas da infância e definido pelo autor como:

(...) a capacidade das crianças de construírem de forma sistematizada modos de significação do mundo e de ação intencional que são distintos dos modos adultos de significação e ação (SARMENTO, 2003, p. 3).

Dentro da perspectiva da Sociologia da Infância (SI), as crianças são compreendidas enquanto sujeitos de direitos e produtoras de cultura (CORSARO, 2011; SARMENTO, 2003). Com a Convenção sobre os Direitos da Criança (ONU, 1989), foram estabelecidos três tipos de direitos das crianças: (1) de provisão, (2) de proteção e (3) de participação. Com isso, a infância tem sido considerada uma categoria geracional, a criança é tanto um ser biológico (um humano em desenvolvimento que tem direito de provisão e de proteção) quanto um ser social (provido de vontades e direitos, incluindo o direito de participação).

Nesse entendimento, é notável a falta de atividades de Divulgação Científica que valorizem esse conhecimento das crianças enquanto sujeitos com direito de participação e cocriadoras de conhecimentos e produtos. Ainda, as ações que possuem algum nível de

\footnotetext{
${ }^{4}$ Disponível em $<$ https://www.youtube.com/channel/UCOLnE7ioY6Bax 3AiiXDg7g $>$, acesso em 29 dez 2017.

${ }^{5}$ Disponível em $<$ https://www.youtube.com/channel/UCGo3vjM2L13XujL-zYT5SMg>, acesso em 29 dez 2017.

${ }^{6}$ Disponível em $<$ https://www.youtube.com/user/ticolicos $>$, acesso em 29 dez 2017.

${ }^{7}$ Disponível em $<$ http://www.universidadedascriancas.org/>, acesso em 29 dez 2017.

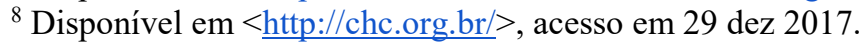


participação dificilmente ultrapassam o limite da consulta, atribuindo aos adultos a palavra final na escolha dos conteúdos e na forma que serão apresentados.

Dessa discussão sobre a escassez de práticas e pesquisas de DC em que o público infantil participa ativamente, algumas questões emergem:

- Quando assegurada a participação ativa das crianças em ações de DC, de que modos essa participação se manifesta?

- Quais os desafios para promoção dessas práticas?

Para tentar responder a essas questões, o texto a seguir foi sistematizado nos seguintes tópicos:

- Em “Objetivos” são apresentados os objetivos gerais e específicos dessa pesquisa.

- Em "Divulgação Científica e participação" é realizado um levantamento teórico da área da DC, em especial das concepções participativas e participatórias $^{9}$. É apresentada também a ferramenta teórico-metodológica do circuito de cultura (DU GAY et al., 1997) e a concepção de DC enquanto fenômeno cultural (DAVIES; HORST, 2016).

- Em "Infância e a Divulgação Científica" são apresentados alguns conceitos e concepções dos estudos da infância, em especial a Participação Infantil e buscou-se realizar uma primeira aproximação com os conceitos de Divulgação Científica enquanto fenômeno cultural.

- $\mathrm{Na}$ "Abordagem teórico-metodológica" são apresentados os pressupostos teórico-metodológicos utilizados na pesquisa, a produção dos dados e o quadro analítico.

- Nos "Resultados e discussão" são apresentados os principais resultados da pesquisa, discutindo a relação entre os dados empíricos da pesquisa e os referenciais teóricos e discorrendo sobre os modos de Participação Infantil em práticas de coprodução de mídias de DC participatória.

\footnotetext{
9 Optou-se pelo uso do termo "participatório" ao longo do texto quando se referir a modos específicos de participação ativa (coprodução, influência nas tomadas de decisão) e do uso "participativo" em uma concepção mais ampla que envolva modos de participação menos ativos (consulta).
} 
- Por fim, nas "Considerações finais" os resultados são sistematizados e acompanhados de novas reflexões acerca dos caminhos e possibilidades para a área de pesquisas e práticas participatórias de DC para e com crianças. 


\section{Objetivos}

\subsection{Objetivo Geral}

Compreender os modos de Participação Infantil na Divulgação Científica, considerando-se as culturas da infância e modelos participatórios de comunicação da ciência. Espera-se, com isso, contribuir para o desenvolvimento de modelos de comunicação da ciência que valorizem a infância e a Participação Infantil na coprodução de mídias.

\subsection{Objetivos específicos}

1. Compreender os modos de participação das crianças no processo de produção de estórias para a conservação do papagaio-de-peito-roxo através das mídias "rádio" e "audiovisual".

2. Ampliar o conhecimento sobre as possíveis contribuições e limitações da Participação Infantil na Divulgação Científica por meio da coprodução de estórias e mídias. 


\section{Divulgação científica e participação}

A Divulgação Científica (DC) enquanto objeto de estudo teórico e empírico é relativamente recente se comparada à prática de comunicar conteúdos científicos para ou com o público não acadêmico (BUCCHI; TRENCH, 2008). Práticas como a publicação de livros científicos em um idioma que não fosse o latim, no século XVII, podem ser consideradas importantes para a origem das concepções de Divulgação Científica. A tentativa de superação da barreira linguística revela uma intencionalidade em comunicar para além dos pares, ainda que existissem barreiras de outras naturezas, como cognitivas, culturais ou simbólicas (TURNEY, 2008; MERIGOUX, 2014). Com o lançamento, no século XVIII, da Encyclopédie, editada por Denis Diderot e Jean le Rond d'Alembert, bem como de outros livros com temas científicos, temos registro de publicações direcionados explicitamente ao público não acadêmico (ORTHIA, 2016). Tais ações tiveram sua origem anexa à pesquisa nas diversas ciências naturais, sendo que seus planejamento, produção e execução eram majoritariamente realizados pelos próprios cientistas dessas áreas. Nessa época, prevalecia um tom patriarcal e pedagógico na maioria das ações de divulgação, ou seja, a principal motivação estava em disseminar os diversos conhecimentos construídos pelos indivíduos, grupos e instituições que compõem o corpo acadêmico e científico.

Bucchi (2008) discorre sobre como o desenvolvimento de perspectivas multidisciplinares nas pesquisas em DC durante o século XIX trouxe à tona outros olhares de diferentes áreas de conhecimento, em especial as ciências sociais e humanas, e o desenvolvimento de críticas ao modelo de déficit ao longo do século XX. Com base nesse movimento de aproximação entre as práticas de divulgação (ou comunicação) da ciência com os campos teóricos que estudam as relações sociais e humanas surgem novos objetivos e questões para a Divulgação Científica. Se antes a principal (e talvez única) questão era a popularização de determinados conhecimentos construídos pelo meio acadêmico, a contribuição das ciências sociais e humanas possibilitou uma ampliação da área para questões como: Qual a visão que a população não acadêmica possui da ciência? Quais representações da ciência são veiculadas por meio dessas práticas? Qual o papel da Divulgação Científica na construção de identidades dentro e fora do meio acadêmico? A Divulgação Científica pode promover a democracia? 
Por meio dessa aproximação com as áreas das ciências sociais e humanas, surgem novos olhares para a DC, com caráter multidisciplinar. Apesar de já haver críticas a um modelo mais paternalista de Divulgação Científica antes do estabelecimento da área de DC enquanto campo teórico (TRENCH, 2006), essa mudança de perspectiva deu luz a discussões sobre a forma como a DC realiza suas práticas e quais as concepções de comunicação envolvidas. Nesse panorama, torna-se possível o reconhecimento dos acertos e falhas de um modelo transmissional do conhecimento e novas propostas mais dialógicas e participativas ganham espaço para emergirem dentro do campo.

Como tentativa de ilustrar esse conteúdo, Trench (2008) relaciona diferentes modelos comunicativos com os três modelos mais utilizados nas pesquisas que buscam compreender a Divulgação Científica: déficit, dialógico e participativo, bem como suas ênfases, objetivos e contextos.

Dentro do modelo de déficit, estão os modelos comunicativos que são de transferência/popularização de conteúdos, direcionais e pontuais, cuja ênfase está no conteúdo. Dentro desse contexto cientificista e tecnocrático, o objetivo principal é a transferência do conteúdo científico, sem adaptações e contextualizações para o público receptor.

No modelo dialógico, existem as consultas, negociações, ações interativas e de mãodupla, com ênfase no contexto em que essa prática ocorrerá. Um dos principais objetivos é promover a discussão das implicações da pesquisa científica, dentro de um contexto da responsabilidade social e da ciência como parte da cultura.

Por fim, no modelo participativo estão ações de coprodução de conhecimento, multidirecionais e com questões abertas a mudanças. Dentro dessa proposta, um dos principais objetivos é o estabelecimento de um conjunto de objetivos e agenda para a pesquisa voltada à promoção da democracia e de uma ciência preocupada com questões civis. Assim, a ênfase da ação está tanto no conteúdo quanto no contexto em que este é veiculado.

Além dos conteúdos e dos contextos, outros elementos também se mostram importantes na área. Segundo Davies e Horst (2016), a DC possui pelo menos três níveis de importância social: (1) promover o bem-estar de indivíduos, nações e organizações; (2) possibilitar a democracia por meio da conexão sólida entre os cidadãos e os conhecimentos científicos, bem como os modos como são construídos, suas limitações e consequências e (3) construir-se como forma de cultura e identidade, estando interligada a organizações, espaços, emoções, carreiras, 
futuros e muitos outros aspectos da vida social. Tal concepção traz à luz facetas antes pouco exploradas da DC, sendo o terceiro nível (cultura e identidade) o de maior destaque para essa dissertação, por possibilitar compreensões para além da dimensão de aprendizagem ou aproximação com conteúdos, processos e características das ciências. Assim, os processos de produção, veiculação e consumo da DC passam a ter valor, constituindo-se como uma ação em si, não definida somente a partir de seus produtos. Além disso, a prática de divulgar a ciência atribui identidades, significados e emoções, transformando também os atores envolvidos em todas as suas dimensões (como em sua produção) e não somente em seu consumo. Para além dos resultados, conhecimentos e produtos construídos nas mais diversas ciências, as ações de Divulgação Científica podem construir e compartilhar diversas representações dentro e fora da comunidade científica, sendo uma ferramenta para reafirmar relações sociais e identidades. Dessa forma, considera-se a DC enquanto um fenômeno cultural (DAVIES; HORST, 2016).

Frente ao entendimento da DC enquanto parte da cultura, cabe refletir sobre o acesso e a participação social nesta dimensão cultural. A seguir, serão discutidas diferentes concepções de Divulgação Científica participativa, baseando-se em propostas encontradas na literatura, para então relacioná-las com aspectos culturais centrais da Divulgação Científica, como a representação e a formação de identidade. 


\subsection{Divulgação científica participatória}

Uma tendência atual dentro do campo teórico da Divulgação Científica tem focado em ações participativas, visando o envolvimento da população nas tomadas de decisão e em debates com temas sociocientíficos. Documentos internacionais como a Declaração do Rio sobre Meio Ambiente e Desenvolvimento (ONU, 1992) e o Protocolo de Cartagena sobre Biossegurança da Convenção sobre Diversidade Biológica (CDB, 2019) têm indicado a necessidade de engajar a população nas tomadas de decisões, especialmente no que diz respeito às questões ambientais (EINSIEDEL, 2006), indo ao encontro dos objetivos desse modelo de DC. A participação social, entretanto, tem sido debatida não somente nas relações ciência/sociedade, mas também em outras áreas de conhecimento. Rock e colaboradores (2018) discorrem sobre quais as aproximações possíveis entre diferentes perspectivas de cocriação/participação e áreas como Marketing, Sociologia e Design, com os modelos participativos e participatórios no campo da Museologia e da Ciência. Apesar dos autores usarem diferentes perspectivas teóricas para realizar essas aproximações, será ressaltado o uso do modelo de "escada de participação cidadã”, proposto por Sherry Arnstein em 1969 (Figura 1).

Figura 1. Escada de Participação Cidadã (ARNSTEIN, 1969).

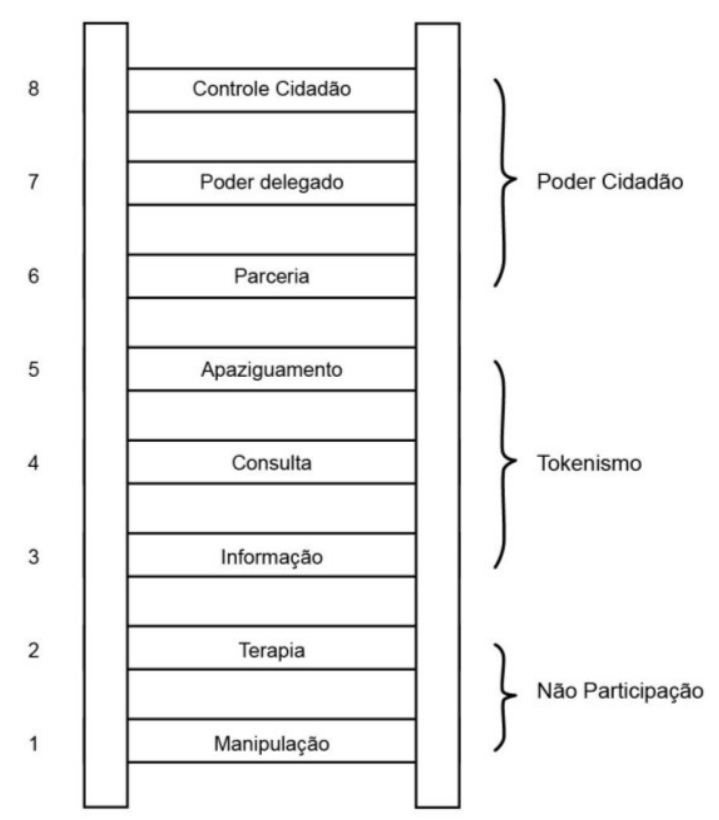

Fonte: Adaptado de Arnstein, 1969 (tradução nossa).

Segundo a autora, a participação cidadã é o pilar democrático em que há "participação dos governados em seu governo" (ARNSTEIN, 1969, p. 216, tradução nossa) e pode ser 
categorizado em oito estágios (ou degraus) que variam em um gradiente entre a nãoparticipação e o controle total por parte dos cidadãos. Na busca de uma forma de analisar essa questão, a autora propõe o modelo em forma de escada no qual os degraus representam níveis de participação. Os dois primeiros degraus (manipulação e terapia) representam níveis de nãoparticipação, ou seja, em que não há participação efetiva dos cidadãos e sim uma ferramenta para instruí-los sobre o que os governantes decidiram. Do terceiro ao quinto degrau (informação, consulta e apaziguamento), representantes do tokenismo ${ }^{10}$, há algum nível de participação dos cidadãos, porém sem influência real nas tomadas de decisão. Por fim, nos degraus mais altos (parceria, poder delegado e controle cidadão), há ações que de fato promovem o poder aos cidadãos tendo como ápice o controle direto dos cidadãos nas tomadas de decisão.

O uso do modelo como uma forma de aproximação teórica em pesquisas sobre participação em diferentes áreas se faz pertinente por dois motivos: (1) por ser conhecido e utilizado em diversas discussões e documentos, como o Relatório "Civic Engagement in Public Governance", publicado pela Organização das Nações Unidas (ONU, 2008), que buscam promover a participação social nas tomadas de decisão e no "Putting Rio Principle 10 Into Action: An Implementation Guide” do Programa Ambiental das Nações Unidas (UNEP, 2015), que propõe esse modelo como uma abordagem estratégica para a participação do público na tomada de decisão em questões ambientais e; (2) estar diretamente relacionado com o tema da Participação Infantil e ter sido utilizado também como base para proposições teóricas e discussões presentes em documentos como a "Convenção internacional sobre os direitos da criança” (ONU, 1989) e o "Children's Participation: From tokenism to citizenship" publicado pelo Fundo das Nações Unidas para a Infância (HART, 1992). Essa aproximação se mostra valiosa para o tema dessa dissertação, uma vez que o uso de uma metodologia compartilhada permite localizar possíveis similaridades e diferenças entre as áreas da DC participativa e a Participação Infantil. Entretanto, tal aproximação deve ser feita de forma cuidadosa e, apesar de sua potencial contribuição, serão apresentadas, posteriormente, reflexões e críticas sobre as concepções envolvidas no formato de escada apresentado pelo modelo.

Burgess e Chilvers (2006) discorrem sobre o panorama de ações de DC no Reino Unido, levantando que grande parte dos pesquisadores da área propõe modelos com três a quatro níveis

\footnotetext{
${ }^{10} \mathrm{O}$ termo tem origem na língua inglesa como uma variação do termo token, que tem como um dos significados um objeto ou sinal que possui valor simbólico sem que necessariamente possua um valor real.
} 
de participação/engajamento de maneira semelhante ao modelo de escada proposto por Arnstein. Para tentar fortalecer o debate em relação ao Modelo de Participação Cidadã, os autores sugerem uma divisão em duas categorias-chave para analisar as práticas comunicativas: o nível de engajamento dos envolvidos (identificados como educacional/provisão de informações; consulta e/ou diálogo/deliberação) e a representação baseada no conhecimento, assumindo-se que "os processos diferem em relação a quem está envolvido (experts, profissionais interessados, pessoas locais interessadas ou membros do público que não serão diretamente afetadas)" (p. 719, tradução nossa).

Em outra perspectiva, Metcalfe (2019) investigou 515 ações de Divulgação Científica que foram promovidas ao longo de 20 anos na Austrália e comparou com os referenciais e proposições teóricas dos três modelos mais reconhecidos de comunicação da ciência: déficit, dialógico e participativo. Em seu estudo encontrou que a Divulgação Científica participativa pode ser dividida em três principais formatos: (1) o público leigo participa em alguma ação juntamente com cientistas; (2) o público leigo coleta dados para cientistas ou realizam pesquisa científica e; (3) público leigo e cientistas constroem um novo tipo de conhecimento ou produto. Essa divisão é interessante pois explicita o quanto a participação do público leigo interfere no resultado final, ou seja, nos produtos e/ou conhecimentos. Nos dois primeiros formatos, há a participação pública em ações que possuem como fim um olhar voltado às ciências, sendo ações dentro de um processo que valoriza principalmente o conhecimento científico. Já no terceiro, os envolvidos estão abertos à produção conjunta de novos tipos de produtos e conhecimentos que levam como base tanto o conhecimento científico quanto o conhecimento leigo.

Ainda que a autora não o tenha feito no texto original, pode-se traçar paralelos entre essa divisão e alguns degraus do modelo de Arnstein (1969). No formato em que o público leigo participa em alguma ação, pode-se enquadrar a ação nos degraus de informação e/ou consulta, por possibilitar a participação da população leiga por meio da provisão de informação e, no caso do quarto degrau, consultando sua opinião (ARNSTEIN, 1969). Em alguns casos, como a cobrança de determinadas ações e/ou posicionamentos de instituições por meio das redes sociais, pode-se enquadrá-la também como uma forma de apaziguamento pois possibilita a fiscalização por parte do público leigo, mas não assegura mudanças, ficando a cargo das instituições o julgamento final (ARNSTEIN, 1969). Já no segundo formato, em que o público leigo coleta dados ou realizam pesquisa científica, pode-se enquadrar tanto enquanto uma forma de apaziguamento quando de parceria, a depender da participação do público leigo nos 
planejamentos e tomadas de decisão (ARNSTEIN, 1969). Por fim, na cocriação de produtos e conhecimentos podem-se enquadrar práticas de parceria, pois há a participação efetiva nos processos de tomada de decisão, e de poder delegado, caso a maior parte dos processos decisórios esteja sob responsabilidade do público leigo (ARNSTEIN, 1969).

Um ponto importante deve ser levantado ao se traçar tal paralelo: a ausência total do nível mais alto de participação do modelo de Arnstein (controle cidadão) em ações de Divulgação Científica. Como o modelo foi proposto dentro da área de gestão pública, é esperado que ocorram modificações ao serem adaptados a outros contextos. No caso de uma gestão democrática, um estágio máximo de participação que envolva o controle total por parte da comunidade possibilita a gestão financeira e negociações diretamente com os atores externos $^{11}$. Entretanto, ao transpor o modelo para a DC, é necessário refletir sobre a diferença entre dinâmicas da relação da comunidade acadêmica na sociedade e das discussões em gestão pública. Distinto da relação entre comunidade e tomadores de decisão, a diferença entre os agentes envolvidos na DC se dá em outros níveis, como a identidade do que é ou não ser cientista ou promotor de ações de DC (discussão a ser aprofundada nos itens seguintes). De maneira paradoxal, em um cenário em que as recentes discussões valorizam a promoção de ações participativas, caso tais ações atinjam os níveis mais altos de participação do público leigo segundo o modelo de Arnstein, ou a própria prática não seria mais caracterizada enquanto Divulgação Científica por ausência do setor científico ou o público leigo se transformaria nessa relação, se especializando o suficiente para ser considerado responsável pela prática científica.

Para compreender quais práticas e concepções têm sido descritas como Divulgação Científica participativa, foi realizada uma busca sistemática em três base de dados (ERIC, Scielo e Web of Science) com os termos "Divulgação Científica/science communication" e “participação/participatório/participation/participatory”. Após a retirada de textos distantes do tema em análise e resultados duplicados, foi obtido o número final de 126 publicações sobre Divulgação Científica e participação. Com a leitura dos resumos, foi feita uma primeira divisão entre três naturezas principais de trabalhos: (1) os editoriais/comentários; (2); as publicações que propõem principalmente um ensaio teórico para a área e/ou revisões; (3) aqueles baseados em experiências empíricas ou práticas de Divulgação Científica específicas.

\footnotetext{
${ }^{11}$ Para exemplos bem-sucedidos cf Arnstein (1969), ver p. 223-224.
} 
Além do tipo de pesquisa apresentado nas publicações, é possível observar também como aparecem as diferentes práticas de Divulgação Científica participativa e suas formas de interação entre o público acadêmico e não acadêmico. Diversos exemplos de ações de DC participativas foram encontrados e enquadrados dentro da perspectiva proposta por Metcalfe (2019). Dentre as ações em que o público participa juntamente com cientistas, é possível observar a participação em eventos, exposições, cafés científicos e interações pela internet em fóruns e redes sociais. Nas práticas em que o público leigo coleta dados ou realiza pesquisas, estão concentradas principalmente as ações de ciência cidadã/ciência aberta. Já no terceiro nível, foi possível localizar dois diferentes grupos em que há a construção conjunta de novos conhecimentos e produtos pelo público leigo e comunidade acadêmica: um voltado para as políticas públicas para a promoção de bem-estar ou discussão de problemas sociocientíficos e outro voltado para produção criativa. Sendo esse último grupo bastante relevante para esta pesquisa, procurou-se detalhar quais e como as ações participativas dessa natureza estão sendo abordadas pela literatura.

Durante o levantamento, foram encontradas, dentre outras práticas, aquelas voltadas à construção coletiva de narrativas como forma de trabalhar conteúdos sociocientíficos, imaginando futuros possíveis e avaliando os impactos de projetos de ciência cidadã (REINSBOROUGH, 2017; CONSTANT; ROBERTS, 2017). Ações envolvendo profissionais da área de comunicação, arte e design também se mostraram presentes, propondo a criação de novas estratégias multidisciplinares para a comunicação de temas científicos (ROCK et al., 2018; MEURK et al., 2015; LEHR et al., 2007; VERVOOT et al., 2014).

Essas práticas analisadas são ainda relevantes por transporem a restrição em geral colocada à participação da comunidade externa: a de se dar apenas no âmbito do consumo. Para além de consumidores participantes das ações idealizadas pela comunidade acadêmica, podese observar, nessa concepção, a delegação do poder aos participantes leigos para, além de serem os alvos das ações, também se tornarem os produtores. Para compreender como se articulam essas diferentes facetas do processo de Divulgação Científica é necessário a expansão do olhar para esse fenômeno comunicativo.

Assim, o item a seguir será dedicado à análise desse processo sob a ótica dos Estudos Culturais (DAVIES; HORST, 2016) e suas implicações nos entendimentos sobre os processos de regulação e consumo na Divulgação Científica. Especialmente, serão tratados os âmbitos da produção, representação e identidade, temas centrais desta dissertação. 


\subsection{Divulgação Científica enquanto cultura}

Os estudos com a perspectiva da DC enquanto fenômeno cultural são recentes e ainda há relativamente poucas publicações nessa interface entre a DC e os Estudos Culturais. Na base de dados Web of Science, a busca pelos termos " science communication" culture' localizou 144 resultados de 2003 a 2019, com notável crescimento de trabalhos a partir do ano de 2012 e com o ápice em 2017, com 24 publicações na área. Para essa pesquisa, foi tomado como base os pressupostos da área apresentados por Horst e Davies (2016).

Davies e Horst (2016) consideraram a ferramenta teórico-metodológica do circuito da cultura (ou circuito cultural) proposto por Paul du Gay e colaboradores (1997) como uma possibilidade de análise de DC, com aporte nos Estudos Culturais. Essa abordagem auxilia na compreensão das múltiplas dimensões envolvidas no processo de criação, compartilhamento e atribuição de sentidos e significados relativos aos processos de produção e consumo de representações e suas influências na construção de identidades na sociedade contemporânea, pós-industrial. Dentro desse referencial, entende-se que cultura é um conceito polissêmico, em constante construção, ou seja, não possui um significado único. Entretanto, para iniciar uma proposta, e assim conseguir colocar em prática a ferramenta analítica do circuito da cultura, os autores defendem dois significados complementares ao termo cultura: (1) enquanto produto ou 'todo modo de vida' e (2) como um processo de produção e circulação de significados (DU GAY et al., 1997). Essa discussão propõe que a cultura é uma esfera relacionada com a sociedade, mas não apenas um reflexo dela. Em teorias sociológicas convencionais, as culturas são compreendidas apenas como uma consequência das ações e normas sociais, enquanto que para os Estudos Culturais, a cultura é também um elemento formador e transformador das relações sociais (DU GAY et al., 1997).

Para Davies e Horst (2016), a Divulgação Científica é um fenômeno formado por diversos tipos de ações, tal como um ecossistema possui nichos ${ }^{12}$ com características diferentes, mas que são mutáveis e se complementam. Para ilustrar a analogia, listam quatro atividades que poderiam se enquadrar em nichos, tais como: (1) mídia: jornalismo, internet, redes sociais, entre

\footnotetext{
${ }^{12} \mathrm{Na}$ Biologia e mais especificamente na Ecologia, um ecossistema é composto por diversas populações de organismos (comunidades) somados às condições do ambiente (umidade, temperatura, acidez do solo, entre outros). Já os nichos são as variáveis do ambiente que são necessárias para a sobrevivência de determinada espécie, podendo se sobrepor gerando uma coexistência (por exemplo, as aves sabiá-laranjeira e joão-de-barro coexistem na região urbana de São Paulo, vivendo em locais semelhantes) mas com pequenas diferenças (ambos se alimentam de pequenos invertebrados, mas o sabiá-laranjeira se alimenta também de frutas).
} 
outros; (2) livros escritos por um (a) cientista; (3) promoção estatal de informações: campanhas de saúde, sustentabilidade, energia, entre outros e (4) museus e centros de ciências.

Além disso, para as autoras, as atividades de DC vão muito além da transmissão e recepção de conteúdos e processos científicos, estando em jogo diversos valores, como a construção de identidades, solidificação de relações sociais e engajamento em debates políticos. Assim, pode-se considerar a ação de divulgar ciência como um fenômeno cultural dentro da perspectiva dos Estudos Culturais de Paul du Gay e colaboradores (1997).

Para a estrutura central desse argumento, analisam o estudo de caso do evento Science in the City ${ }^{13}$, que ocorreu paralelamente ao Euroscience Open Forum ${ }^{14}$ (ESOF), na cidade de Copenhagen, capital da Dinamarca, em 2014, sendo ambos eventos abertos ao público e pautados em temas científicos mas com objetivos diferentes. Enquanto o ESOF possui o formato de encontro em que são debatidos temas científicos, o Science in the City tem a estrutura de um festival de ciência com o objetivo central de promover ações dedicadas a pessoas de todas as idades que são curiosas por temas científicos e tecnológicos ${ }^{15}$. Utilizando a ferramenta do circuito da cultura, discorrem sobre como os processos de divulgar e engajar o público com temas científicos nesses dois eventos podem ser analisados sob a ótica de suas representações, identidades, produção, consumo e regulação. Essas dimensões formam um ciclo não linear, passível de mudanças de sentido (Figura 2), mas que se torna coeso ao se considerar todas as dimensões.

\footnotetext{
${ }^{13}$ Ciência na Cidade, em tradução livre.

${ }^{14}$ Fórum Aberto de Ciência Europeia, em tradução livre.

${ }^{15}$ Disponível em $<$ https://www.esof.eu/en/programmes/science-in-the-city-festival.html $>$, acesso em 15 out 2019.
} 
Figura 2. Esquema de circuito da cultura (DU GAY et al., 1997).

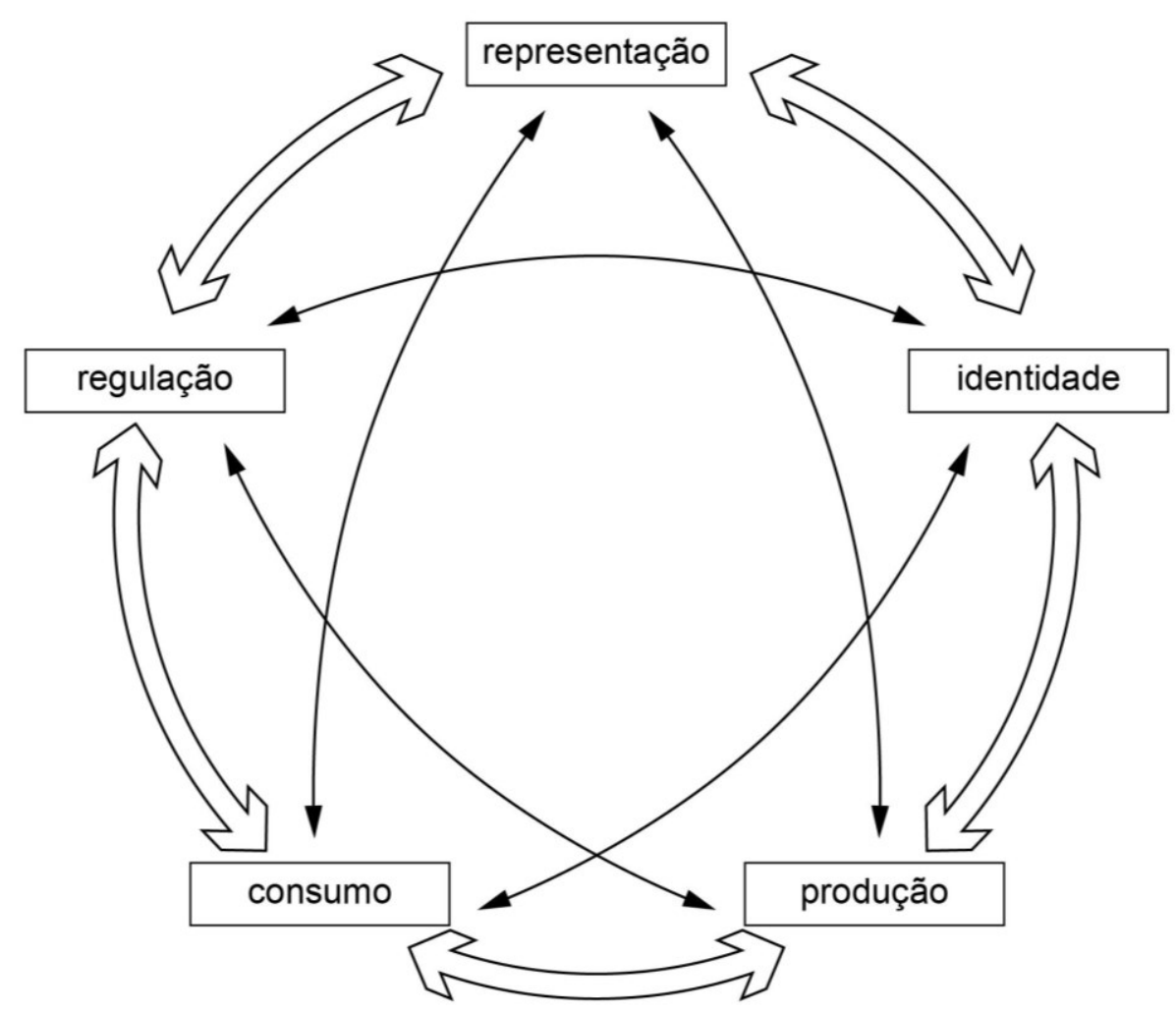

Fonte: Adaptado de Du Gay et al., 1997 (tradução nossa).

O esquema acima, proposto por du Gay e colaboradores (1997), emergiu de suas análises sobre o fenômeno cultural causado pelo lançamento do aparelho Sony Walkman e sua popularização na década de 1980. Segundo os autores, o Walkman se tornou um objeto cultural em nossa sociedade por ter sido construído por meio de um conjunto de significados e práticas. Isso inclui não somente a construção técnica do aparelho, mas também dos sentidos mais abstratos que lhe são atribuídos. Neste trabalho, os autores apresentaram cada dimensão separadamente, bem como suas relações com os outros processos do circuito.

O circuito da cultura é constituído das representações que o Walkman sofre no processo publicitário por meio das propagandas e das mídias. Por meio de diversos cartazes e informes de apresentação do produto, é possível observar que o aparelho foi intencionalmente relacionado a significados como mobilidade, esporte, atividade física, lazer e juventude. Com isso, essas ações ajudam a criar e reforçar as identidades dos consumidores desse produto, influenciando para essa dimensão do circuito. Não é esperado que apenas jovens esportistas comprem um Walkman, assim como não é esperado que quem compre passe a ter hábitos mais 
saudáveis e que passem a apreciar uma maior mobilidade. Ainda assim, as vendas de Walkman foram majoritariamente a um público jovem, e a imagem de ouvir música em qualquer local, por exemplo em um vagão de trem, fez parte da identidade de ser jovem durante essa época. Essa representação atua de maneira dialética com o mundo social do usuário do Walkman: não é somente um reflexo, assim como não é impositivo ao seu público.

Em um terceiro momento da análise, buscam as origens narrativas para a produção do Walkman, descobrindo uma multiplicidade de explicações vinda de diversos atores internos da empresa japonesa Sony. Após a concepção dessa ideia, o projeto passa por uma etapa de tornála vendável, de interligar produção e consumo. Essa ligação foi estudada em quatro momentos: (1) a criação do produto direcionada a um público jovem imaginário, (2) na escolha do nome para o aparelho, (3) nas ações de marketing e (4) nas ações da Sony para monitorar o feedback de seus consumidores. Além disso, essa articulação produção-consumo foi analisada também no caminho oposto ao tradicional, atentando a como o consumo influencia a produção. Nesse caso, para Du Gay e colaboradores, os designers do Walkman agem como "intermediários de cultura”, agregando significados simbólicos (mobilidade, esporte, atividade fisica, lazer e juventude) a esse objeto (o Sony Walkman) e seu consumo.

Por fim, trata da regulação de normas e atitudes culturais durante o auge do Walkman. É notável que, ao longo das décadas que o precederam, houve um declínio da esfera pública e um aumento da privatização cultural, sendo o aparelho estéreo portátil uma das últimas inovações tecnológicas que fizeram parte dessa tendência. Entretanto, ao mesmo tempo que representa um consumo cultural privado (músicas são ouvidas individualmente), ele transpõe à esfera pública a ação privada de ouvir música, que antes ocorria em locais como casas, carros, entre outros. Apesar desta característica libertadora, o uso de Walkman foi motivo de preocupação por induzir comportamentos antissociais. Em resposta a essa regulação, os fones de ouvido que acompanhavam o aparelho, que antes cobriam boa parte do ouvido externo, reduziram tanto em tamanho quanto em volume sonoro emitido, transformando novamente as dimensões deste circuito.

\subsubsection{Circuito da Cultura na Divulgação Científica}

Davies e Horst (2016) observaram que tanto no festival Science in the City quanto nas tendas de exposição do ESOF de 2014, foram encontradas diferentes representações das 
universidades, agências de fomento, empresas e outras organizações científicas presentes. Um fator interessante é que as representações de uma mesma organização se mostraram diferentes dependendo de onde estavam expostas. No Science in the City, festival cujo público era voltado para a população não acadêmica, a principal representação era no tipo de ciência que a organização fazia, enquanto no ESOF, fórum voltado para discussões e políticas da comunidade científica, a principal representação era voltada para a gestão da marca das organizações. Revelam-se assim as múltiplas representações que uma mesma organização pode valorizar a depender da ação a ser feita, do público, do meio e de tanto fatores envolvidos. Sendo assim, é possível inferir as possibilidades de representação que as atividades de DC podem produzir, como as visões de cientista e de ciência veiculadas, como se dão os processos de construção desses conhecimentos, entre outros.

No campo da produção, diversos fatores também influenciam a prática da DC. Muitas universidades e organizações de pesquisa veem no ESOF um local para falar sobre seus estudos de caso que obtiveram resultados positivos, como forma de promover suas relações públicas, atrair investimentos e ganhar visibilidade perante a população. Como as autoras defendem, a DC pode ser usada como parte de um esforço que as organizações fazem para atingir uma boa imagem pública. Essa imagem pautada em casos de construção de conhecimentos científícos e da resolução de problemas através do desenvolvimento de tecnologia pode ser muito valioso para qualquer organização por atrair investimentos e/ou atenção da população. Devido a essa importância nas relações públicas, a DC tem se mostrado uma prática cada vez mais especializada, tendo equipes e investimento voltados para isso e não dependendo mais de ações individuais de cientistas em seu tempo livre para sua produção. Atualmente, no contexto europeu (no qual as autoras se baseiam), a DC tem sido considerada parte do processo de produção e não mais uma forma de reportar um resultado científicos. Em contextos em que há maior aporte de recursos da iniciativa privada, se mostra necessário divulgar os resultados para atrair os recursos necessários para pesquisar.

O consumo na DC (e em outros fenômenos culturais) não ocorre de maneira passiva e desprovida de sentido. Pelo contrário, é decodificado de acordo com os valores, preferências e interesses do público, por vezes sendo consumido de maneira bem diferente ao esperado pelos produtores. Por exemplo, se um assunto for considerado irrelevante pelo visitante do festival, ele pode se dirigir a outro estande, participar de maneira não esperada (não obedecendo procedimentos e comandos) ou simplesmente ir embora. Essas respostas não devem ser vistas 
apenas como um fracasso, mas sim como sinais do que pode ser melhorado e quais novas abordagens podem ser feitas. O consumo está muito relacionado com as emoções dos participantes e exerce também um importante papel na formação de identidades. Cidadãoscientistas, por exemplo, podem formar uma percepção diferenciada sobre o próprio engajamento em questões políticas de ciência.

Diversos são os níveis de regulação da DC, considerando-se o conjunto de normas formais e informais que podem influenciar essa atividade na sociedade. Exigência por ações de divulgação em projetos financiados por agências de fomento é uma regulação de nível oficial que é aplicada e influencia em sua produção. Entretanto, diversas outras normas que não são explicitadas formalmente também podem influenciar as ações de DC. As diferentes visões e concepções de ciência ao longo da história podem alterar a forma como a divulgação é feita, favorecendo-a ou não, a depender de como é vista dentro do meio acadêmico.

Em suas considerações, as autoras ressaltam que as identidades formadas e transformadas ao longo das ações de DC podem influenciar nas formas que se produzem, consomem, regulam e representam. Como explicado nas questões da representação e da produção, a depender do local, os focos das organizações podem ser diferentes, desde passar uma boa imagem de sua instituição até exibir conhecimentos científicos de maneira descontraída, ou ainda a espetacularização e aplicação a questões cotidianas. Para as autoras,

(...) quando cientistas divulgam, não estão apenas apresentando fatos ou informações, mas também atribuindo sentido ao que a ciência é e deveria ser, gerenciando suas identidades profissional e pessoal (DAVIES; HORST, 2016, p. 14)

Para complementar essa discussão das influências de cada dimensão sob as demais, o processo de transformação de identidades ocorre também no nível do espectador, do consumidor. Diferentes formas de consumir os materiais de DC podem ser frutos da (ou contribuírem para a) formação de identidades, da forma como as pessoas se enxergam enquanto cidadãs e como veem as comunidades de que fazem parte.

Dessas interações entre representação, identidade e produção, em conjunto com as discussões sobre as culturas da infância e formas de Participação Infantil, essa pesquisa se propõe a investigar como a participação de crianças no processo de criação de materiais de DC podem auxiliar na (trans) formação de identidades, tanto das crianças quanto dos adultos 
(produtores), buscando aprimorar as relações entre projetos de conservação e as comunidades que estão inseridos.

Foram assumidos esses referenciais e é importante esclarecer que, embora a defesa de Horst e Davies (2016) de divulgação enquanto cultura se paute fortemente na produção por parte, quase exclusiva, das comunidades acadêmica e jornalística, nas concepções mais recentes dos estudos sociais da infância, as crianças têm sido vistas como ativas produtoras de cultura, ressignificando o mundo adulto de maneira interpretativa, compreendendo-o ao mesmo tempo que o transforma para o seu universo (CORSARO, 2011). Assim, percebe-se que colocar em diálogo a Divulgação Científica e a Participação Infantil, tendo os Estudos Culturais como elemento tecidual, promove um conjunto de desafios ao pesquisador. Promover ações comunicacionais em C\&T com altos níveis de participação é possível, como foi visto nos itens anteriores com exemplos de cocriação de produtos e conhecimentos em diversas temáticas. Entretanto, quando o tema é direcionado ao público infantil, o cenário é outro: apesar de haver registros de práticas consultivas ou de crianças participando de ações planejadas por adultos, não foi localizado nas bases de dados um número relevante de ações participativas com níveis de criação conjunta de produtos e/ou conhecimentos novos.

Nessa perspectiva, esta pesquisa focou em uma prática de cocriação de produtos junto a crianças, com foco no processo de produção suas influências nas demais dimensões do circuito da cultura. Para melhor compreender como se dão os processos participatórios de produção, em especial de novas mídias, será introduzido o conceito de mídia participatória. 


\subsection{Cultura participatória e alfabetização em novas mídias}

O professor e pesquisador do programa de Estudos de Mídias Comparadas do Massachusetts Institute of Technology (MIT) Henry Jenkins e colaboradores definem uma cultura participatória como:

(...) uma cultura com barreiras relativamente baixas para a expressão artística e engajamento cívico, forte apoio à criação e compartilhamento de criações e algum tipo de orientação informal pela qual o que é conhecido pelos mais experientes é repassado aos novatos. Uma cultura participatória também é uma em que os membros acreditam que suas contribuições são importantes e sentem algum grau de conexão social uns com os outros (ao menos eles se importam com o que as outras pessoas pensam sobre o que criaram). (JENKINS et al., 2006, p. 3, tradução nossa).

Nos Estudos de Mídia, sua concepção contrasta com a clássica ideia (difundida com a popularização dos meios de comunicação de massa) de que ocorre um consumo de mídias de maneira passiva por parte dos seus espectadores. Esse discurso está em sintonia com os Estudos Culturais e as concepções de Participação Infantil discutidas nos capítulos anteriores e todos abrangem um pressuposto importante para essa dissertação: o consumo de artefatos culturais (seja de natureza científica, cultura de massa ou do mundo dos adultos) não se dá de maneira passiva e transmissional. Assim, a interação entre os indivíduos e seus meios é capaz de produzir novos sentidos e significados. Jenkins e colaboradores (2006) também defendem que as novas gerações devem ter uma alfabetização em novas mídias, ferramentas capazes de promover tal cultura participatória. Porém, defende que a alfabetização textual ainda deve ser prioridade. Segundo o autor:

\footnotetext{
Antes que os alunos possam se envolver com a nova cultura, eles devem ser capazes de ler e escrever. Assim como o surgimento da linguagem escrita mudou as tradições orais e o surgimento de textos impressos mudou nossa relação com a linguagem escrita, o surgimento de novos modos digitais de expressão muda nossa relação com os textos impressos (JENKINS et al., 2006, p. 19, tradução nossa).
}

Por ter um foco nas novas mídias, em especial no uso do meio digital e da internet, o autor propõe três problemas como sendo centrais nesse movimento de alfabetização. O primeiro se baseia na lacuna de participação causada pela diferença de acesso às novas mídias. $\mathrm{O}$ segundo tem relação com a transparência, ou seja, o quanto "as crianças estão refletindo ativamente sobre suas experiências de mídia e podem articular o que aprendem com sua participação" (JENKINS et al., 2006, p. 12, tradução nossa). O terceiro envolve uma crença de que "as crianças, por conta própria, podem desenvolver as normas éticas necessárias para lidar 
com um ambiente social on-line complexo e diversificado (desafios éticos)" (JENKINS, et al., 2006, p. 12, tradução nossa). Somado aos desafios levantados nos capítulos anteriores, a promoção de práticas participatórias em DC podem abranger (em maior ou menor escala) essas três questões da alfabetização em novas mídias.

No que diz respeito à primeira problematização (lacuna de participação), das práticas encontradas nas bases de dados, envolvendo DC e Participação Infantil, uma quantidade considerável abrangia tecnologias novas e que envolvem acesso à internet, como a produção e publicação de vídeos e a interação nas redes sociais. O uso da internet como estratégia de promoção da participação pública em discussões de temas científicos e tecnológicos faz sentido uma vez que, segundo a última pesquisa de Percepção Pública da Ciência e Tecnologia, é a segunda fonte de maior acesso a esses temas, perdendo apenas para a televisão (MCTI, 2019). Segundo os dados da Pesquisa Nacional por Amostra de Domicílios Contínua (PNAD Contínua) de 2017 (IBGE, 2017), 69\% dos brasileiros acima de 10 anos têm acesso à internet, sendo um número relativamente alto quando comparado aos dados da mesma pesquisa realizada em anos anteriores. Apesar disso, quando é realizada análise dentro de diferentes grupos, os dados podem revelar grandes lacunas de acesso. Em relação ao nível de instrução, menos de $12 \%$ das pessoas sem instrução e pouco mais da metade das pessoas com Ensino Fundamental incompleto possuem acesso à internet. Outra variável que ilustra essa questão é a diferença de acesso em residências localizadas em zonas urbanas e rurais. Dos dados relativos a todo o território nacional, $80,1 \%$ dos domicílios em zona urbana possuem acesso à internet em comparação a $41 \%$ dos domicílios em zona rural. A depender da região essa discrepância pode aumentar: na região Norte a relação é de $80 \%$ das residências urbanas e $27,3 \%$ dos domicílios na zona rural. Ainda assim, apesar da internet ser uma fonte menos acessível a conteúdos científicos, é interessante pensá-la em suas possibilidades para além de suas limitações. Interações, ainda que restritas a níveis de consulta, são possíveis por meio dessa conexão entre produtores e consumidores. Nesse sentido, ainda que esteja enviesada em torno da população com maior acesso, é justamente por meio da consciência de sua limitação que o foco de novas ações participatórias podem ser propostas, focando no combate às desigualdades de acesso à informação e de participação.

Em relação à questão da transparência, a DC participatória envolve uma compreensão crítica da mídia utilizada como meio de comunicação. Quais as vantagens de se optar por determinadas mídias em função de outras? Dessa forma, segundo Jenkins e colaboradores 
(2006), ao longo das ações participatórias deve-se fornecer espaço para discussões sobre o formato, além do conteúdo. Nesse sentido, se aproxima de algumas reflexões realizadas neste capítulo, principalmente na concepção cultural da Divulgação Científica que busca ampliar a discussão para a produção e compartilhamento de significados em torno dos temas científicos (DAVIES; HORST, 2016). Como se dá a produção desses significados? O que eles representam em relação ao universo das ciências? Como o público os estão consumindo? Quem os regulam? Quais as identidades envolvidas? Todos esses pontos ajudam a ter uma perspectiva dos elementos que compõe a prática de divulgar temas científicos para além dos conteúdos conceituais envolvidos.

Por fim, os desafios éticos são presentes tanto nas áreas de Divulgação Científica participatória quanto dos estudos da Participação Infantil. Assim como a Divulgação Científica demanda, em algum nível, a participação da comunidade acadêmica, a promoção de uma cultura participatória demanda a presença de mediadores que sejam capazes de fazer essa relação entre as crianças e o mundo adulto, suas regras, normas e questões éticas. Como será discorrido a seguir, as crianças possuem uma dupla vulnerabilidade (inerente e estrutural) e deve-se buscar um balanço entre protegê-las e deixá-las sob os riscos da modernidade (SOARES, 2005). Assim, uma cultura participatória deve ter atenção constante em relação aos dilemas éticos envolvidos na área da comunicação. No caso da Divulgação Científica, diversas questões, como os temas controversos, também envolvem importantes discussões éticas e regulações tanto em ações voltadas às crianças quanto a outros públicos.

Com essas questões, ao invés de focar puramente na tecnologia como objeto de estudo, Jenkins (2006) traz à luz a relação entre comunidade e tecnologia, fazendo uma abordagem ecológica dessas novas mídias. A utilização das novas mídias na promoção de uma cultura participatória ainda é um fenômeno recente e tem sido foco de estudo de diversos casos no mundo. Ativismo online por meio das redes sociais (STORNAIUOLO; THOMAS, 2017), discussão de temas sociais por meio da produção de vídeos (SALVIO, 2013; ROYDS, 2015; POTTER, 2017) e de mídias sonoras (DREHER, 2012) são exemplos de como diversos grupos, em especial de crianças e jovens em diversos contextos sociais, estão usando essas novas mídias para conhecer, interagir e participar ativamente de comunidades. Nesse caso, um termo que sintetiza essa concepção é o de mídias participatórias, que será utilizado nesse trabalho. 


\subsubsection{Mídias participatórias e a construção de identidades}

O Centro de Pedagogia Urbana (CUP, uma organização sem fins lucrativos de Nova Iorque/Estados Unidos da América) propôs uma investigação em torno de um problema comum no Bronx: os desertos alimentares. A partir dessa questão foi montado um grupo formado por jovens locais, educadores e profissionais de diversas áreas para a produção de um curtametragem $^{16}$ que abordasse esse tema (SALVIO, 2013). O autor analisa o movimento proposto pelo CUP em relação à autenticidade da participação dos jovens.

A questão da participação é um paradoxo central em meu estudo sobre o CUP. No contexto da investigação urbana do CUP, aprendi que a autenticidade não está fundamentada em um projeto mútuo de formar uma questão para investigação, mas, ao mesmo tempo, o projeto mútuo de investigação é experimentado pelos participantes como autêntico. Eu suspeito que este seja o caso porque os participantes se comunicam sobre uma experiência mútua. (...) A questão, apesar de não ser proposta pelos alunos, surge dos bairros onde os estudantes moram. A questão em si está ligada aos objetos da cidade (SALVIO, 2013, p. 175176, tradução nossa, grifo da autora).

Assim, apesar da questão central do projeto não ter sido proposta diretamente pelos jovens participantes (e sim acordado previamente pelos educadores do CUP), o projeto foi vivido de forma autêntica por se referir a uma questão presente no local que os jovens vivem. Outro exemplo que envolve histórias locais sendo narradas de forma audiovisual é a plataforma Big Stories ${ }^{17}$. Com base na plataforma, Potter discorre que:

1. Os seres humanos moldam sua identidade de alguma forma narrativa em todas as culturas e, assim, contar histórias é central na descrição da experiência individual e coletiva.

2. Mídias participativas têm o potencial de criar uma cultura de mídia com mais nuances, ética, diversificada e democrática. (POTTER, 2017, p. 118 , tradução nossa)

De fato, as mídias participatórias com base na linguagem audiovisual parecem propícias para a construção e veiculação de identidades culturais, com poder para incluir grupos sociais cujas representações foram historicamente excluídas das mídias tradicionais e de massa (POTTER, 2017). Ao ter a possibilidade de fazer parte do processo de produção das mídias, as diferentes identidades em jogo devem dialogar por meio das escolhas de representações e imagens a serem veiculadas. Durante esse processo de contar estórias sobre si ou sobre os

\footnotetext{
${ }^{16}$ Disponível em < https://vimeo.com/7454224>, acesso em 31 jul 2019.

${ }^{17}$ Disponível em $<$ http://bigstories.com.au/>, acesso em 31 jul 2019.
} 
grupos aos quais pertencem, os participantes são confrontados quanto à imagem que possuem de si e do mundo a sua volta, promovendo a construção da identidade própria ou de seus grupos.

Outra relação entre identidade e mídias participatórias está na comunicação e encontro entre pessoas que se identificam dentro de um mesmo grupo, possibilitando um ativismo nos meios digitais. Stornaiuolo e Thomas (2017) investigam como adolescentes e jovens adultos se comportam em sites de mídias participatórias (em geral redes sociais). As autoras defendem que jovens, em especial os de grupos marginalizados, como LGBTQI+ e negros, estão usando as mídias digitais para encontrar formas de se "conectar uns com os outros, promover mudanças sociais e contra narrar o mundo a partir de sua perspectiva" (STORNAIUOLO; THOMAS, 2017, p. 338, tradução nossa). Ainda segundo as autoras, quanto à criação de novas narrativas, defende-se que

Questões de representação - como representamos os outros e como as pessoas se representam - estão no coração do ativismo digital da juventude. No passado recente, os jovens tinham poucas oportunidades de se representarem em larga escala, ao invés disso, contavam com a mídia de massa e instituições estabelecidas (por exemplo, educação, publicação, mídia de massa) para elaborar as histórias que dominavam nosso entendimento um do outro e de nós mesmos. As pessoas que eram marginalizadas e as minorias precisavam aderir às noções dominantes de participação cívica - noções que eram influenciadas por homens brancos, fisicamente capazes, cisgêneros e de classe média ou ricos. Hoje, no entanto, há novas possibilidades para restabelecer essas representações (STORNAIUOLO; THOMAS, 2017, p. 351, tradução nossa).

Assim, além do encontro dessas identidades marginalizadas, as redes sociais e outras mídias participatórias são capazes de promover novas possibilidades de representação e de entendimento de si e de outras pessoas.

$\mathrm{Na}$ Divulgação Científica, práticas com mídias participatórias podem auxiliar nas representações dos conhecimentos cotidianos, das Ciências Humanas e Naturais. Ainda, é relevante para essa pesquisa pensar em como a questão da representação está relacionada com o contexto local em que essas ações são propostas. A realização de práticas participatórias relacionadas a projetos de conservação in situ, trabalhos com comunidades tradicionais, ações educativas em periferias, entre outros, podem ter grande influência dos e nos costumes e tradições de um determinado local. Assim como os objetos e costumes do Bronx foram integrados ao curta-metragem "Bodega Down Bronx", o que proporcionou uma participação 
autêntica dos jovens da região (SALVIO, 2013), diversos podem ser os elementos das culturas locais a serem incorporados durante as ações educativas e práticas de DC participatória.

No caso de ações voltadas ao público infantil, essas representações também podem ter origem nos conhecimentos das crianças em relação ao tema científico, como suas explicações para fenômenos naturais, ou mesmo adquirindo aspectos morfológicos das culturas da infância como: estórias, cantigas, desenhos animados, jogos, entre outros (SARMENTO, 2004). No capítulo seguinte, será aprofundada a discussão em relação à produção cultural da infância, bem como suas contribuições à produção de mídias na DC. 


\section{Infância e a Divulgação Científica}

Analisando historicamente, a concepção de infância enquanto uma categoria humana com características próprias é um acontecimento recente na sociedade. Philippe Ariès (1986) discorre sobre a representação das crianças na arte, ainda no século XII, diferenciadas apenas pelo seu tamanho reduzido; nas pinturas, suas roupas, poses e semblantes apresentavam-se iguais aos dos adultos. É a partir do século XIII, entretanto, que se torna possível interpretar o início da emergência da ideia de infância, pelo menos na tentativa de representar as crianças com características próprias, enquanto seres diferentes dos adultos. Por meio do olhar da arte para as crianças, tanto visual quanto escrita, podem ser retomados os sentimentos dos artistas em relação a essa etapa da vida. Do papel central na composição da família a vidas praticamente descartáveis (nos períodos de alta mortalidade infantil), os retratos podem revelar muito de seu contexto histórico. Dessa observação, Ariès (1986) argumenta que as crianças foram objetos de paparicação ou de moralização ao decorrer da nossa história: ora a criança foi vista como "engraçadinha" (p. 58), superficialmente adorados durante um período curto, para depois se tornar um membro familiar como outro qualquer; ora foi enxergada como ser humano a ser moralizado e educado para o trabalho (ou, nas famílias mais ricas, para o cuidado dos bens herdados). Para Sarmento (2004), essas mudanças estiveram fortemente relacionadas com o desenvolvimento de um sistema educacional e de uma estrutura familiar burguesa com base na afeição. Em ambos os casos, a infância enquanto categoria geracional, era pouco representada nos meios sociais, tendo suas necessidades e direitos específicos rapidamente esquecidos quando adquiriam o mínimo de autonomia ou não existindo, sendo considerada apenas uma preparação ao mundo adulto.

No século XXI é observável a crescente tendência em proteger as crianças na sociedade contemporânea. Soares (2005) discute esse dilema entre a proteção e a Participação Infantil nas tomadas de decisão, tanto no âmbito coletivo quanto nas escolhas de sua própria vida. Segundo a autora, essa tensão é pautada na dupla natureza da vulnerabilidade das crianças: a vulnerabilidade inerente e a vulnerabilidade estrutural (LANDSDOWN, 1994 apud SOARES, 2005). A primeira refere-se à imaturidade biológica e psicológica das crianças, tornando-as inquestionavelmente dependentes dos adultos, enquanto a segunda trata da falta de poder político, econômico e de direitos civis das crianças, construída histórica e socialmente. Assim, a vulnerabilidade estrutural da infância é fruto das presunções que se têm em relação à natureza das crianças e suas relações com o meio social (SOARES, 2005). A autora ainda defende que 
dessa tensão emergem dois tipos de discursos: o discurso paternalista e o discurso emancipador. O primeiro foca na vulnerabilidade inerente das crianças, defendendo uma incapacidade de autonomia e racionalidade, atribuindo aos pais o direito de tomar decisões, mesmo que firam a liberdade de seus filhos. Já o discurso emancipador defende a capacidade das crianças de racionalidade e de fazer escolhas acertadas, explicitando a falha lógica da justificativa de impedir que crianças tomem decisões por falta de experiência, negando-lhes assim, a própria experiência. Essa concepção da capacidade de autonomia infantil não se contrapõe, tampouco nega, os direitos de provisão e proteção das crianças, sendo reconhecidos seus direitos a saúde, educação, segurança social, cuidados físicos, vida familiar, recreio, cultura e contra a discriminação, abuso, exploração, injustiça e conflito.

Por levar as ideias da autora em consideração para a promoção de pesquisas e práticas de DC, as vulnerabilidades das crianças se tornam elementos que permearão as decisões envolvidas no planejamento e execução de ações que visam a participação do público infantil. Da mesma forma que práticas demasiadamente simplificadas e com caráter paternalista não promovem a participação de crianças, ações que exigem além das possibilidades de espaço, tempo e das habilidades que crianças podem realizar sem auxílio de adultos também podem ser ineficientes.

Apesar de parecer um consenso que as ações participativas priorizem o discurso emancipador, se faz necessário questionar se há limitações ao se transpor esse discurso à Divulgação Científica voltada ao público infantil. Seguindo a discussão proposta no capítulo anterior, é possível que as crianças sejam participantes das ações de Divulgação Científica, atingindo modos autônomos de participação? No contexto desta pesquisa, buscou-se a promoção de ações com maior presença de um discurso emancipador, levando em conta as dificuldades de se garantir modos participatórios e autonomia das crianças. 


\subsection{Participação infantil}

A Participação Infantil é um termo que vem sendo amplamente utilizado para designar diferentes tipos de ações. Por ainda não ser consensual, Thomas (2007) faz um levantamento sobre as diversas concepções e uso do termo. Segundo o autor, a Participação Infantil pode ser relacionada tanto a um processo quanto a um produto, bem como pode estar relacionada com tomadas de decisões em âmbito coletivo ou individual. Para fomentar sua argumentação, discute alguns modelos de Participação Infantil, refletindo sobre suas diferentes intencionalidades e objetivos. Thomas (2007) analisa que em alguns modelos de Participação Infantil, o nível de consulta ${ }^{18}$ é considerado a parte, enquanto que em outros é entendido apenas como uma categoria dentro da participação. Segundo o autor, essas concepções de incluir ou não a consulta como um modo de participação varia enquanto os objetivos que se têm com a ação participativa, dentre eles: para empoderar e elevar habilidades das crianças, promover direitos das crianças e democracia, entre outros. Nesse sentido, a consulta a crianças pode promover seus direitos, mas não as empodera enquanto cidadãs em tomadas de decisão.

Esses objetivos ainda auxiliam nas estruturas presentes nos modelos de participação estudados por Thomas (2007). A escada de Participação Infantil de Hart (1992) foi adaptado do modelo de Arnstein (1969) e é o primeiro modelo proposto, constituído de 8 degraus: os não participativos (manipulação; decoração; tokenismo), níveis médios (atribuindo e comunicando; consultando e comunicando) e os participativos (iniciação pelos adultos, compartilhamento com crianças; iniciação e direção pelas crianças; e iniciação pelas crianças, compartilhamento com adultos). Diversas adaptações foram feitas ao modelo de Hart, incluindo degraus (e.g. adultos comandam; adultos comandam gentilmente) ou alterando o nível mais alto da escada. Para Franklin (1997 apud THOMAS, 2007), o nível maior de Participação Infantil deveria ser o controle totalmente centralizado nas mãos das crianças, propondo um gradiente entre a total falta de poder até o completo poder infantil. Em ambos os modelos, pressupõe-se que há um objetivo final na Participação Infantil, seja com o poder compartilhado entre crianças e adultos ou com o poder totalmente na mão das crianças.

Apesar de Hart (1992, p. 11, tradução nossa) explicitar em seu texto que a escada "não deve ser considerada como um palito medidor de qualidade de qualquer programa" e que "não é necessário que crianças sempre operem no degrau mais alto possível da escada”, seu modelo

\footnotetext{
${ }^{18}$ Nesse texto considerou a consulta como o nível em que as crianças "não participam do estágio em que as decisões são realmente feitas” (SHIER, 2001 p. 113-114, tradução nossa).
} 
é alvo de críticas. Segundo Thomas (2007), diversos autores criticam seu formato, pois, com uma escada hierarquizada, fica explícita ou implícita uma ideia de que há ações que promovem mais ou menos participação das crianças, com um ápice que deve ser o objetivo de qualquer ação participativa. Esse questionamento se torna válido uma vez que nem sempre uma ação poderá ser construída completamente e exclusivamente por crianças. No caso da educação infantil, por exemplo, a ausência de um educador pode ser vista com bons olhos em determinados momentos da rotina, como nas brincadeiras livres, mas também pode representar um problema quando a ação educativa demanda um adulto que estabeleça as relações entre o que está sendo experienciado no espaço escolar com diversos conhecimentos construídos historicamente pela humanidade. Assim, Treseder e Smith (1997) defendem uma nãohierarquização da Participação Infantil, pois diferentes ações e contextos demandam diferentes tipos de participação das crianças. Dessa forma, os degraus são nivelados, não estimulando assim um sentimento de falha ao não atingir um nível mais alto de participação em todas as ações realizadas com crianças.

Apesar das diversas concepções, Thomas (2007) não defende nenhuma teoria final sobre a Participação Infantil, apenas propõe alguns pontos de reflexão a serem levados em consideração pela área (p. 215, tradução nossa).
a) englobar os espaços em que a participação de crianças pode ou não existir; b) estar localizado em um amplo contexto de relações inter- geracionais;
c) compreender a distinção entre 'participação' enquanto atividades que crianças se engajam junto com adultos, e atividades autônomas de crianças e jovens;
d) acomodar as novas formas de práticas participatórias com crianças e jovens que têm sido desenvolvidas (particularmente em países do mundo maioritário);
e) responder às demandas de crianças e jovens em ter os mesmos direitos políticos que os adultos.

Em outro levantamento de concepções acerca de práticas participativas com crianças foram encontrados modelos e embasamentos teóricos provenientes de diversas áreas do conhecimento, como psicologia, geografia, sociologia, educação ambiental, planejamento urbano e desenvolvimento comunitário (MALONE; HARTUNG, 2010). As autoras também defendem que os modelos em forma de escada ou escala podem carregar concepções equivocadas das práticas participatórias e usam como base de análise sete reinos de ações propostos por Francis e Lorenzo (2002). Esses últimos autores, após análise de três décadas de 
práticas descritas nas áreas de Arquitetura, Políticas Públicas, Educação e Geografia, concluem que as práticas participatórias podem ter o caráter:

1. Romântico: crianças conseguem definir e fazer acontecer seu próprio futuro, frequentemente sem intervenção de adultos;

2. De advocacia: projetos planejados predominantemente por crianças, com defesa (advocacia) de algumas necessidades feitas por adultos;

3. De necessidades: ações voltadas principalmente ao urbanismo, no qual as necessidades espaciais das crianças são consultadas e incorporadas ao design;

4. De aprendizagem: práticas com foco em mudanças de percepções e habilidades, sem necessariamente refletir em mudanças de estruturas de poder ou espaços físicos;

5. De direitos: alinhado com documentos internacionais (como a Convenção Internacional sobre o Direito das Crianças), com foco maior nos direitos das crianças;

6. Institucional: fóruns, conselhos e outros formatos estabelecidos no mundo adulto e adaptados para a Participação Infantil;

7. De pro atividade: ações que buscam um balanço entre o empoderamento infantil por meio da participação e a realização de mudanças substanciais.

Pautando-se nessa proposta, é possível compreender que as ações de Divulgação Científica participatórias poderiam transpassar por diversos reinos pela variedade de conteúdos que podem ser trabalhados, especialmente no que diz respeito a temas sociocientíficos e controversos. No caso da relação entre museus e centros de ciência com o público infantil, Iszlaji (2012), em sua dissertação de mestrado, fez um levantamento quanto a suas exposições, ações educativas e objetivos. A pesquisadora verificou que, dos museus analisados, 78\% afirmaram contemplar o público infantil por meio de sua exposição e $89 \%$ por meio de suas ações educativas e dos objetivos. Os museus analisados responderam ainda que buscam:

(...) despertar a curiosidade, a experimentação e o interesse pela ciência e seus fenômenos de forma lúdica, provocativa e prazerosa, com percentual de 43\%; e contribuir com a Divulgação Científica e alfabetização científica para o público infantil, com 17\%. (ISZLAJI, 2012, p. 93)

Embora não se possa considerar que as exposições e ações educativas tenham caráter participatório, pode-se observar um objetivo central alinhado com um caráter de aprendizagem, segundo os reinos propostos por Francis e Lorenzo (2002). 
Em um estudo de caso, Leporo (2015) pesquisou as interações de crianças com os aparatos em visitas espontâneas à exposição "O Mundo Gigante dos Micróbios" do Museu de Microbiologia do Instituto Butantan localizado na cidade de São Paulo, SP. Dos 120.000 visitantes anuais do Museu de Microbiologia, cerca de 8.000 são crianças de 4 a 6 anos (LEPORO, 2015). Apesar disso, sua exposição original era voltada somente a alunos de ensino médio, surgindo uma demanda por parte das famílias visitantes por um espaço que acolhesse as crianças pequenas. Essa questão deu início à concepção da exposição "O Mundo Gigante dos Micróbios", sendo convocado um grupo técnico para sua elaboração. O grupo realizou coletas de dados para conhecer melhor as compreensões que o público-alvo, crianças entre 4 e 6 anos, possuem em relação ao universo microbiológico. Com esses resultados, a exposição foi criada baseada em eixos temáticos com objetivos distintos: Escala, Diversidade, Função Biológica, Relação com os seres humanos e Alimentação. De maneira geral, os objetivos da exposição são: (1) apresentar conteúdos e conceitos da microbiologia; (2) romper a visão de microrganismos como "seres do mal" e (3) apresentar como esses seres microscópicos estão relacionados com os seres humanos. Assim, além de um "caráter de aprendizagem", a presença de um grupo de famílias durante a pesquisa, apesar de ter níveis consultivos de participação por parte das crianças, pode se alinhar com um caráter focado nas necessidades das crianças semelhante a pesquisas participativas voltadas ao design de espaços infantis.

Nesse sentido, várias são as contribuições dos diversos modelos e modos de Participação Infantil para as práticas e pesquisas em DC com crianças. Se por um lado, a participação das crianças nos revelam importantes aspectos da sua forma de significar o mundo, por outro a comunidade científica e seus comunicadores possuem regras e normas específicas de seu universo, majoritariamente adulto. Quais seriam os modos de participação das crianças em práticas de DC possíveis de serem promovidos?

\subsection{Participação infantil na DC: culturas da infância e imaginação}

Como discutido nos capítulos anteriores, a promoção de práticas participatórias de Divulgação Científica com crianças pode esbarrar em questões de diversas naturezas. Se por um lado, o nível mais alto de participação leiga é praticamente inviável de ser alcançado na

Divulgação Científica, por outro existem diversos exemplos de crianças propondo e coordenando ações em diversos contextos (Cf PERCY-SMITH; THOMAS, 2010). Para 
Sarmento (2004), também não é factível pensar nas culturas da infância de maneira descolada do mundo dos adultos. Segundo o autor,

(...) não obstante, seria desajustado compreender as culturas da infância desligadas das interacções com o mundo dos adultos. Esta interacção não apenas é contínua e produtora de formas de controlo dos adultos sobre as crianças, como tem como meio da sua expressão a utilização pelos adultos de meios de configuração dos mundos específicos da criança, a partir dos elementos característicos das culturas infantis. Isso é particularmente visível no domínio dos jogos e brinquedos (SARMENTO, 2004, p. 10, grifo do autor).

Assim, aproximações são necessárias entre as culturas da infância e da Divulgação Científica. Se a primeira é essencial para a compartilhar as formas "especificamente infantis de inteligibilidade, representação e simbolização do mundo" (SARMENTO, 2004 p. 12) entre as crianças, a segunda é uma importante ferramenta de compartilhamento de significados, sentido e identidades da comunidade científica na sociedade (DAVIES; HORST, 2016). Para o fortalecimento desse diálogo, se faz necessária a compreensão dos traços distintivos das culturas da infância.

Sarmento (2004) propõe que a gramática das culturas da infância se exprime em três dimensões: (1) semântica; (2) sintaxe e (3) morfologia. A primeira diz respeito à construção de significados autônomos, aos processos de referência e significação próprios das crianças. A segunda consiste na "articulação dos elementos constitutivos da representação, que não se subordinam aos princípios da lógica formal, mas sustentam a possibilidade de contradição" (p. 13). E por fim, a terceira se refere às formas dos elementos das culturas infantis: jogos, brinquedos, rituais, gestos e palavras.

Essa compreensão das culturas da infância nos revela suas particularidades e formas de simbolização do mundo. A escolha por se trabalhar com estórias na DC se mostra promissora por, de certa forma, permear os três elementos dessa gramática. Apesar das estórias serem presentes também no mundo dos adultos, é nas culturas da infância que possuem maior presença, sendo uma forma para seus elementos (morfologia). Segundo Rubira (2006), as estórias são ações, pensamentos e sentimentos condensados em forma de metáforas, constituindo-se como um importante elemento de mediação entre o real e o imaginário. Nesse sentido, se aproxima também do que Sarmento (2004) denominou da sintaxe das culturas da infância, ou seja, a relação não literal dos elementos das culturas infantis e a contradição da própria identidade das crianças. As crianças são capazes de imaginar e se projetarem no que brincam, veem e ouvem: 
O "então eu era o herói” da criança - cantado por Chico Buarque da Holanda - exprime bem esta ideia de um ser que se outra no que vê e projecta e, por isso, articula na ordem do discurso o real e o imaginário, o ser e o não ser, o estar e o devir, homologizados na sua dupla face (SARMENTO, 2004, p. 13, grifo do autor).

Por fim, no que diz respeito à semântica, cabe uma reflexão sobre a participação das crianças no processo de produção da DC, pois a significação do mundo por parte das crianças se dá diferentemente das formas adultas (SARMENTO, 2004). Se para o mundo adulto o fazde-conta é um momento separado do "fazer coisas sérias", a ludicidade é fundamental para as culturas das crianças "sendo o brincar muito do que as crianças fazem de mais sério" (SARMENTO, 2004, p. 10). Essa dicotomia entre real e imaginário é demasiadamente frágil, estando esses mundos efetivamente associados nas culturas da infância. Para o autor, essa imbricação apresenta-se como um elemento central da capacidade das crianças de resistência e superação de situações dolorosas (SARMENTO, 2003). Um exemplo desse fenômeno característico da cultura da infância diz respeito ao papel do tempo durante uma brincadeira. $\mathrm{O}$ “era uma vez" não remete a uma ação passada, mas sim a uma iniciação, indicando uma nãolinearidade entre o fazer e o imaginar. A repetição de ações também é um fator marcante uma vez que as brincadeiras são reiteradas continuamente em um tempo sem medidas, abertas às transformações e novas experimentações de um recomeço. Ainda dentro da analogia com a gramática $^{19}$, Sarmento aponta que essa reiteração e não-linearidade do tempo pode se exprimir tanto no plano sincrônico, “com a contínua recriação das mesmas situações e rotinas", quanto no plano diacrônico, por meio da "transmissão de brincadeiras, jogos e rituais das crianças mais velhas para as crianças mais novas, de modo continuado e incessante, permitindo que seja toda a infância que se reinventa e recria, começando tudo de novo" (SARMENTO, 2004 p. 18). Apesar da reinvenção e recriação contínua, os processos imaginativos possuem limites criativos com base no contexto social e cultural de quem está criando e imaginando.

Segundo a psicologia histórico-cultural a relação entre real e imaginário se dá em diversos níveis, sendo que em uma atividade criativa, elementos do mundo real são reorganizados e projetados na imaginação (VIGOTSKI, 2014). Dessa forma, a imaginação é uma faculdade mental humana capaz de criar ideias, personagens, narrativas e conceitos novos partindo do que é experienciado empiricamente. Durante uma contação de estórias ou uma brincadeira de faz de conta, as crianças terão como base o que já experienciaram durante a vida

\footnotetext{
${ }^{19}$ Dentro da semântica, os termos (1) sincrônico e (2) diacrônico representam, respectivamente, os processos de significação em um (1) momento dado e (2) ao longo da história.
} 
para compor os elementos de suas narrativas e brincadeiras. Para Vigotski, a imaginação é o fundamento de toda atividade criadora (ou criatividade) e se apresenta igualmente em diversos aspectos da vida cultural, possibilitando a criação artística, científica e tecnológica (VIGOTSKI, 2014), ou seja, elementos essenciais para a produção de materiais de DC. Toda produção cultural, seja ela científica, artística ou de qualquer outra natureza, passa por esse processo criativo de constante relação entre real e imaginário, no qual um influencia o outro e possibilita o surgimento de novos produtos culturais no âmbito da realidade. Dessa forma, a criação de estórias e sua produção para a rádio e de forma audiovisual são exemplos desse movimento entre real e imaginário, resultando em produtos no mundo concreto.

Com os referenciais de DC participatória e Participação Infantil, é possível retomar os objetivos dessa pesquisa por meio de duas questões norteadoras:

- Quais modos de participação são possíveis de serem promovidos em práticas participatórias de DC para e com crianças?

- Quais os desafios e possibilidades de ações de coprodução de mídias de DC para e com crianças? 


\section{Abordagem teórico-metodológica}

Para o entendimento dos modos de Participação Infantil no processo de produção de mídias para a Divulgação Científica que valorizam os saberes da infância, a presente pesquisa partiu da premissa de que seria necessário disponibilizar às crianças um espaço criativo em que pudessem atuar como produtoras do discurso da Divulgação Científica. Essa premissa foi estabelecida frente à escassez de práticas de DC em que as crianças assumem tal papel.

\subsection{Instituições parceiras}

As ações elaboradas para fins de pesquisa ocorreram no período de março a maio de 2017, nos municípios de Passos Maia e de Ponte Serrada, no oeste do estado de Santa Catarina. A escolha do local foi feita em parceria com o Instituto Espaço Silvestre e com as Secretarias de Educação desses municípios. Inicialmente, as ações seriam realizadas em um espaço da Secretaria Municipal de Passos Maia, a chamada Sala Verde, com convite para crianças interessadas em atuar no projeto de reintrodução do papagaio-de-peito-roxo. Entretanto, no período de disponibilidade do pesquisador a sala não estava finalizada. Além disso, as Secretarias de Educação de ambos os municípios sugeriram que as atividades fossem realizadas em escolas por serem locais que reúnem um grande número de crianças, o que facilitaria questões logísticas, especialmente nas zonas rurais dos municípios.

\subsubsection{Instituto Espaço Silvestre}

O Instituto Espaço Silvestre (IES) é uma organização não-governamental (ONG), sem fins lucrativos, fundada em 1999 com o nome de Instituto Carijós. Seu principal objetivo é contribuir para a conservação da biodiversidade por meio da ciência, educação e desenvolvimento socioeconômico. Desde agosto de 2010, se dedica ao projeto "Reintrodução do papagaio-de-peito-roxo (Amazona vinacea) no Parque Nacional das Araucárias, SC", tendo realizado, até o primeiro semestre de 2019, seis grupos de soltura, somando 186 indivíduos reintroduzidos ${ }^{20}$. Apesar da pequena população de papagaios-de-peito-roxo reintroduzidos na região, a forte presença do Instituto Espaço Silvestre auxilia em uma maior percepção à presença da ave no local. Por meio de ações de ciência-cidadã, atende a chamados de moradores

\footnotetext{
${ }^{20}$ Para mais informações, cf. <https://www.espacosilvestre.org.br/projetos $>$, acesso em 31 jul 2019.
} 
que avistam o papagaio-de-peito-roxo (Figura 3), implantando pontos de observação próximos aos locais relatados. Além disso, com a parceria das prefeituras dos municípios, os ônibus escolares e carros oficiais possuem em seus vidros traseiros artes e fotografias do papagaio-depeito-roxo (Figura 4). Mais recentemente, com apoio também das prefeituras e do Parque Nacional das Araucárias, placas foram colocadas nos arredores do parque com informações sobre o papagaio-de-peito-roxo, a araucária, o pinhão, entre outras espécies (Figura 5). Essa relação com o Parque Nacional das Araucárias também é refletida em seu logotipo (Figura 6), composto por três elementos da região decididos por meio de votação popular: o papagaio-depeito-roxo, a araucária e os rios.

Figura 3. Exemplo de material do Instituto Espaço Silvestre com chamado para ciênciacidadã.

\section{(7)}

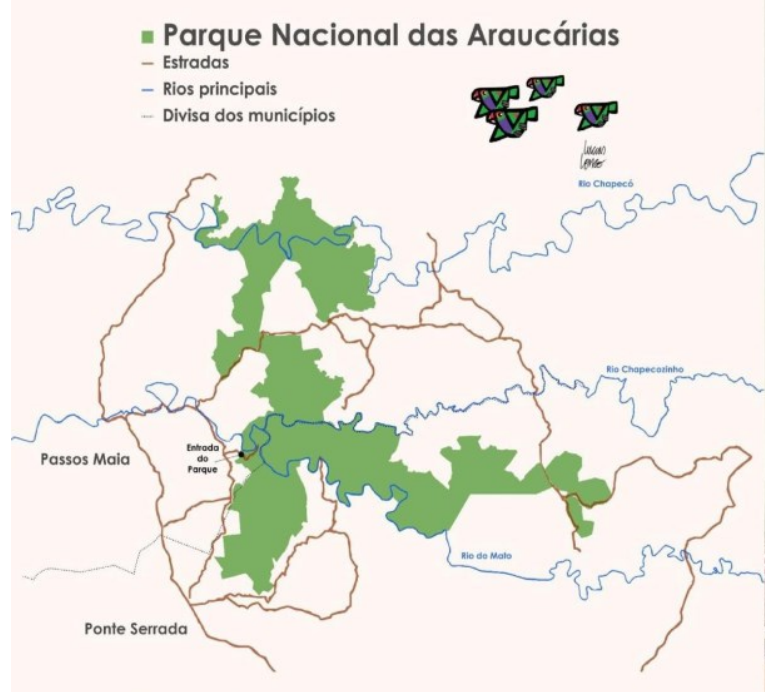

Viu um papagaio-de-peito-roxo?

Entre em contato:

(49) 99805-3989 0

www.espacosilvestre.org.br

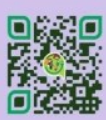

Sabia que você pode ser um cidadão-cientista?

Ajude-nos a monitorar os papagaios-de-peito-roxo em vida livre!

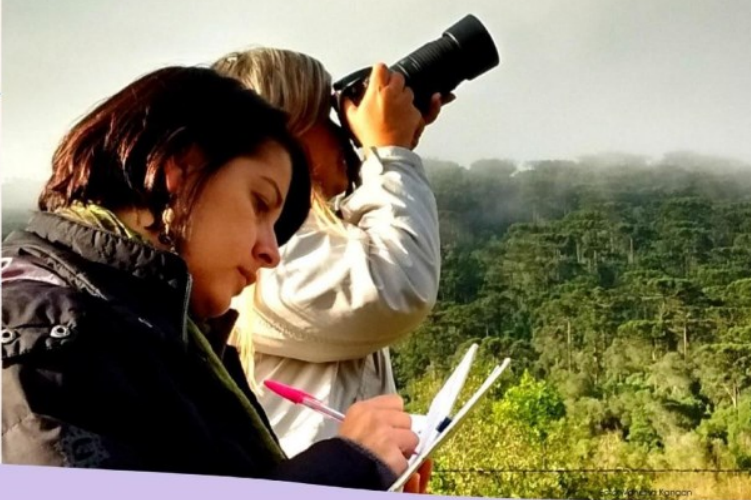

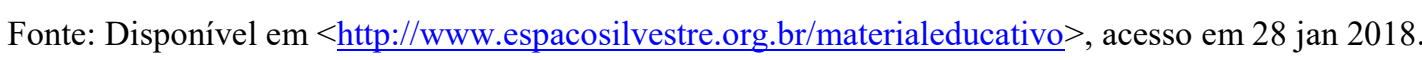


Figura 4. Arte com o papagaio-de-peito-roxo em vidro traseiro do carro oficial da Secretaria Municipal da Educação de Passos Maia.

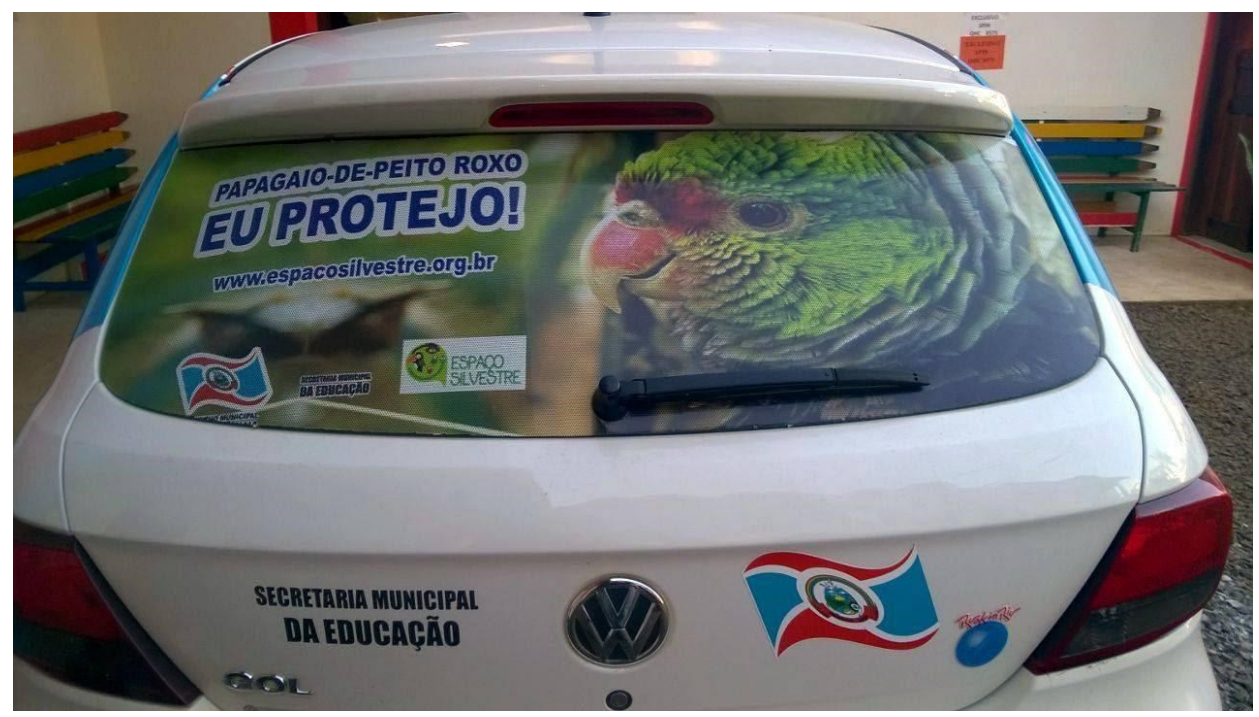

Fonte: Disponível em <https://www.facebook.com/EspacoSilvestre>, acesso em 28 jan 2018.

Figura 5. Exemplo de placa colocada nos arredores do Parque Nacional das Araucárias, SC.
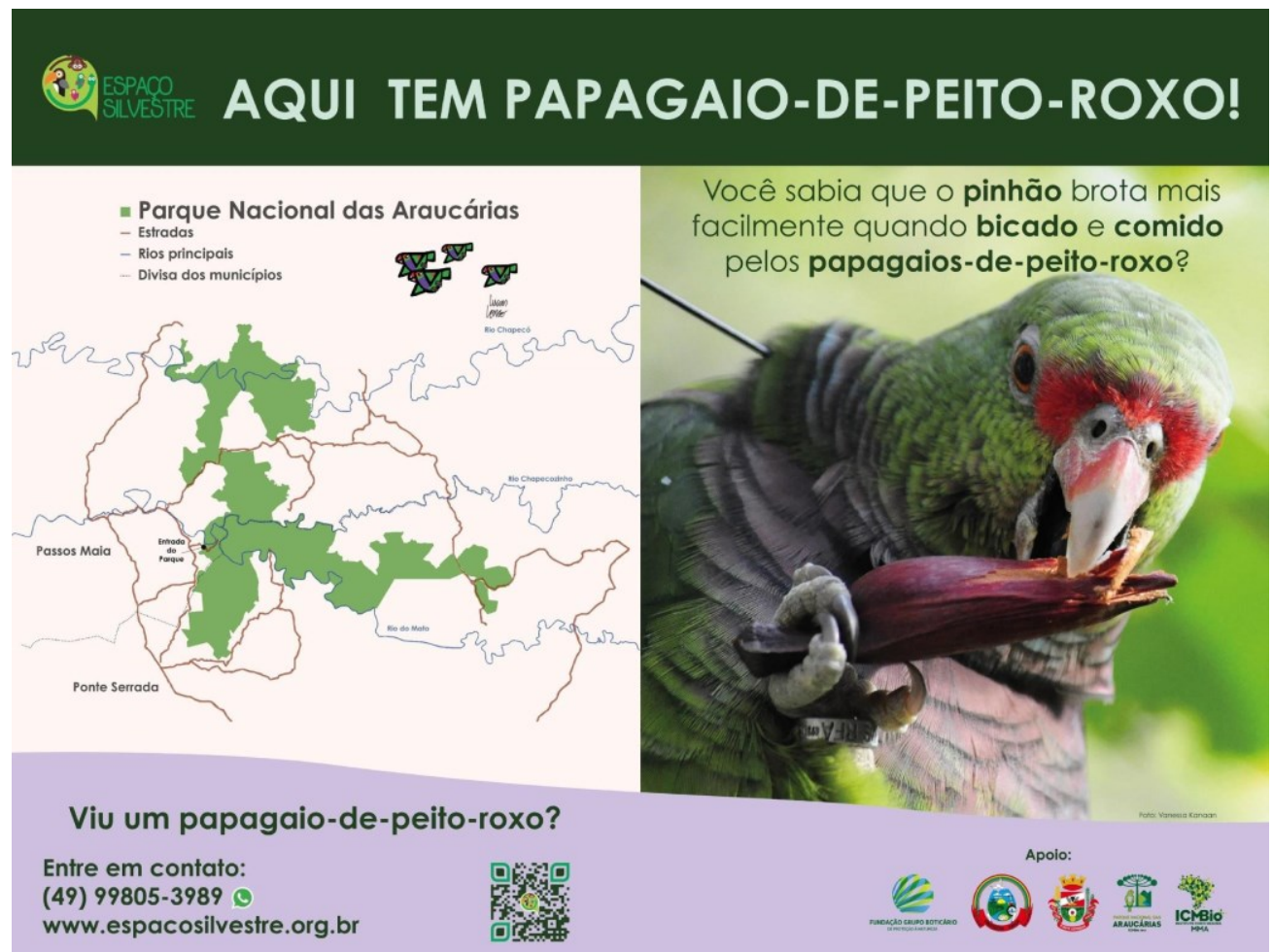

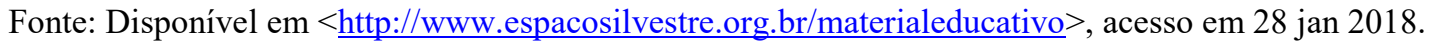


Figura 6. Logomarca do Parque Nacional das Araucárias, SC.
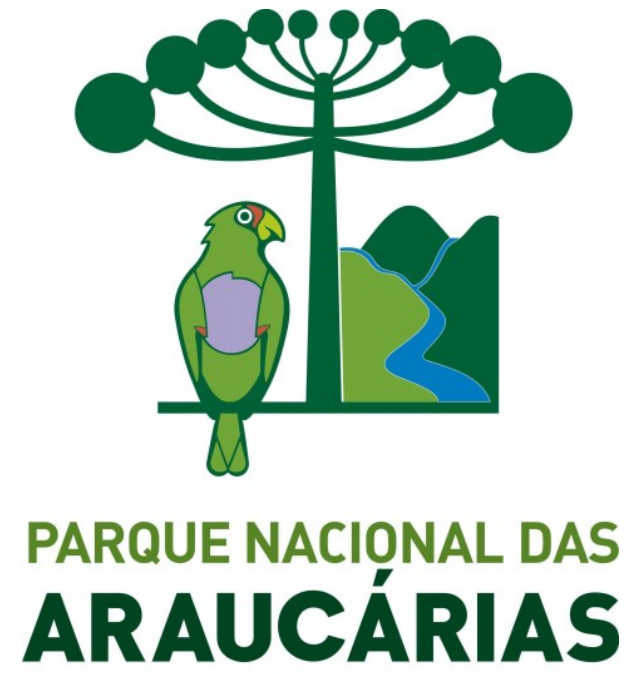

ICMBio-MMA

Fonte: Disponível em $<$ http://www.icmbio.gov.br/portal/unidadesdeconservacao/biomas-brasileiros/mataatlantica/unidades-de-conservacao-mata-atlantica/2199-parna-das-araucarias $>$, acesso em 28 jan 2018.

Além das ações de treinamento e reabilitação dos papagaios-de-peito-roxo, a equipe realiza monitoramento da população do Parque Nacional das Araucárias e atividades de educação ambiental. Além disso, o Instituto auxiliou na criação e manutenção de um programa de geração de trabalho e renda com as mulheres da região. Dentre as atividades de educação ambiental estão: palestras, mostras fotográficas, conversas com os moradores locais, produção de materiais didáticos, formação continuada de professoras e parcerias com escolas e Secretarias de Educação dos municípios de Passos Maia e Ponte Serrada.

Ao longo da pesquisa participaram mais de 200 crianças e foi enviado um Termo de Consentimento Livre e Esclarecido (APÊNDICES 11-12) para cada uma das famílias responsáveis, com auxílio das diretorias das escolas. Nesta pesquisa, o contato com os grupos de crianças da região se deu por meio da parceria com três escolas em diferentes contextos, uma em Ponte Serrada e duas em Passos Maia, com apoio das respectivas Secretarias de Educação de ambos os municípios.

\subsubsection{Escola de Tempo Integral Tancredo de Almeida Neves}

Localizada no Centro de Tradições Gaúchas (CTG) de Ponte Serrada, a Escola de Tempo Integral Tancredo de Almeida Neves recebe crianças do primeiro ao quinto ano do Ensino Fundamental. Localizada em uma região periférica do município, é ligada ao centro do 
município por um trecho de aproximadamente $4 \mathrm{~km}$ de uma rodovia federal. Com tais distâncias geográficas, o bairro do CTG (como é conhecido) possui uma identidade própria. As crianças se reconhecem enquanto grupo (social e geográfico) se referindo ao centro de Ponte Serrada como "cidade".

A escola atende as crianças de Ensino Fundamental I desse bairro, com cerca de 100 crianças. Com a posse da nova gestão da prefeitura, em 2017, teve sua equipe profissional trocada por decisão da Secretaria de Educação. A partir deste período, a escola também começou a atender seus alunos em tempo integral, oferecendo atividades de contra turno de caratê, artes, educação física e leitura. As ações relacionadas a esta pesquisa foram realizadas com as turmas de primeiro a quarto ano do Ensino Fundamental I, com crianças de 6 a 10 anos.

\subsubsection{Escola Municipal Rural Maria Francisca Maciel}

Localizada em uma vila de trabalhadores de uma serraria, é uma escola pequena da zona rural de Passos Maia, com apenas duas pequenas turmas multisseriadas (uma com crianças da Educação Infantil e a outra com crianças do Ensino Fundamental I), atendidas pela mesma professora em turnos opostos. Possui também uma educadora do Serviço de Convivência e Fortalecimento de Vínculos, que atende as crianças no contraturno com atividades artísticas. Conta ainda com duas moradoras que frequentam uma escola de Ensino Fundamental II no centro do município. Seu corpo funcional inclui uma merendeira que, além da alimentação, cuida da limpeza das salas e área externa.

As relações entre as crianças, funcionárias e professora são bem estreitas, sendo a maioria deles vizinhos e/ou parentes. Seu principal produto comercial é o cultivo e extração de pinus e eucalipto, possuindo assim, conflitos com o Instituto Chico Mendes de Conservação da Biodiversidade (ICMBIO), autarquia vinculada ao Ministério do Meio Ambiente, responsável pela gestão do Parque Nacional das Araucárias. A principal tensão no local é pela delimitação da área da Unidade de Conservação criada em 2005, mas ainda dependente das desapropriações e indenizações planejadas.

A turma multisseriada participante variou de 6 a 7 crianças de 5 a 10 anos de idade ao longo das ações. No contra turno, duas crianças de 12 anos se juntavam às demais e, com exceção de uma criança da turma, frequentavam o Serviço de Convivência e Fortalecimento de Vínculos, participando das ações de construção e gravação das estórias no período vespertino. 


\subsubsection{Escola de Educação Infantil e Ensino Fundamental Nossa Senhora Aparecida}

Afastada cerca de vinte quilômetros do centro do município de Passos Maia, a Escola Zumbi, como é mais conhecida, faz parte da área de um assentamento do Movimento dos Trabalhadores Rurais sem Terra (MST). Zumbi dos Palmares possui 1745 hectares onde moram 95 famílias e é o maior assentamento de Passos Maia ${ }^{21}$.

A escola atende cerca de 90 crianças de Educação Infantil e Ensino Fundamental I e a maioria de suas funcionárias não mora na região. Por ser bastante afastada do centro, possui algumas tensões no nível político devido ao poder da Prefeitura (e Secretaria de Educação) do município de transferir e rearranjar equipes profissionais para cada escola.

Para a realização das ações, as turmas de primeiro a terceiro anos do Ensino Fundamental se reuniam em um salão no período da manhã, contando com cerca de 45 crianças e 3 professoras. No período da tarde, as crianças das turmas de quarto e quinto ano do Ensino Fundamental e as crianças mais velhas da Educação Infantil se juntavam, formando uma turma de cerca de 45 crianças e 4 professoras para a realização das atividades.

\subsection{Descrição das ações}

Após o contato com as Secretarias de Educação de Passos Maia e Ponte Serrada, foram marcadas reuniões com as diretorias das três escolas. Durante essa reunião, ficou acordado o início dos trabalhos, bem como os horários e frequência dos encontros com as crianças.

Neste subitem serão descritas as ações exercidas junto às crianças das três escolas para a produção das mídias analisadas nesta dissertação. Para isso, o texto a seguir será dividido pelas ações de cada um dos encontros, seguindo a mesma estrutura com as sete turmas.

\section{Prólogo - Encontro inicial}

No primeiro dia houve o contato inicial com as crianças das três escolas e foram realizadas as primeiras conversas com o pesquisador. Durante essa troca de ideias, foram compartilhadas as visões das crianças em relação ao projeto de Reintrodução do papagaio-depeito-roxo no Parque Nacional das Araucárias/SC, conhecido popularmente na região como "Projeto do papagaio-de-peito-roxo". Por ter sido o primeiro contato do pesquisador com as

\footnotetext{
${ }^{21}$ Disponível em < $\underline{\text { http://www.incra.gov.br/> }}$, acesso em: 27 jan 2018.
} 
crianças, além do tema central do projeto houve conversas sobre os mais diversos temas como: gostos em geral, futebol, curiosidades de São Paulo, tradições locais, entre outros.

Após a rodada inicial de apresentação, houve a introdução do projeto a ser realizado com participação das crianças. Por ter sido determinado a priori entre o pesquisador e o IES que o trabalho de DC se daria por meio de narrativas, foi introduzida essa temática com a leitura de algumas lendas do livro "Lendas e Contos Brasileiros com Animais"22 e compartilhamento de estórias de tradição oral com animais, contadas pelas crianças. Foi acordado que o trabalho semanal de produção de narrativas a serem transmitidas na rádio local para a divulgação do projeto de reintrodução. Para trabalhar os conhecimentos sobre o papagaio-de-peito-roxo de maneira empírica, foi combinado também que, na semana seguinte, um amigo papagaio iria participar do encontro. Por ter sido o primeiro contato com os sujeitos, as ações não foram registradas em meio audiovisual por dois motivos: (1) interesse em negociar de maneira prévia com as crianças a forma de gravação que ocorreria durante as semanas seguintes e (2) ausência do termo livre-esclarecido de uso de áudio e imagem assinado pelos pais ou responsáveis, providenciado a partir do segundo encontro.

Ficou acordado que uma câmera digital e um gravador de voz iriam registrar todos os encontros seguintes, sendo esse material manipulado pelo pesquisador. Em alguns momentos, as crianças puderam manipular câmeras de mão do Instituto Espaço Silvestre para registros nos pequenos grupos, estimulando que as negociações para a troca entre crianças ocorressem sempre que possível sem mediação de adultos. Nos momentos em que houve condução de adultos, o pesquisador ficou responsável por exercê-la com ajuda dos professores em questões operacionais. Apenas um episódio foi conduzido por uma professora, sem a presença do pesquisador, analisada nos capítulos seguintes.

\section{Episódio 1 - Criando personagens}

Com auxílio de um papagaio-de-peito-roxo taxidermizado, as crianças foram convidadas a criar as personagens que fariam parte da(s) estória(s) da turma ${ }^{23}$. Algumas das condições pré-estabelecidas era de ter, dentre elas, pelo menos um papagaio-de-peito-roxo e que a fauna brasileira (em especial a local) seria valorizada durante a criação da narrativa. Ao

\footnotetext{
${ }^{22}$ Cf. SATO et al., 2016 in SILVA; SILVA, 2016, p. 297 (disponível em:

$<$ http://www2.ib.usp.br/index.php?option=com docman\&task=doc download\&gid=70\&Itemid=98 $>$, acesso em 09 jan 2018).

${ }^{23}$ Por haver turmas muito maiores do que outras, optou-se por criar mais de uma estória em alguns grupos para garantir maior possibilidade de participação de todas as crianças.
} 
longo das conversas, características físicas e comportamentais dos animais (incluindo o papagaio-de-peito-roxo) foram discutidas, auxiliando na etapa seguinte de atribuição de características às personagens. Para sistematizar as escolhas e auxiliar nas decisões coletivas das turmas o pesquisador organizou turnos de votação para a escolha dos elementos que fariam parte da estória da turma. Assim, o nome de cada personagem era escrito na lousa the atribuindo características a serem decididas coletivamente com as crianças, com a organização de turnos de votação caso não houvesse consenso na decisão. Após as negociações, a turma foi convidada a ilustrar essas personagens individualmente e a imaginá-los interagindo na estória. Os desenhos foram entregues ao pesquisador e auxiliaram nas ações das semanas seguintes.

\section{Episódio 2 - Enredo, cinema e narração}

Com o convite para brincar de cinema, as crianças foram desafiadas a projetar, com o uso de lupas de mão, as janelas de sua sala de aula em um papel sulfite. Posteriormente, foram apresentadas aos projetores precários ${ }^{24}$, estrutura feita com uma caixa de papelão, lentes e fonte de luz que possibilita a projeção de transparências em anteparos a um baixo custo. Após a construção e manipulação do aparato, as crianças foram desafiadas a produzir pelo menos uma parte da estória e apresentá-la ao fim do encontro utilizando esse recurso.

A turma foi dividida em equipes e cada equipe ficou responsável pelas seguintes funções:

1. Roteiristas: encarregados de criar um enredo curto, pensando na estrutura da estória e desafios das personagens;

2. Ilustradores: responsáveis por desenhar as personagens em transparências nas situações presentes no enredo;

3. Narradores: encarregados da narração da estória enquanto os projetores manipulam as transparências com as personagens;

4. Projetores: responsáveis por projetar na tela as imagens das transparências, além de representar as ações das personagens durante as estórias.

A escolha das crianças pelos grupos foi livre e a alternância entre as equipes variou dentro das turmas trabalhadas. Em grupos menores, as crianças eram convidadas a participar de todas as funções enquanto que nas turmas maiores, devido à limitação de tempo e espaço, a

\footnotetext{
${ }^{24}$ Instruções disponíveis em $<\underline{\text { http://docs. wixstatic.com/ugd/c74d60_eb9da60ad2ee44489b02d510bcccae37.pdf> }}$, acesso em 09 jan 2018.
} 
participação efetiva de todas as crianças em todas as funções foi dificultada. Para tentar superar esse desafio, foi proposto que a mudança entre grupos podia ser realizada pelas crianças se terminassem sua função anterior. Com isso, as estórias começaram a tomar forma, representadas de diversas maneiras nas semanas seguintes.

É importante ressaltar que o caráter particular de cada contexto influenciou a mediação das atividades, principalmente na criação de roteiros. Pelas diversas limitações, os enredos das estórias foram construídos em três possíveis contextos: (1) com mediação do pesquisador; (2) com mediação de professores e (3) sem mediação de adultos, com crianças criando autonomamente. Durante a mediação do pesquisador, decisões do enredo eram tomadas de maneira coletiva, buscando um consenso e propondo votações somente quando necessário. Como a mediação de professor não era esperada, não foi uma ação negociada previamente com o pesquisador, sendo a atividade conduzida a critério do educador. Nas atividades com criação autônoma das crianças é notável a presença de uma liderança que criava enquanto a estória era escrita. As diferenças, influências e limitações de cada contexto serão melhor exploradas nos resultados.

\section{Episódio 3 - Finalização da estória}

$\mathrm{Na}$ semana seguinte as estórias foram finalizadas com ajuda do pesquisador, com a escrita final realizada pelo adulto na maioria das vezes. Para a decisão da forma que seria escrita a estória, as ideias sugeridas foram negociadas e, em caso de concordância por parte das crianças, organizadas de forma que a estória fosse composta por frases que facilitassem a narração pelas crianças na semana seguinte.

\section{Episódio 4 - Gravação}

Com as estórias finalizadas, foi iniciado o processo de gravação. Devido à dificuldade de leitura pelas crianças, a contação foi realizada com auxílio de um adulto, realizando uma narração prévia do mediador para que a criança se baseasse no conteúdo. Gravou-se cada criança que demonstrou interesse em participar utilizando um gravador modelo Zoom H5. As edições não puderam ser realizadas conjuntamente com as crianças por falta de estrutura e tempo. Assim, foi feita externamente pelo pesquisador e entregue ao grupo na semana seguinte.

Episódio 5 - Recepção das estórias e finalização 
Finalizada a edição, as crianças foram convidadas a ouvir suas estórias editadas. As narrativas contaram com uma rápida introdução, contendo os nomes do Instituto Espaço Silvestre e da Nossa Rádio 100.7FM, bem como o título da estória. Além disso, continham uma trilha sonora de uso livre ${ }^{25}$. Com isso, foram ouvidas as opiniões sobre a edição, corrigindo os problemas técnicos apontados (volume baixo, cortes de fala repentinos, entre outros) para posterior envio para a rádio. Além de ouvir a(s) própria(s) estória(s), as crianças se interessaram em conhecer as narrativas criadas pelos outros grupos, sendo um momento de compartilhamento entre as diferentes realidades.

\section{Episódio 6 - Gravação audiovisual}

Além das gravações das radionovelas ${ }^{26}$, dois grupos interpretaram suas estórias pela mídia audiovisual ${ }^{27}$, escolhendo como iriam reproduzir as personagens e ambientes. As filmagens foram realizadas pelo pesquisador com ajuda de crianças interessadas no processo de captação. Semelhante à edição das radionovelas, o vídeo foi editado pelo pesquisador e apresentado às crianças em agosto de 2017, quando houve a estreia do curta metragem "Conversa Conserva" nos municípios de Ponte Serrada e Passos Maia.

\subsection{Produção dos dados}

A produção e construção dos dados dessa pesquisa contaram com ferramentas variadas, possibilitando a ocorrência de diferentes fontes de dados: (1) registro audiovisual das ações; (2) observações de campo e; (3) produção de estórias. Tais fontes serão descritas a seguir, juntamente com as motivações para cada escolha.

\footnotetext{
${ }^{25}$ As músicas estão sob licença Creative Commons CC BY-NC 4.0, com necessária atribuição de créditos ao artista britânico Scott Holmes. Como as estórias foram transmitidas via rádio, foi solicitada permissão ao autor para veiculação sem atribuição devido à falta de recursos visuais. O pedido foi atendido por e-mail no dia 17 de abril de 2017, possibilitando o uso das músicas com atribuição somente quando possível de ser feita.

${ }^{26}$ Inicialmente, o IES e o pesquisador idealizaram as estórias em uma estrutura de radionovela, ou seja, uma narrativa contínua contada em formato de áudio em pequenos episódios periódicos. Entretanto, como as turmas trabalharam simultaneamente na produção e criação de personagens, optou-se por serem narrativas curtas e independentes. Apesar disso, o nome "radionovelas" permaneceu como referência ao projeto em parceria com a rádio e é utilizado pelo IES para se referir a essas ações.

27 As estórias contadas visualmente podem ser assistidas no curtametragem "Conversa Conserva" (2017), disponível em < $\underline{\text { https://www.youtube.com/watch? } v=O s D f d o h n L S c}>$, acesso em 16 ago 2019.
} 


\subsubsection{Registro audiovisual das ações}

Para a pesquisa foram coletados imagem e som a partir do segundo encontro com as crianças. Para isso, uma câmera Canon SL-1 com lente de ângulo aberto (18-55mm) e um gravador de som Zoom H5 eram posicionados em algum canto da sala nas atividades com o grupo todo, registrando a maior quantidade de crianças possível. Nas atividades em grupos menores, câmeras de mão eram distribuídas aos grupos para que as crianças filmassem as atividades e a câmera principal era manipulada pelo pesquisador de maneira rotativa entre os grupos. Com isso, foi possível de se observar processos de produção das ações, um aspecto não-observável somente pela análise dos produtos. A análise da transcrição das falas durante essas interações possibilita também identificar as negociações e significados em jogo, bem como auxiliar na compreensão das identidades envolvidas. A transcrição das falas foi sistematizada em forma de episódios, sendo que cada episódio se refere a cada uma das ações semanais. Dessa forma, cada um dos sete grupos de crianças teve até seis episódios que seguem a descrição das ações apresentada anteriormente e estão sistematizados na Tabela 1.

Tabela 1. Transcrição de episódios.

\begin{tabular}{|c|c|}
\hline Episódio & Ação \\
\hline 1 & Criando personagens \\
\hline 2 & Enredo, cinema e narração \\
\hline 3 & Finalização da estória \\
\hline 4 & Gravação \\
\hline 5 & Recepção das estórias e finalização \\
\hline 6 & Gravação audiovisual \\
\hline
\end{tabular}

Fonte: O autor (2019).

No caso das turmas que produziram mais de uma estória, os episódios foram nomeados seguidos de letras (e.g. Grupo 1 Episódio 1a). 


\subsubsection{Observações de campo}

Durante as ações, foram feitas observações e notas sobre os contextos das escolas e das interações com as crianças e professoras. Tais anotações foram do tipo "não-estruturadas" com critérios para registro não estabelecidos a priori. Dessa forma, foram observados aspectos das relações entre as escolas e seus sujeitos, das crianças entre si e entre os adultos.

\subsubsection{Produção das estórias}

A estrutura das estórias pode nos revelar sua complexidade, bem como características da ressignificação interpretativa das crianças (SARMENTO, 2003), apontando elementos presentes tanto nas estórias quanto em suas brincadeiras. A seguir será apresentado um breve contexto da produção das estórias e como se deu sua mediação.

As estórias 1 e 2 foram desenvolvidas pela mesma equipe (grupo 1), sendo "Tobi, Susu e a tempestade!" (Apêndice 1) escrita depois de "A floresta escondida" (Apêndice 2) e com a ajuda de duas crianças mais velhas não pertencentes ao grupo. As crianças que escreveram "A floresta escondida" tinham de 5 a 10 anos, produzindo todo o enredo com auxílio do pesquisador e tendo a participação das crianças mais velhas (com 12 e 13 anos) somente na narração final. Já na produção de "Tobi, Susu e a Tempestade" a ajuda do pesquisador foi reduzida, auxiliando apenas na etapa de sistematização das personagens no início na construção, não tendo influência direta no enredo. Além disso, em "Tobi, Susu e a Tempestade" as crianças foram responsáveis pela gravação da estória em forma audiovisual e toda a estética do vídeo foi proposta pelo grupo.

As estórias 3 e 4 foram escritas pela mesma turma (grupo 2), composta por crianças de 9 e 10 anos, mas em contextos bem diferentes. "Papagaios Chico e Chica" (Apêndice 3) foi criada inicialmente pelas crianças sem mediação de adultos, escrita em sua forma final com ajuda do pesquisador. Já "Os animais da mata" (Apêndice 4) foi criada com ajuda do pesquisador utilizando as estratégias descritas no subitem 6.2.

As estórias 5 e 6 foram produzidas pela mesma turma (grupo 3) de crianças de 6 a 8 anos, e foram facilitadas por adultos diferentes. Enquanto "O papagaio Dedé e o Dragão!" (Apêndice 6) teve sua condução feita totalmente pelo pesquisador, "O papagaio Rico e seus amigos" (Apêndice 5) foi conduzido por uma professora, com exceção da criação de seus 
personagens, que teve ajuda do pesquisador. Em "O Papagaio Dedé e o Dragão" houve a produção de um vídeo em que a montagem foi feita pelo pesquisador com técnica de stop motion usando os desenhos feitos pelas crianças.

Para finalizar, as estórias 7, 8, 9 e 10 foram escritas por turmas diferentes de crianças de 6, 7, 8 e 9 anos respectivamente, sendo cada equipe responsável por apenas uma estória. Em relação a mediação, houve pouca variação entre estas quatro estórias e foi realizada pelo pesquisador. Vale ressaltar que além desses quatro grupos, dois grupos da mesma escola não quiseram produzir uma estória, sendo que foram realizadas ações educativas alternativas e que não compuseram os dados dessa pesquisa. $\mathrm{O}$ único vídeo produzido por esses grupos foi " $\mathrm{O}$ Papagaio e os amigos dele", no qual a estória foi interpretada pelas crianças com o uso de fantoches da sala de leitura da escola. A Tabela 2 resume os grupos de crianças e adultos envolvidos no processo de produção de cada uma das 10 estórias. 
Tabela 2. Resumo dos contextos de produção das estórias.

\begin{tabular}{|c|c|c|c|c|}
\hline $\mathrm{E}$ & Título & Grupo & Crianças & Adultos \\
\hline E1 & A floresta escondida & \multirow{2}{*}{1} & $\begin{array}{l}6 \text { a } 7 \text { crianças de } \\
5 \text { a } 10 \text { anos de } \\
\text { idade. }\end{array}$ & $\begin{array}{l}\text { Pesquisador conduziu todas as ações } \\
\text { durante a produção. }\end{array}$ \\
\hline E2 & Tobi, Susu e a tempestade! & & $\begin{array}{l}7 \text { a } 8 \text { crianças de } \\
5 \text { a } 12 \text { anos de } \\
\text { idade. }\end{array}$ & $\begin{array}{c}\text { Pesquisador auxiliou no registro, em } \\
\text { lousa, da narrativa criada pelas } \\
\text { crianças. }\end{array}$ \\
\hline E3 & Papagaios Chico e Chica & \multirow{2}{*}{2} & \multirow{2}{*}{$\begin{array}{c}\text { Aprox. } 40 \\
\text { crianças de } 9 \text { e } \\
10 \text { anos de } \\
\text { idade. }\end{array}$} & $\begin{array}{c}\text { Estória criada por crianças com auxílio } \\
\text { do pesquisador na criação de } \\
\text { personagens, escrita final e gravação. }\end{array}$ \\
\hline E4 & Os animais da mata & & & $\begin{array}{l}\text { Pesquisador conduziu todas as ações } \\
\text { durante a produção. }\end{array}$ \\
\hline E5 & $\begin{array}{l}\text { O papagaio Rico e seus } \\
\text { amigos }\end{array}$ & \multirow{2}{*}{3} & \multirow{2}{*}{$\begin{array}{l}\text { Aprox. } 40 \\
\text { crianças de } 6 \text { a } 8 \\
\text { anos de idade. }\end{array}$} & $\begin{array}{l}\text { Pesquisador auxiliou na criação de } \\
\text { personagens, com a criação do enredo } \\
\text { conduzida por uma professora. }\end{array}$ \\
\hline E6 & $\begin{array}{l}\text { O papagaio Dedé e o } \\
\text { Dragão! }\end{array}$ & & & $\begin{array}{l}\text { Pesquisador conduziu todas as ações } \\
\text { durante a produção. }\end{array}$ \\
\hline E7 & $\begin{array}{l}\text { Os passarinhos e o Monstro } \\
\text { de Ferro! }\end{array}$ & 4 & $\begin{array}{c}\text { Aprox. } 15 \\
\text { crianças de } 6 \\
\text { anos de idade. }\end{array}$ & $\begin{array}{l}\text { Pesquisador conduziu todas as ações } \\
\text { durante a produção. }\end{array}$ \\
\hline E8 & $\begin{array}{l}\text { A guerra contra os } \\
\text { cortadores de árvores }\end{array}$ & 5 & $\begin{array}{c}\text { Aprox. } 10 \\
\text { crianças de } 7 \\
\text { anos de idade. }\end{array}$ & $\begin{array}{l}\text { Pesquisador conduziu todas as ações } \\
\text { durante a produção. }\end{array}$ \\
\hline E9 & $\begin{array}{c}\text { O papagaio-de-peito-roxo e } \\
\text { a Bruxa! }\end{array}$ & 6 & $\begin{array}{c}\text { Aprox. } 10 \\
\text { crianças de } 8 \\
\text { anos de idade. }\end{array}$ & $\begin{array}{l}\text { Pesquisador conduziu todas as ações } \\
\text { durante a produção. }\end{array}$ \\
\hline E10 & O papagaio e os amigos dele & 7 & $\begin{array}{l}\text { Aprox. } 15 \\
\text { crianças de } 9 \\
\text { anos de idade. }\end{array}$ & $\begin{array}{l}\text { Pesquisador conduziu todas as ações } \\
\text { durante a produção. }\end{array}$ \\
\hline
\end{tabular}

Fonte: o autor (2018).

As estórias foram produzidas com base no referencial do "Esquema de Estórias" (Story Schema), de Stein e Glenn (1975). Para as autoras, as estruturas das estórias seguem uma lógica hierárquica de resolução de desafios: possuem um cenário e, nele, episódios ocorrendo segundo a estrutura do esquema a seguir (Figura 2). Entretanto, os episódios não precisam seguir tal sequência nem possuir todos os elementos, sendo isso particularidade de cada estrutura narrativa. 
Figura 7. Estrutura de um Episódio Simples (STEIN; GLENN, 1975).

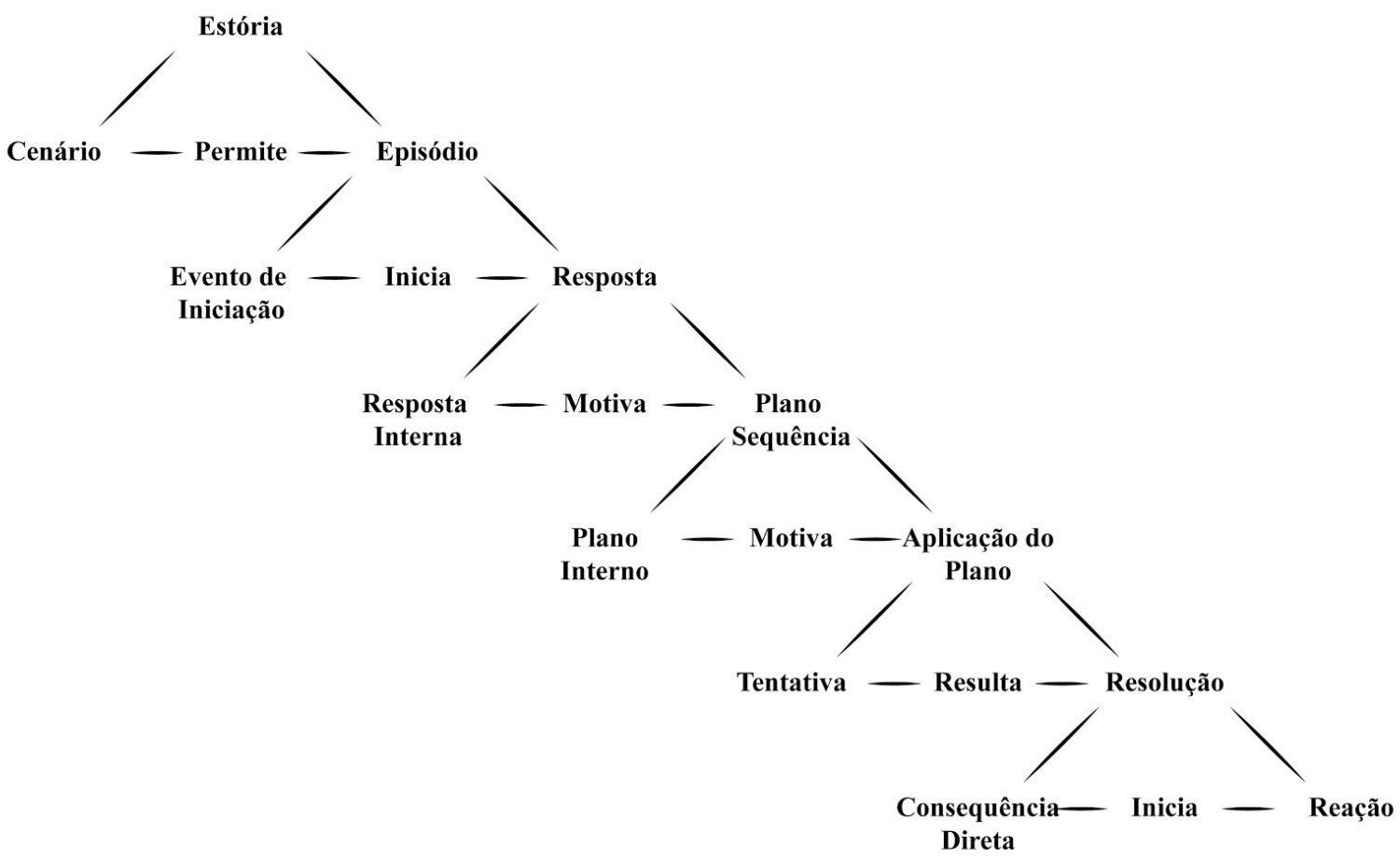

Fonte: Adaptado de Stein; Glenn, 1975 (tradução nossa).

Com auxílio dessa ferramenta, as atividades de elaboração dos enredos com as crianças foram planejadas de forma que as estórias criadas apresentassem pelo menos um episódio e suas ações subsequentes. Nesse caso, a condução das atividades, quando mediadas pelo pesquisador, buscavam percorrer o esquema completamente: tendo eventos de iniciação, respostas e planos das personagens, tentativas de resolução, consequências diretas, reação e, quando possível, eventos de iniciação de novos episódios. Assim, a ferramenta do esquema de estórias serviu tanto para estruturar as ações educativas do projeto "Reintrodução do papagaiode-peito-roxo (Amazona vinacea) no Parque Nacional das Araucárias, SC" quanto para compor o quadro analítico, discutido a seguir.

\subsection{Quadro analítico}

Os dados serão analisados de uma maneira integrada, considerando-se tanto a estruturação e conteúdo das estórias criadas (produto de DC), quanto o processo de produção desses produtos (processo de DC). Nos processos de produção das estórias foram analisados 
tanto os registros audiovisuais quanto o caderno de campo do pesquisador, compreendendo assim as diversas negociações e tensões da construção dos significados compartilhados por meio das narrativas. Com a transcrição das ações com as crianças e a análise textual discursiva, pretende-se localizar episódios em que houve diferentes modos de Participação Infantil na produção das estórias. Com isso, pretende-se fomentar a discussão acerca dos desafios e limites da participação nesse processo. A partir desse material, é esperada também uma compreensão dos processos imaginativos envolvidos na criação das estórias, refletindo sobre seu potencial em promover a participação das crianças e suas identidades em ações de DC. As normas e regras presentes na regulação das atividades serão localizadas por meio dos registros audiovisuais, notas de campo e na produção das estórias. Com a triangulação dessas fontes de dados pode-se resgatar quais os acordos, explícitos ou implícitos, que envolveram os diferentes modos de participação ao longo das ações.

Assim, foram gerados, a posteriori, quatro modos de participação das crianças nos processos investigados: (1) contextual; (2) simbólico; (3) técnico/estético e; (4) identitário.

Para a discussão da participação contextual foram analisados episódios em que os elementos contextuais das crianças refletiram em mudanças nos processos de cocriação ou em seus produtos. Dessa forma, foram considerados elementos presentes no contexto local como os seres vivos, as palavras e costumes ou integrantes das culturas da infância para esse modo de participação.

No que diz respeito a como as crianças participam da construção do que é simbólico nos produtos seus significados representados, observou-se as diversas estruturas das estórias seguindo o "Esquema de Estórias” proposto por Stein e Glenn (1975). Nesse modelo, as estórias são:

1. Formadas por um cenário em que ocorrem episódios;

2. Cada episódio possui um evento de iniciação, que inicia uma resposta das personagens;

3. Essa resposta interna, ou seja, as reações no plano mental das personagens, motivam um plano sequência;

4. Dessa reação, surge um plano interno, ou seja, um planejamento das ações em resposta ao evento de iniciação; 
5. Ocorre a aplicação do plano, por meio de uma tentativa;

6. Essa tentativa resulta em uma resolução com consequências;

7. Essa consequência pode iniciar uma reação, que pode ser um novo evento de iniciação de outro episódio.

Além disso, em relação aos conteúdos, foram consideradas as categorias construídas $a$ posteriori de representação, ou seja, a prática de "construção de significados por meio de signos e linguagem" (DU GAY et al., 1997, p. 24). A partir de análise textual discursiva foram categorizadas: as representações antagonista/sincrética do Bem e o Mal e a relação humanonatureza presentes nas estórias. Essas categorias podem auxiliar na compreensão dos diferentes níveis que o universo das crianças pode influenciar no processo de produção da DC. Nesse trabalho, a estrutura e conteúdo das estórias foram consideradas como elementos constituintes do elemento representação, do circuito de cultura, apresentado anteriormente.

Para a compreensão da participação técnica/estética das crianças na cocriação de mídias, as análises focaram nas negociações e nos processos de manuseio e tomadas de decisão relativos aos equipamentos e locais de gravação, tanto de áudio quanto de vídeo. Além disso, os elementos estéticos (como as mudanças de enquadramento, decisões de como as estórias seriam apresentadas) também integraram as análises desse modo de participação.

Por fim, na participação identitária foram investigados os episódios em que se observou elementos para discutir a questão da identidade individual e coletiva.

Nessas perspectivas, o capítulo seguinte é destinado aos resultados dos dados obtidos, bem como as discussões que emergem das interações com os referenciais teóricos dos capítulos anteriores. 


\section{Resultados e discussão}

Tendo em mente as questões norteadoras desse trabalho, que visa compreender os modos de participação das crianças no processo de construção e apresentação de estórias enquanto prática de DC, bem como ampliar o conhecimento sobre as possíveis contribuições e limitações da Participação Infantil na Divulgação Científica, este capítulo se destina à discussão dos dados construídos a partir dos registros das ações educativas do projeto "Reintrodução do papagaio-de-peito-roxo (Amazona vinacea) no Parque Nacional das Araucárias, SC”. As ações educativas foram analisadas a partir dos referenciais teóricos apresentados anteriormente, considerando-se as perguntas de pesquisa. Assim, por meio da triangulação entre os dados provenientes dos registros audiovisuais, observações registradas no caderno de campo, produtos obtidos e retomando os objetivos desta pesquisa, buscou-se responder os seguintes questionamentos:

- Que modos de participação das crianças foram possíveis nas ações investigadas?

- Quais os principais desafios encontrados na promoção da participação das crianças durante o processo de coprodução de mídias de DC?

Vale lembrar que apesar das ações terem seguido etapas planejadas igualmente semana a semana, adaptações foram necessárias devido às características específicas e diferenças nas rotinas e dinâmicas entre as escolas, turmas e mesmo dentro das mesmas turmas quando abordadas em momentos diferentes da rotina escolar.

Como descrito anteriormente, as ações educativas analisadas tiveram como eixo centralizador narrativas que foram construídas ao longo do projeto e posteriormente deram origem às dez estórias que foram transmitidas para a população local via rádio. Assim, um modo de participação das crianças no processo de cocriação ocorre quando suas ideias e propostas se fazem presentes nos produtos finais. Esse modo de participação pode se dar nos diversos elementos que compõe o produto, que, no caso das estórias (produção literária), podem ser: personagens e suas ações, cenários, estruturas narrativas, entre outros elementos. No caso da radionovela e dos vídeos (produção audiovisual), somam-se os aspectos técnicos e a estética final dos produtos. Além dos modos relacionados com os produtos materiais do projeto, outra forma de participação das crianças foi observada nas relações entre as próprias crianças e entre estas e os adultos envolvidos (pesquisador e professores), em especial durante os momentos de tomada de decisão coletiva. 
Dessa forma, percebe-se a emergência, durante o processo analítico, de quatro principais modos de Participação Infantil, aqui denominados de participação: (1) contextualizada; (2) simbólica; (3) técnica/estética e; (4) identitária. A seguir, serão detalhados cada um desses modos de participação.

\subsection{Participação contextualizada}

Ao participarem das ações, as crianças da região do Parque Nacional das Araucárias trouxeram diversos elementos presentes em sua rotina e de seus familiares. A esse modo deuse o nome de participação contextualizada, no qual foram observados elementos relativos tanto ao contexto local, quanto das culturas da infância.

Durante a criação das estórias, elementos do contexto local das crianças se mostraram presentes, aparecendo no produto final, seja na radionovela ou no audiovisual, por meio das personagens e suas ações. A começar pelo próprio papagaio-de-peito-roxo, as crianças demonstraram conhecimento básicos sobre suas características biológicas e comportamentais, presentes em suas vidas de alguma forma.

\footnotetext{
Pesquisador: E aí, o que que a gente sabe sobre esse papagaio? Qual o nome dele?

Criança 1: Papagaio-peito-roxo

P: Papagaio-de-peito-roxo, exatamente. E o que mais que a gente sabe?

O que que ele come?

Criança 2: Semente

P: Semente!

C2: Minhoca

P: Minhoca? Minhoca ele não gosta muito não...

C1: Pinhão!

P: Pinhãão, ele come bastante pinhão! (...) E onde que ele vive?

Crianças: Na natureza... Na floresta.
}

(Grupo 4, Episódio 1)

Apesar da pequena população de papagaios-de-peito-roxo reintroduzidos na região, a forte presença do Instituto Espaço Silvestre auxilia em uma maior percepção à presença da ave no local.

Para além do papagaio-de-peito-roxo, outros elementos como os periquitos, maitacas, tucanos, pica-paus, veados, gaviões, araucárias e cachoeiras também são presentes no contexto dessas crianças. Nesse sentido é relevante também ressaltar as diferenças regionais para os nomes de alguns seres. No caso das crianças de uma escola, a grafia correta para a maitaca- 
verde é baitaca, utilizada em sua estória. Já em outras narrativas, mexerica é vergamota e a araucária é tratada como pinheiro ${ }^{28}$.

Pensando nos elementos morfológicos das culturas da infância o brincar se mostra presente em oito das dez estórias. Além do jogo, as personagens cantam, dançam e festejam, demonstrando outros elementos lúdicos incluídos nas narrativas.

Quando acordaram foram brincar na floresta com os amigos e aproveitaram para pegar as flores. Deram as flores para a mãe deles.

Os passarinhos e o Monstro de Ferro (E7)

Como discorrido nos capítulos anteriores, na perspectiva histórico-cultural, pode-se considerar que a atividade criadora da imaginação tem como ponto de partida a realidade (VIGOTSKI, 2014). Dessa forma, os demais produtos da imaginação são compostos de elementos reais obtidos ao longo da história dos sujeitos. No caso destas crianças, sua realidade é o entorno do Parque Nacional das Araucárias, as brincadeiras, os animais ali encontrados e as narrativas às quais são expostas. Durante o processo de criação de estórias, esses elementos são reorganizados na imaginação das crianças, retornando à realidade na forma de uma narrativa. Essas características regionais, tanto na diversidade biológica quanto na variação linguística, juntamente com as práticas infantis, auxiliam em uma maior caracterização, construindo uma estória composta não só pelas vozes das crianças, mas também por seus contextos e rotinas. As personagens não são apenas animais, mas as próprias crianças e sua identidade representadas nessas estórias. Vale ressaltar que na participação contextualizada de crianças na Divulgação Científica, não é possível separar tão fortemente conhecimentos mais voltados ao local geográfico e os conhecimentos mais presentes na infância, uma vez que há relação direta e dialética entre esses dois elementos. O brincar das crianças é recheado pelos objetos e conhecimentos de onde vivem, assim como suas brincadeiras fazem parte da história e cultura do local em que vivem.

No âmbito da regulação, ou seja, normas, regras e convenções explícitas ou implícitas para o processo de produção e troca de significados da DC (DAVIES; HORST, 2016), é possível observar a atuação de múltiplas instituições e organizações regulando a prática analisada. Como a atividade visava atender às diversas demandas do projeto de reintrodução do papagaio-de-peito-roxo e do Instituto Espaço Silvestre, do pesquisador, da rádio local, das

\footnotetext{
${ }^{28} \mathrm{Na}$ região é comum se referir à araucária como pinheiro e ao pinheiro exótico como pinus.
} 
escolas e respectivas Secretarias de Educação, diversos níveis de regulação puderam ser identificados. Das condições pretendidas nessa atividade com as crianças, estava a presença de estórias narradas, tendo pelo menos um papagaio-de-peito-roxo como personagem. Entretanto, não é de interesse de nenhuma das organizações envolvidas (IES, PARNA, escolas, Secretarias de Educação, a Nossa Rádio 100.7FM e os pesquisadores) divulgar estórias com temáticas que incentivem o tráfico, apreensão e caça de animais silvestres. A aprovação de temas pelos adultos torna-se uma restrição ao conteúdo das estórias e, portanto, um modo de regulação.

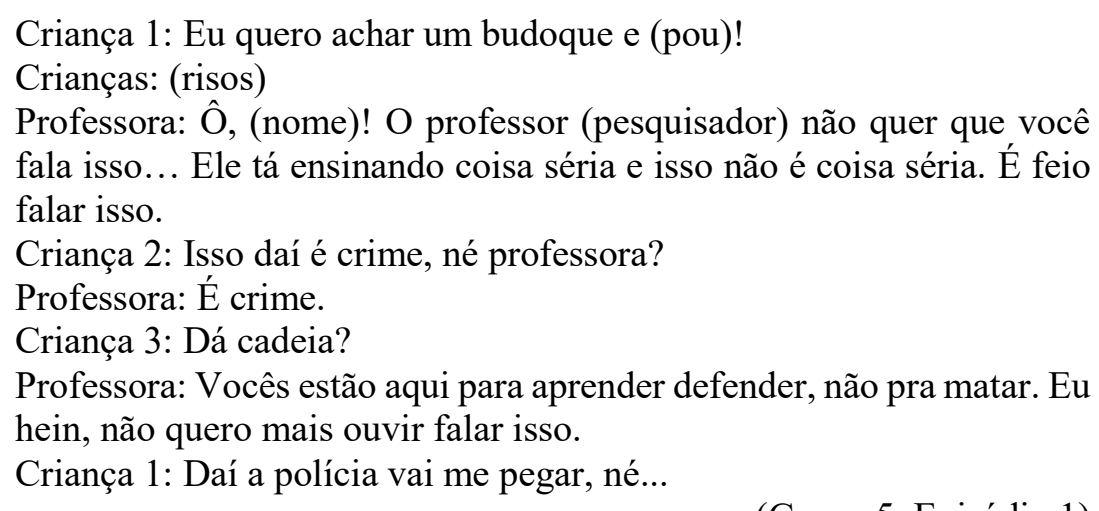

Apesar disso, nota-se que há uma tradição de brincadeiras com estilingues, caça e de papagaios engaiolados na região. Isso aparece tanto em conversas com as crianças quanto nas estórias, apresentadas de formas diferentes em cada caso. Durante as conversas, em diversos momentos, as crianças retomam esse tema, de maneira naturalizada e em tom recreativo, relatando já terem tido papagaios, matado animais com estilingues ou conhecerem alguém que tenha feito.

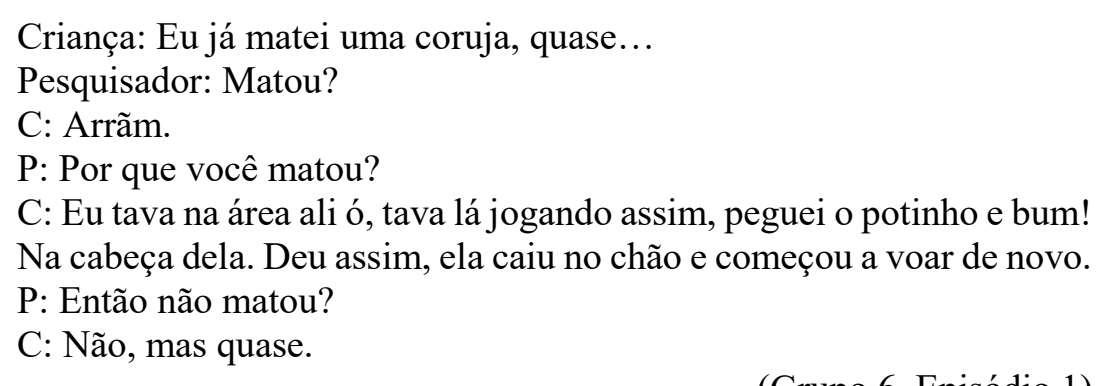

Já nos momentos voltados para a criação da estória, as falas tenderam a retratar caçadores e pessoas que maltratam e/ou apreendem papagaios como vilões, com exceção do menino em "O papagaio e os amigos dele" (E10), que acaba se arrependendo e volta a ser amigo dos animais. Isso ajuda a revelar diversas normas presentes nas atividades realizadas, aparecendo mais forte a regulação dos temas no momento de criação das narrativas. 
Além disso, os animais exóticos existentes na região (javali, cavalo e pato) ou não (leão, tigre, elefante) se mostram presentes ao longo dos processos de cocriação das estórias, apesar da solicitação do pesquisador para que se trabalhasse com a fauna local. Apesar de ser uma regra explicitada em diversos momentos, houve negociação com as crianças e abriu-se uma exceção para que animais exóticos presentes na região fizessem parte da estória uma vez que eram temas constantes da rotina dos moradores locais. Assim, como discutido anteriormente, as dimensões presentes no circuito da cultura não interagem em vias de mão única, mas sim se transformando mútua e dialeticamente (DU GAY et al., 1997). A regulação proposta pelo pesquisador tinha como objetivo a promoção da identidade das crianças por meio do uso da fauna local durante a construção de suas narrativas. Apesar disso, a identidade das crianças está relacionada com muitos outros elementos para além da biodiversidade local, sendo a atividade rural e a pecuária muito presente nas rotinas dessas crianças. Dessa forma, assim como a regulação foi capaz de ocultar alguns elementos da identidade das crianças nos produtos finais (como as brincadeiras com budoque), a própria identidade das crianças transformou a norma inicial e, consequentemente, uma parte do processo regulatório.

\subsection{Participação simbólica}

Além dos conteúdos serem diretamente afetados pelos contextos das crianças participantes, um modo de participação presente durante os processos de coprodução analisados está na forma que os produtos assumem quando são construídos em parceria com esses sujeitos. No caso da ação investigada, a escolha por se trabalhar com a produção e contação de estórias teve dupla intencionalidade: pela formação e interesse do pesquisador em contação de estórias; e por ser um elemento presente nas culturas da infância. Dessa forma, ao participar da cocriação de produtos e conhecimentos, entende-se que as crianças podem atribuir regras e estruturas dos seus jogos e brincadeiras, participando das ações de modo simbólico. Como discutido nos capítulos anteriores, um elemento muito presente nas culturas da infância é a brincadeira de faz-de-conta, também chamada de jogo simbólico por Vygotsky $(1994 ; 2014)$ e por Sarmento (2003). Nessas brincadeiras, as crianças constroem e compartilham significados sobre o mundo em que elas vivem, representando suas regras e seus elementos por meio dos processos imaginativos. Dessa forma, em ações que envolvem processos de cocriação de produtos e conhecimentos, este é um importante modo de participação das crianças. 
Para uma maior compreensão desse modo de participação (simbólica) das crianças, o foco se dará nas diferentes formas de representação presentes nas estórias e nas mídias audiovisuais produzidas. Por meio da transcrição das estórias (APÊNDICES 1-10), em conjunto com os registros audiovisuais dos processos de produção, foi possível interpretar as representações, ou seja, "os modos pelos quais usamos sinais para criar e comunicar significados sobre um fenômeno" (DAVIES; HORST, 2016, p. 17) presentes nos textos construídos com as crianças. A partir dos dados analisados, observa-se que diferentes elementos podem fomentar ou inibir as representações nas estórias. O primeiro deles, bastante evidente, está relacionado com a estrutura da narrativa.

A estrutura das estórias influencia em sua complexidade, bem como na quantidade de tensões existentes em seu enredo e, portanto, seu conteúdo. A partir do esquema de estórias (STEIN; GLENN, 1975) pode-se compreender o esqueleto base de uma estória como uma série de eventos que geram respostas nas personagens. Das dez estórias analisadas, foi possível identificar dois grupos diferentes: estória-cenário e estória com episódios.

Em "Papagaio Rico e seus amigos" (Apêndice 5) é observada uma estrutura descritiva, sendo a mais simples dentre todas as narrativas produzidas. Seu enredo não possui nenhum episódio e as personagens são apenas descritas em seu ambiente (cenário) e brincam juntas, sem eventos de iniciação nem problemas a serem resolvidos.

(...) Era um lugar lindo cheio de árvores!

Nesse lugar estava o Periquito Chico, o Tucano Tuco, o Porquinho Vitor e o Cavalo Trovão. Todos brincavam de pega-pega na floresta, muito felizes.

O Periquito Chico era lindo, de cor amarela. O Tucano Tuco era preto com vermelho e bico amarelo. Adorava voar pela floresta. (...)

Papagaio Rico e seus amigos (E5)

A falta de tensões acaba limitando a produção de significados, pois não há valores envolvidos devido à ausência de escolhas e tomadas de decisão. Dessa forma, não ficam explícitas as questões morais e outras visões das crianças quanto às ações das personagens. Apesar da estrutura simplificada, algumas representações se mostram presentes e serão discorridas a seguir.

Com a presença de episódios, ou seja, eventos de iniciação em que as personagens respondem através de ações (STEIN; GLENN, 1975), as estórias passam a apresentar tensões ao longo de sua narrativa. 
De repente, chegou um caçador, que queria sequestrar os papagaiosde-peito-roxo. Mas tinha dois do bando: Chico e Chica, que lutaram pela liberdade de seus amigos. (...)

Papagaios Chico e Chica (E3)

Esses dilemas são um importante elemento para a análise dos valores presentes nessas estórias. A promoção de estórias com estruturas completas, com episódios e consequências, demanda uma tomada de decisão das personagens, podendo explicitar assim algumas concepções e valores das crianças em relação aos temas propostos. No caso das ações de DC para conservação, essa estratégia de trabalho pode auxiliar na promoção de debates sobre os valores e atitudes presentes nas questões sociocientíficas. Em estórias sem episódios, se descrevem personagens e seu ambiente, o objetivo é limitado à promoção de conhecimentos conceituais de diferentes espécies e ambientes (características de animais em extinção e suas relações ecológicas). Já em narrativas completas, como as de tradição oral, diferentes visões de mundo se encontram e se confrontam, colocando em jogo diversas possibilidades de interpretação. Por meio dessa iniciativa, garante-se espaço para que as crianças possam participar do processo criativo, incorporando seus elementos simbólicos no produto final.

Um outro elemento analítico importante para se compreender as representações, em conjunto com a estrutura das estórias, são as diferentes relações entre o Bem e o Mal existentes nas narrativas. Quando solicitadas que compartilhassem estórias tradicionais, as crianças demonstraram conhecimento de contos clássicos, dentre eles: “Chapeuzinho Vermelho" e "João e o pé-de-feijão". É notável a presença das entidades do Bem (João, Chapeuzinho Vermelho e sua família) e do Mal (Lobo Mau, Gigante) nesses tipos de contos de fada, sendo objeto de estudo para diversas escolas do pensamento.

Partindo de uma abordagem psicanalítica, Bettelheim (2002) defende que a visão maniqueísta (presente nas estórias pela ocorrência de opostos que não se submetem nem se transformam diante do outro) é uma ferramenta para as crianças atribuírem significados e uma maneira prática de organização diante do caos que é a descoberta do mundo e de si mesmas. Para o autor, esse caráter unidimensional das personagens, no qual uma personagem ou é completamente má ou é completamente boa, ajuda as crianças a ordenar seus próprios sentimentos complexos cada qual em seu lugar.

Ela (a criança), como todos nós, está a todo momento num tumulto de sentimentos contraditórios. Mas enquanto que os adultos aprenderam a integrá-los, a criança é esmagada por estas ambivalências dentro de si mesma. Experimenta a mistura de amor e ódio, desejo e medo dentro 
de si mesma como um caos incompreensível. Não pode-se orientar sentindo-se num só e mesmo momento boa e obediente, má e rebelde, embora o seja. Dado que não pode compreender estágios intermediários de grau e intensidade, as coisas ou são tudo luz ou tudo escuridão. Uma pessoa ou é só coragem ou só medo; a mais feliz ou a mais miserável; a mais bela ou a mais feia; a mais esperta ou a mais burra; a gente ou ama ou odeia nunca algo intermediário. (BETTELHEIM, 2002, p. 78-79)

Já Durand (2012), com uma visão vinculada à escola do imaginário, considera que os arquétipos que dão origem material aos contos, lendas e mitos possuem punções diurna e noturna, a primeira caracterizada pelos opostos, pela separação e a última pela mistura e aproximações. Dessa forma, os símbolos heroicos e de cisão, como as armas, espadas e guerras são elementos que impulsionam o regime diurno, no qual é possível notar a presença dos princípios de exclusão, contradição e identidade. Já os princípios de síntese, sincretismo ou mesmo de confusão são presentes no regime noturno. $\mathrm{O}$ autor ainda expande as análises a aspectos culturais menos voltados à tradição oral, atribuindo às punções diurnas do imaginário o campo da política e mesmo da ciência, em especial às áreas com fortes tendências positivistas e demasiadamente cartesianas (DURAND, 2012).

Das dez estórias analisadas, o Bem e o Mal estão presentes em nove ${ }^{29}$ delas e a relação estabelecida pelas crianças entre eles foi compreendida em pelo menos dois atributos: o antagonismo e o sincretismo.

Nas estórias que apresentam uma visão antagonista, o Bem e o Mal são duas entidades igualmente poderosas, porém opostas, representadas por uma ou mais personagens em conjunto. Foram consideradas estórias dessa natureza: “A floresta escondida” (E1), "Tobi, Susu e a tempestade!" (E2), "Papagaios Chico e Chica" (E3), "Os passarinhos e o Monstro de Ferro" (E7), "A guerra contra os cortadores de árvores" (E8) e "O papagaio-de-peito-roxo e a Bruxa" (E9). Nessas narrativas, a disputa é presente, geralmente composta por apenas um episódio de guerra em que, ao final, o bem prevalece sobre o mal e não é possível a coexistência entre esses dois opostos, ocorrendo a morte ou expulsão dos perdedores.

Os animais jogaram a Bruxa no fogo! E viveram felizes para sempre.

O papagaio-de-peito-roxo e a Bruxa! (E9)

\footnotetext{
${ }^{29}$ Para esse elemento de análise desconsiderou-se a estória "Papagaio Rico e seus amigos" (E5) por não apresentar visões distintas.
} 
Durante a construção dessas narrativas, quando mediado pelo pesquisador, foram propostas alternativas ao enredo como forma de fomentar visões menos estereotipadas e dualistas.

Para Bachelard (2009), Durand (2012) e a escola do imaginário, essas estórias tendem às punções diurnas, no qual as imagens de separação e distinção são predominantes às de fusão e síntese. Essa forma de representação reforça uma visão maniqueísta de mundo, a existência de dois pensamentos diferentes que não coexistem no mesmo espaço e tempo e a tensão é finalizada somente quando uma das partes é eliminada. Apesar de representar essa visão simplificada e que à primeira vista pode parecer não apropriada para se trabalhar temas complexos, como a conservação de espécies, esse resultado revela características interessantes para as ações participatórias de DC. Dentre os diversos fatores que constituem a identidade está a diferença e as concepções que focam na separação.

Em “A guerra contra os cortadores de árvores” (E8), há uma clara divisão entre o grupo que representa o Bem, formado pelos animais da mata, os "Amigos dos Animais" e os homens de Catanduvas, e o grupo que representa o Mal, os cortadores de árvores de Concórdia. Essa estória se mostra interessante porque há a representação de uma dualidade do ser humano, que pode ser bom ou ruim, e a identificação das crianças em relação às personagens que representam o Bem. A descrição dos “Amigos dos Animais" é semelhante à das crianças do grupo que criou essa estória (crianças da cidade de Ponte Serrada) sendo que essas se unem às outras personagens na proteção da mata. Nas outras estórias, o grupo de animais representam os seres do Bem e que, na maioria dos casos, protegem a natureza contra as forças do Mal, geralmente representadas por seres humanos.

Embora o antagonismo entre Bem e Mal esteja presente na grande maioria das estórias geradas, em fácil distinção entre quem representa o Bem e o Mal, as estórias com visão sincrética, que possibilitam o diálogo e a transformação dos diferentes tipos de personagens após suas tensões e conflitos, também estão presentes. Gera-se uma síntese otimista dessa relação, no qual todas as personagens convivem harmoniosamente ao final. "Os animais da mata" (E4), “O papagaio Dedé e o Dragão!” (E6) e “O papagaio e os amigos dele” (E10) se enquadram nessa categoria de estórias, tendo percursos diferentes, mas com finais parecidos.

(...) Naja os ajudou e a Onça saiu toda machucada. Assim, a cobra virou amiga deles e todos festejaram.

Muito tempo depois a onça voltou sem amigos e pediu perdão. 
Com o perdão dos animais, ficaram amigos e todos viveram felizes para sempre! (...)

"Os animais da mata" (E4)

Essas diferentes visões de Bem e Mal estão presentes nas culturas infantis nos contos, filmes e desenhos, sendo este resultado algo esperado, principalmente pela escolha em utilizar as estórias como ferramenta. Para além das regras provenientes dos universos adultos, como a limitação de conteúdos e as normas escolares, a participação das crianças na escolha dos temas retratados nas estórias acaba incorporando algumas convenções das culturas da infância. Conforme discorrido anteriormente, a maioria dos enredos construídos foram de estórias com a presença das entidades do Bem e do Mal, na maior parte de forma antagônica. Nelas, o Mal deve ser eliminado para que o Bem prevaleça. Esse tipo narrativo emergiu da interação entre a expectativa do pesquisador e a vontade das crianças. Tal resultado ajuda a ilustrar como a participação das crianças pode influenciar na construção das estórias, uma vez que essa visão antagonista de Bem e Mal é muito encontrada no universo infantil, sendo uma estrutura convencional da maioria dos contos tradicionais, como os apresentados por elas no primeiro encontro com o pesquisador (“Chapeuzinho Vermelho" e "João e o pé-de-feijão").

Apesar de também estar em contato com o universo dos contos de tradição oral, o pesquisador possui também regras de regulação dos saberes biológicos e éticos, compreendendo que a representação do Bem e do Mal é criticada dentro da Biologia. Jiménez (1998) discorre sobre a visão que crianças possuem sobre a existência de animais bons ou ruins, criticando esse tipo de concepção por ser obstáculo ao aprendizado de noções ecologicamente corretas de diversos animais. Esta crítica, entretanto, pode ser complementada sob diferentes perspectivas.

Ainda no Ensino de Ciências, a construção e discussão de atitudes e valores é presente, nessa área, em diversos documentos oficiais da Educação, como nos Parâmetros Curriculares Nacionais e na atual Base Nacional Curricular Comum $^{30}$, fazendo parte tanto do currículo formal de educação quanto em ações fora da escola. Neste sentido, as estórias podem exercer um importante papel, uma vez que contos de fada e fábulas são geralmente atrelados a um final moralizante. Não se discorda que uma visão moral de mundo antagonizada e formada por uma única resposta final seja um obstáculo ao ensino de ciências, ainda que em suas dimensões atitudinais. Porém, as estórias não necessariamente representam tal visão, estando presente

${ }^{30}$ Disponível em < $\underline{\text { http://basenacionalcomum.mec.gov.br/> }}$, acesso em 27 jan 2018. 
nesta pesquisa e em diversos contos tradicionais alternativas a tal polarização (BETTELHEIM, 2002). Neste sentido, concorda-se com Rubira, que diz que:

Eu já não acreditava naquela bobagem de moral da estória que encontramos nos finais de muitas fábulas e contos de fada, para mim isso sempre soou desagradável como o ato de se explicar uma piada ou de se dar a resposta de uma charada que mal se terminou de contar, sem que possamos pensar sobre ela e tentar decifrá-la. No entanto, não existe nada mais prazeroso do que se descobrir a resposta de uma charada sem que ninguém nos precise dizer qual é. Melhor ainda é descobrir uma outra resposta possível, para aquela mesma charada que nos fizeram, para a surpresa de um perguntador metido a sabido e para nosso próprio deleite. (RUBIRA, 2006, p. 21-22)

Complementa-se então a discussão de Jiménez (1998) sem desconsiderar suas proposições. Para além das questões de aprendizagem de características ou de visões negativas dos animais, essa possibilidade de significação da estória e do mundo, das múltiplas interpretações e de várias respostas para diversos problemas, pode se mostrar uma potencial ferramenta para as questões de identidade e respeito às diferenças, bem como na proposição de reflexões sobre dilemas éticos. Para isso, entretanto, é necessário pensar em estórias que possibilitem essas múltiplas respostas, dar liberdade de interpretação às crianças. Dessa forma, os estudos sociais da infância se mostram relevantes tanto para o planejamento do trabalho quanto para a compreensão dos materiais produzidos pelas crianças.

Nesta perspectiva de ação pautada nos estudos sociais da infância, a forte influência da representação antagonista do Bem e do Mal nas estórias construídas não é um resultado inesperado. Essa representação faz parte das mais diversas formas de imaginário como: religiões, contos, lendas e ideologias (DURAND, 2012). No universo das crianças, estão presentes em filmes, quadrinhos, desenhos animados e contos de fada, sendo parte de suas brincadeiras também. Somado a isso, as crianças possuem uma forma de transformar o universo adulto em brincadeiras incorporando elementos de sua própria cultura. Por exemplo, quando brincam de faz-de-conta, as crianças não copiam passivamente o que os adultos fazem, trazendo para esse jogo suas próprias regras ${ }^{31}$. Dessa forma, a participação infantil nas tomadas de decisões nas ações de divulgação não resulta em uma estória cujos conteúdos pré-determinados pelos adultos são meramente repetidos pelas crianças.

\footnotetext{
${ }^{31}$ Corsaro (2009) propõe o termo reprodução interpretativa para esse fenômeno.
} 
Além dos dois elementos analíticos já citados (estrutura da estória e antagonismo entre Bem e Mal), observa-se que a relação ser humano e natureza adquire um papel relevante para o entendimento das representações nas estórias infantis.

Um pouco menos evidente do que o antagonismo entre Bem e Mal, a relação humanonatureza pode ocorrer de diferentes formas. A mais comum entre as estórias, é a representação do ser humano separado da natureza. Muito relacionadas com a perspectiva antagonista de Bem e Mal, essas estórias possuem uma visão do ser humano representando o Mal a ser combatido, um inimigo dos animais e seu ambiente (que representam o Bem). Esse grupo é composto pela grande maioria das estórias e apenas duas das dez narrativas não possuem tal representação.

Em algumas dessas estórias, os humanos representam o Mal na forma de caçadores, cortadores de árvores ou pessoas que aprisionam papagaios, sendo expulsos ou excluídos por meio da fuga dos animais para um local escondido.

Era uma vez, Tobi e Susu. Estavam conversando em sua casa quando um lenhador veio e derrubou sua casa. (...)

Encontraram atrás de uma cachoeira uma caverna, onde todos iriam morar juntos. Ali era seguro, não vinha tempestade, ninguém conseguia achar.

Ali moraram todos juntos: Pintadinho, Pipito, Tutu, Beija-Flor, Nevinha, Tobi, Susu, Rosa, Roxinho e Bibi.

Viveram felizes para sempre!

Tobi, Susu e a tempestade! (E2)

Já em outras estórias, o Mal é representado por criaturas fantásticas, como um monstro de ferro ou uma bruxa. Apesar disso, os seres fantásticos realizam ações humanas consideradas más, como o corte de árvores e aprisionamento de animais silvestres, tendo representações bem semelhantes às demais estórias dessa categoria.

Foram dormir na casa deles no ninho. O papagaio dormia nas árvores, em um tronco lá no céu. (...) Foram passear, mas se perderam no caminho e viram uma coisa no ar: era um monstro! Ele era de ferro! Tentaram jogar pedras mas não conseguiram.

Voltaram para casa e ela estava toda quebrada. O Monstro de Ferro que quebrou (...)

Os passarinhos e o Monstro de Ferro! (E7)

Além da representação do Mal, há estórias em que os humanos não aparecem, estando afastados, mas sem representar um inimigo. Nesse sentido, se aproxima de visões naturalistaromântica e naturalista-reducionista do meio ambiente, visto como um conjunto de elementos 
naturais de ecossistemas e representado de forma intocada, ressaltando-se sua beleza (URSI et al., 2013).

São muito amigos, brincam juntos e adoram a floresta, porque lá tem: árvores, rios, lama e muitos animais. E vivem felizes na floresta. (...)

Papagaio Rico e seus amigos (E5)

A representação nessas estórias se assemelha ao final dos enredos que representam os humanos enquanto a entidade do Mal a ser combatido e eliminado, excluindo sua presença no ambiente da floresta. Este é o final feliz nessas estórias: uma relação harmônica entre os demais seres vivos que compõem a floresta e sem a presença humana caçando e/ou destruindo seu habitat.

Apesar desta representação afastada entre ser humano e natureza, durante a construção da estória foi possível observar maior identificação das crianças pelos animais do que pelos humanos. Esse sentimento de proximidade com os protagonistas animais e seu lar (a mata, a floresta) podem ser compreendidos tanto pela facilidade em se projetar nos personagens bons (BETTELHEIM, 2002) quanto com outras questões de identidade, dimensão que também compõe o circuito de cultura.

Como dito, oito estórias trouxeram representações da relação humano/natureza pautadas no distanciamento entre seres humanos e o ambiente natural. Nas duas outras estórias, entretanto, os humanos aparecem como iguais aos animais podendo ser um amigo e brincando junto, em uma perspectiva do humano integrado à natureza.

Em "O papagaio e os amigos dele" (E10), o menino Fábio, apesar de se corromper ao longo da estória, é amigo dos animais e parte do grupo, sendo perdoado no final.

Era uma vez um papagaio-de-peito-roxo chamado Quiqui. Ele comia as sementes de frutas e gostava de brincar com seus amigos: o Jacu Chico-rico, o Cachorro Totó e o Menino Fábio. Fábio gostava muito de animais e de quem ele gostava mais era do Quiqui. Um dia eles saíram para passear. (...)

O papagaio e os amigos dele (E10)

Nesta estória, não há grande diferenciação entre Fábio e outros animais, apesar do menino ser o solucionador de problemas, todos brincam e passeiam juntos, pertencendo ao grupo. 
Em "A guerra contra os cortadores de árvores" (E8), os humanos aparecem sob a forma de três grupos diferentes, um representando o Mal e os outros dois representando o Bem, juntamente com os animais e a floresta.

Era uma vez um Tucano Paçoquinha, amigo do Paulo, um papagaiode-peito-roxo.

Eram amigos dos "Amigos dos Animais", um grupo de mil crianças de Ponte Serrada que gostavam muito dos dois. (...)

De repente, homens de Concórdia começaram a cortar as árvores e os animais declararam guerra! (...)

Para ganhar a guerra, os pássaros fizeram arma de tambor e atiraram nos homens.

Além deles, outros pássaros e homens de Catanduvas vieram ajudar.

A guerra contra os cortadores de árvores (E8)

Nesta estória e no caso do menino Fábio (E10), a relação humano-natureza se mostra integrada, de maneira independente das representações do Bem e do Mal. Ao mesmo tempo e em que os homens de Catanduvas e os Amigos dos Animais pertencem à natureza de maneira benéfica, o menino Fábio é amigo dos animais, pertence ao grupo, mas corrompe-se no meio da estória.

Tabela 3. Síntese das representações presentes nas estórias.

\begin{tabular}{|c|c|c|c|c|c|}
\hline $\mathrm{E}$ & Título & Grupo & Estrutura & $\begin{array}{c}\text { Relação entre o } \\
\text { Bem e o Mal }\end{array}$ & $\begin{array}{l}\text { Relação humano- } \\
\text { natureza }\end{array}$ \\
\hline E1 & A floresta escondida & \multirow{2}{*}{1} & Estória com episódios & Antagonismo & Separado \\
\hline E2 & Tobi, Susu e a tempestade! & & Estória com episódios & Antagonismo & Separado \\
\hline E3 & Papagaios Chico e Chica & \multirow{2}{*}{2} & Estória com episódios & Antagonismo & Separado \\
\hline E4 & Os animais da mata & & Estória com episódios & Sincretismo & Separado \\
\hline E5 & $\begin{array}{l}\text { O papagaio Rico e seus } \\
\text { amigos }\end{array}$ & \multirow{2}{*}{3} & Estória-cenário & - & Separado \\
\hline E6 & $\begin{array}{c}\text { O papagaio Dedé e o } \\
\text { Dragão! }\end{array}$ & & Estória com episódios & Sincretismo & Separado \\
\hline E7 & $\begin{array}{l}\text { Os passarinhos e o Monstro } \\
\text { de Ferro! }\end{array}$ & 4 & Estória com episódios & Antagonismo & Separado \\
\hline E8 & $\begin{array}{l}\text { A guerra contra os cortadores } \\
\text { de árvores }\end{array}$ & 5 & Estória com episódios & Antagonismo & Integrado \\
\hline
\end{tabular}




\begin{tabular}{|c|c|c|c|c|c|}
\hline E9 & $\begin{array}{c}\text { O papagaio-de-peito-roxo e a } \\
\text { Bruxa! }\end{array}$ & 6 & Estória com episódios & Antagonismo & Separado \\
\hline E10 & O papagaio e os amigos dele & 7 & Estória com episódios & Sincretismo & Integrado \\
\hline
\end{tabular}

Fonte: o autor (2018).

Com isso, as representações presentes nas estórias relacionam-se, ainda que parcialmente, a algumas representações de mundo que as crianças envolvidas no processo de produção possuem. Entretanto, as representações relacionadas com valores das crianças, como as possibilidades de relação entre o Bem e o Mal ou entre humano e natureza, somente foram manifestadas ao serem trabalhadas estórias com maior nível de complexidade. No caso em que não há episódios, como em "Papagaio Rico e seus amigos" (E5), a ausência de situações de tensão e conflito pode ser uma barreira à manifestação desses valores. Nesse sentido, fica ressaltada a relevância do referencial do "Esquema de Estórias" (STEIN; GLENN, 1975) para o planejamento e análise das ações, por possibilitarem que esses temas surgissem nos processos criativos das crianças. Dessa forma, para promover esse modo de participação das crianças, deve-se compreender como que as representações simbólicas se apresentam nos elementos morfológicos das culturas da infância como as estórias, jogos e canções.

\subsection{Participação técnica/estética}

Durante o processo de cocriação de mídia, são colocados em movimento diversos conhecimentos além de seus conteúdos. Aspectos técnicos específicos da mídia trabalhada e elementos estéticos como: enquadramento, estilo vocal de narração, efeitos sonoros e escolha de cenários são integrados às negociações e aos produtos finais. Assim, em ações de DC participatórias voltadas à cocriação de produtos, as formas de se participar técnica e esteticamente devem ser levadas em consideração tanto no planejamento das práticas quanto em avaliações e pesquisas. No caso das ações investigadas, houve pouca ou nenhuma participação nos aspectos técnicos da produção das mídias audiovisuais, sendo que na maioria das turmas houve poucos momentos dedicados às questões técnicas de gravação de som e vídeo. Nas turmas em que houve tempo e estrutura para tal, as crianças foram convidadas a manipular os equipamentos, auxiliadas pelo pesquisador ou de maneira autônoma. 
Quando a ação era diretamente relacionada com os produtos finais, principalmente na gravação da narrativa, efeitos sonoros e de cenas de vídeo, foram utilizados equipamentos caros e com complexidade maior de manuseio. Nesses casos, a autonomia das crianças era reduzida, o que pode ter influenciado o potencial criativo do grupo. Entretanto, apesar das crianças não estarem ativamente envolvidas com as decisões técnicas de como as gravações aconteceriam, em um dos grupos foi possível promover a participação nas escolhas de locações e formas que os efeitos sonoros apareceriam em sua estória. Em "A floresta escondida" os efeitos sonoros foram propostos pelo pesquisador e decididos coletivamente.

Pesquisador: A gente pode gravar agora...

Criança 1: Lá fora...

P: Vamos pensar que outros sons podem ter nessa estória, além do som das pessoas falando.

Criança 2: Som do passarinho...

Criança 3: A Beca.

$\mathrm{C} 1$ : Eu faço o som do passarinho!

Criança 4: Podia ter o som dos animais?

P: O som dos animais, lá de fora? Será? Será que a gente consegue pegar uns passarinhos?

C2: Sim.

(...)

P: Bom, vamo pensar em como a gente faz... Ó, a gente pode fazer os passos do caçador na grama, que dá pra pegar com esse daqui (gravador de mão). Alguém vai lá, passa na grama assim...

$\mathrm{C} 2: \mathrm{Eu}$ !

C1: Eu!

P: Pode fazer a Sussurro correndo...

$\mathrm{C} 1$ : Eu faço a Sussurro correndo!

(...)

P: Pode fazer o som deles brincando e cantando, assim, todo mundo junto em uma roda. Que som que seria?

C3: Piu!

C1: Dar risada, felicidade... Carinho!

P: Pode ser, olha, tive uma ideia. A gente deixa o gravador no meio, vocês fazem uma roda e brincam em volta.

C2: Professor, não era eu que ia segurar o gravador?

P: O gravador? Pode segurar o gravador. Então você segura enquanto as pessoas ficam rodando.

C2: Sim.

(...)

P: O que mais que pode ter de som no nosso filme, na nossa estória?

C3: O som da fábrica?

P: Da fábrica? A gente tá no meio da floresta naquilo lá. Um som de jaula prendendo?

C1: Sim, fechando a porta!

P: Pode ser naquela porta de ferro ali!

(Grupo 1, Episódio 4a) 
Esse episódio exemplifica uma interação entre os conhecimentos técnicos do pesquisador em relação à produção da radionovela e das sugestões das crianças para atender a essa demanda. Dessa forma, apesar da proposta inicial ter sido feita pelo pesquisador, considerou-se que nesse caso, as crianças puderam participar das decisões envolvidas na escolha dos locais e na forma que aconteceriam as gravações. Tais conhecimentos das crianças em relação às possibilidades sonoras dos espaços de sua rotina estavam presentes no produto final.

De maneira semelhante, na gravação audiovisual, as crianças também puderam contribuir com as escolhas dos locais, enquadramento e manuseio dos equipamentos. Por apresentar um grande desafio técnico e logístico, a produção final da narrativa de maneira audiovisual foi construída coletivamente com as crianças apenas nas estórias "Tobi, Susu e a tempestade"32 (Grupo 1) e "O Papagaio e os amigos dele"33 (Grupo 7).

Pesquisador: Hoje, para falar a verdade, o trabalho que eu tinha pra fazer com vocês acabou, que era a estória. Mas a gente pode fazer outras coisas... Por exemplo, vocês querem fazer um vídeo?

Crianças: Sim!

P: Vou mostrar para vocês uma coisa, quer ver? Mostrar um vídeo ${ }^{34}$ que eu fiz com o terceiro ano, ficou bem legal, se vocês quiserem tentar fazer um parecido, pode ser com a estória de vocês ou pode ser com a estória...

(...)

C: Que legal!

P: Ficou legal?

C: Ficou.

P: A gente consegue fazer um mais legal do que esse?

C: Sim, ah, com certeza né, professor?

P: Então é assim, a gente pode fazer... Como que vocês querem fazer?

Pode ser com a estória que a gente fez...

C: Sim, com a estória que nós fizemos!

P: ... pode ser com outro texto que vocês queiram fazer agora.

C: (incompreensível)... que é melhor.

P: Com a que a gente fez? Pode ser, vamos lá então... Vamos preparar. Qual vai ser o fundo do vídeo? Eles fizeram com o fundo ali (aponta para uma parede da sala de leitura). Qual que vocês preferem?

$\mathrm{C}$ : Esse aqui, esse fundo preto!

P: Aqui? Pode ser, acho que fica bom.

(Grupo 7, Episódio 6)

${ }^{32}$ Disponível em $<\underline{h t t p s: / / w w w . y o u t u b e . c o m / w a t c h ? ~} \mathrm{v}=$ ps-a5h2-8Rk $>$, acesso em 12 ago 2019.

${ }^{33}$ Disponível em $<$ https://www.youtube.com/watch?v=XycnfYcAp68 $>$, acesso em 12 ago 2019.

${ }^{34} \mathrm{O}$ vídeo produzido por um grupo de crianças que não se interessou pela produção em formato de estórias. Não compõe o quadro analítico enquanto produto. 
A estética ${ }^{35}$ dos produtos também teve grande influência das crianças, mesmo nos casos em que não houve a intencionalidade por parte desses sujeitos. Inicialmente, a gravação seguiu a estrutura do vídeo mostrado, como exemplo: crianças em pé com enquadramento em plano médio/próximo ${ }^{36}$, narrando a estória criada e olhar direcionado para a câmera. No vídeo apresentado, uma das crianças se apresentava como o papagaio-de-peito-roxo, usando uma máscara de feltro. Após poucos minutos, as crianças revelaram sua vontade de usar as máscaras presentes na sala de leitura.

Criança 1: Ei, professor, eu queria usar máscara. Tem que usar máscara, professor.

Criança 2: Ô, professor, tem que usar máscara...

Professor: Se vocês quiserem usar máscara...

C2: A máscara, a máscaraa

P: Aí, ó! O Totó.

$\mathrm{C} 1$ : Nós tem o papagaio.

P: Cadê o menino? O papagaio tem aquela máscara que o... estava usando.

C1: Eu uso o do papagaio.

Criança 3: Cadê a máscara do Chico-Rico?

P: Tem um... Um urubu ali

Criança 4: Esse?

P: Não, esse é um tucano...

(Grupo 7, Episódio 6)

Dessa forma, ao longo do momento de gravação (aproximadamente trinta minutos), as escolhas das crianças variaram até que, ao fim, decidiram por encenar a estória em um teatro de fantoches enquanto uma das crianças narrava a estória para as demais sem aparecer em cena. Na montagem final, utilizou-se a narração prévia que foi transmitida via rádio como forma de vincular as duas produções.

Figura 8. Transformações estéticas em "O Papagaio e os amigos dele".
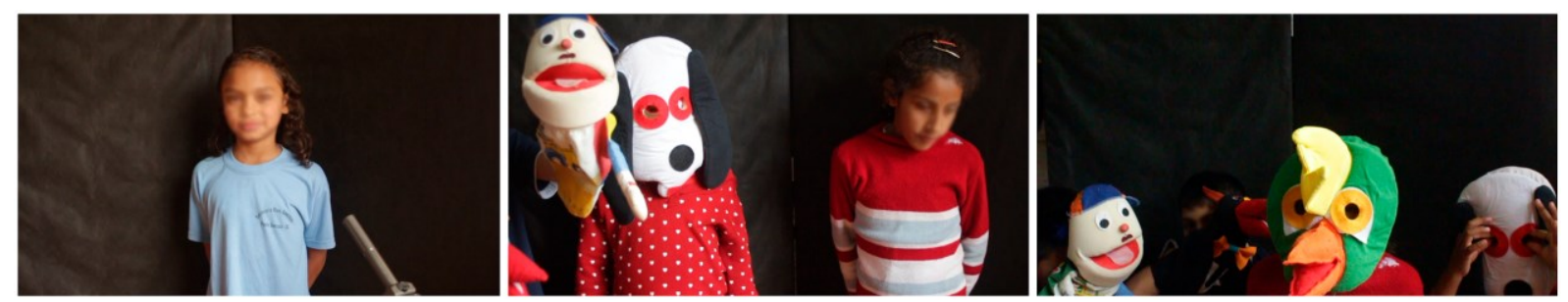

\footnotetext{
${ }^{35}$ Considerou-se nesse trabalho o sentido amplo da palavra (ESTÉTICA, 2019), envolvendo quaisquer elementos que de alguma forma estão relacionados com a beleza e o fenômeno artístico dos produtos finais.

${ }^{36}$ Respectivamente, sujeito enquadrado da altura do umbigo/do peito até a cabeça.
} 
Os enquadramentos estão em ordem cronológica da esquerda para a direita. A proposta inicial, com base no vídeo apresentado, variou até assumir sua forma final. Fonte: O autor (2017).

Já durante a produção do vídeo de "Tobi, Susu e a tempestade", o movimento se deu de forma contrária, com a ideia inicial dada pelas crianças do Grupo 1 e depois negociada com o pesquisador e pela assistente social responsável pelo grupo. Após a apresentação da proposta de produzir um material em forma de vídeo, uma das crianças sugere a construção de fantasias e o uso de máscaras para encenar a estória:

Criança 1: Eu já sei (...) cada um se disfarça, um é o lenhador e o outro... e subimos ali em cima, onde seria nossa mata. E aí nós achemos um toco né, e coloquemo e fingimos que aquele ali é o toco, né professor? (Uma das crianças corre para pegar uma caixa com máscaras de papel) Pesquisador: Gente, mas não sei se vai dar certo.

Assistente: Eu acho que não.

P: Eu acho que não vai dar certo essa história... Que outra coisa que a gente pode fazer?

A: Vocês podiam fazer, olha uma ideia de professora: cada um fazer um desenho de uma das cenas...

Crianças: Nãããão.

C1: Não, eu acho melhor a gente fazer ao vivo mesmo.(...)

P: Vamos pensar em outra forma porque eu acho que esse daí não vai dar tempo de fazer hoje...

(Grupo 1, Episódio 6b)

Ao longo de dez minutos de negociação, as crianças apresentam suas propostas como a criação de fantasias a partir da capa dos colchonetes para que a gravação ocorresse ainda no mesmo dia, que foram negadas por falta de tempo e materiais para a execução:

Pesquisador: Eu to tentando entender como é que vai fazer, se você me convencer que é uma boa ideia...

Assistente: Porque assim ó... vocês precisariam se fantasiar, precisariam fazer as fantasias com tempo. (...) Tinha que ter sido com tempo, nós fazemos fantasia. (...) Vocês têm meia hora para fazer, que está na hora do intervalo. (...)

Criança 2: Mas nós estava tentando fazer mas a senhora disse "nãão, vocês iam rasgar".

A: Mas tem de fazer, mas não vão rasgar a capa do colchonete vocês sabem que não dá para fazer furo ali.

(Grupo 1, Episódio 6b)

Após uma sugestão da assistente social, o grupo então tenta chegar a um consenso:

Assistente: Eu ia dizer pra vocês pegarem e acharem recorte e colagem e montarem a cena com colagem. Tem um monte de material para recorte e vocês achariam os personagens, montariam as cenas no papel... Aí ele (pesquisador) ia mudando. 
Criança 1: (pensativa, aponta para elementos nas paredes da sala). Ah lá, um passarinho, o Pipito... Ah lá, uma borboleta, o Dudu. E se a gente fizer... Pegar um personagem e colocar nesses palito (de churrasco) aí de coisa.

A: Mas o professor falou isso antes, essa ideia.

C1: Não falou. Falou de FANTOCHE, isso não é fantoche.

Pesquisador: É quase um fantoche, quando você faz um fantoche de papel o máximo que dá pra fazer é isso.

C1: Dá pra ser?

P: É uma boa ideia. E é mais viável do que fazer uma fantasia em meia hora.

C1: Eu só quero ver quem é que vai desenhar o Tobi e a Susu...

(Grupo 1, Episódio 6b)

Assim, o produto final se baseou em fantoches de mão e de papel, feitos a partir dos desenhos das crianças e encenados por elas nos arredores da escola (Figura 9).

Figura 9. Cenas de "Tobi, Susu e a tempestade".

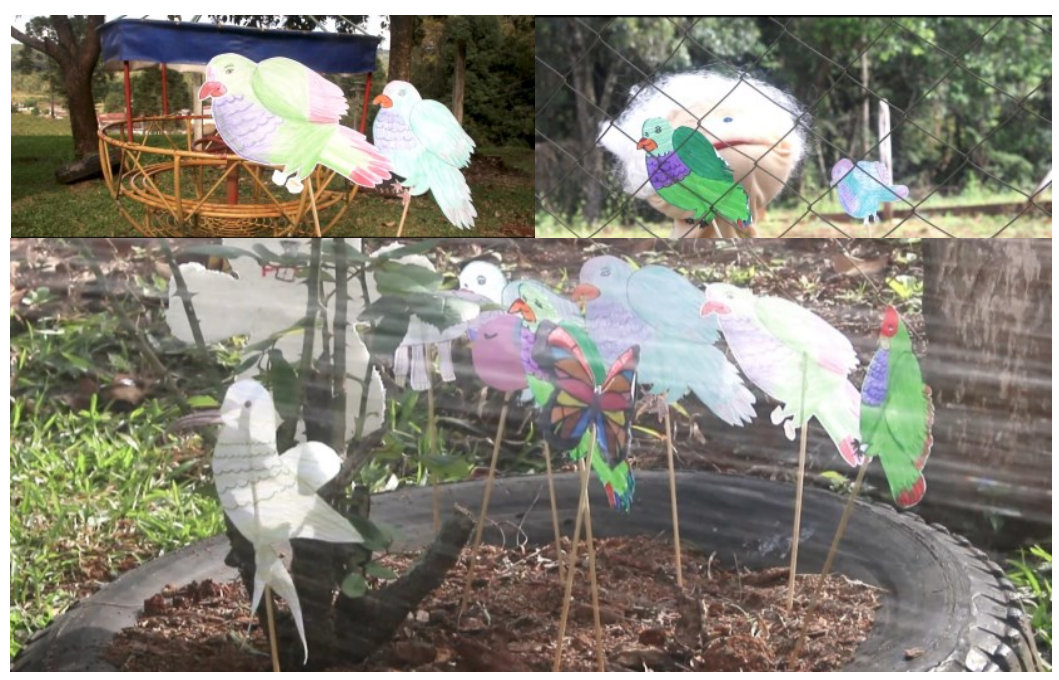

Fonte: O autor (2017).

Para além da estética visual dos produtos, a própria voz das crianças foi considerada parte deste modo de participação. As estórias construídas pelas crianças foram apresentadas por elas mesmas e seu produto carrega diversos significados, mesmo que inconscientemente, do universo desses sujeitos. O regionalismo presente na escolha das palavras, o sotaque característico da região e até mesmo a tonalidade da voz desses grupos de crianças carregam diversos significados. Assim como os elementos locais podem influenciar nos conteúdos transformados por meio da participação contextualizada também podem influenciar na expressão artística e na beleza do produto final por meio da participação estética. 
Uma das decisões tomadas durante o projeto era de evitar a leitura dos textos, uma vez que a estória lida é diferente da estória contada, assim como a estória encenada pode ser facilmente diferenciada da estória narrada.

O teatro é feito de movimento, podendo até dispensar as palavras pronunciadas se quiser, o movimento conta suas histórias. As próprias falas do texto teatral são impregnadas de movimento, elas parecem superlativar a movimentação de cena. Saberemos essa diferença se fecharmos os olhos e nos pormos apenas a escutar ambas as atividades, nossos ouvidos percebem se o que está sendo executado, ali diante de nós, trata-se de uma peça teatral ou da narração de uma história. Na narração, as palavras também gesticulam, tem movimento, mas seus movimentos precisam ser algo suave, não podem ser bruscos nem se sobreporem as palavras que irão soar e ressoar no ouvinte. A boa narrativa deve acontecer independente de qualquer material cênico ou sonoro que possa vir a enriquecê-la. Deve se bastar no olho no olho entre narrador e ouvinte e na voz que a materializa e a presentifica. Existe algo de intimidade na narração, algo de acolhedor e, na seriedade com que é recebida pelo público, está a alegria de fazer parte desse momento de ligação entre o indivíduo e a história (RUBIRA, 2006, p. 54).

Os textos que inicialmente foram lidos e gravados foram descartados por estarem demasiadamente presos ao ritmo próprio da leitura. Dessa forma, para a gravação, foram realizadas diversas estratégias, sendo a contação e recontação a mais efetiva. Por meio de uma narração inicial, frase a frase, realizada pelo pesquisador, a criança encarregada da gravação era convidada a refazê-la com sua própria voz e entonação. No caso da produção de "Tobi, Susu e a tempestade", esse processo foi realizado pela criança mais velha do Grupo 1, que criava e sussurrava simultaneamente aos colegas o que criava, com base na estrutura inicial da estória que havia sido registrada na lousa, para que fosse recontada ao gravador. Dessa forma, de todas as estórias, "Tobi, Susu e a tempestade" pode ser considerada a mais próxima de uma narrativa na concepção de Rubira (2006). Durante a gravação, a condução da atividade foi feita por essa criança mais velha, adotando técnicas semelhantes às do pesquisador para auxiliar as crianças menores na contação: narrava previamente uma frase para que as outras repetissem sem dificuldades de leitura. Entretanto, durante a facilitação feita pela criança, algumas frases não eram pré-acordadas dentro do grupo, sendo produzidas mentalmente pela criança mais velha com base no enredo. Essa forma de narração, sem um registro prévio de maneira escrita, resultou em uma estória mais próxima aos vícios e variações linguísticas daquelas crianças, tendo mais similaridade com uma comunicação verbalizada.

Era uma vez, Tobi e Susu. Estavam conversando em sua casa quando um lenhador veio e derrubou sua casa. Encontraram a coelhinha Nevinha. Pediram ajuda para encontrar uma nova casa. Conseguiram encontrar um toco e fizeram um ninho. 
Tobi, Susu e a tempestade (E2)

Por fim, cabe retomar a discussão dos estudos de mídia em relação à lacuna de participação, uma vez que a falta de acesso a equipamentos e meios de produção midiáticas representa um desafio na promoção da cultura participatória (JENKINS, 2006). Assim, formas de participação de cunhos técnicos e estéticos podem representar grande parte do tempo e atenção disponibilizada durante as ações de coprodução de mídias. Na pesquisa em questão, a promoção da participação de crianças nas decisões técnicas e estéticas só foi possível de ser realizada em dois grupos, uma vez que continham poucas crianças, em geral mais velhas. No caso do Grupo 1, os encontros ocorriam em dois períodos da semana, o que possibilitou que as crianças pudessem se familiarizar e manipular os equipamentos após algum tempo, inclusive fazendo-o de maneira autônoma durante a maior parte da produção de sua segunda estória. Assim, apesar de ser cercado de desafios, a promoção da participação técnica/estética pode aproximar as crianças do processo de cocriação à medida que tem potencial de promover a produção autônoma de mídias por parte delas.

\subsection{Participação identitária}

Durante todos os processos decisórios em relação aos produtos cocriados com as crianças, foi fomentada a discussão nos grupos como forma de promover a participação de todos os envolvidos. Nesse sentido, em alguns pontos de tensão, escolhas se fizeram necessárias e foram observados alguns dilemas entre decisões que priorizavam escolhas individuais e coletivas. Tais processos foram denominados nesse trabalho como participação identitária.

A questão da identidade está presente nas diferentes áreas de estudos que compõem as perspectivas teóricas dessa pesquisa. Nos estudos que conceituam a DC enquanto um fenômeno cultural (DAVIES; HORST, 2016), nas narrativas de tradição oral (BETTELHEIM, 2002) e nos estudos de mídia participatória (JENKINS, 2006; JENKINS et al., 2006; POTTER, 2017; STORNAIUOLO; THOMAS, 2017), a identidade é considerada um elemento de relevância para as práticas e pesquisas. Nos estudos culturais as representações são capazes de retratar a identidade de determinado grupo ou ajudar a construir e normatizar identidades novas (DU GAY et al., 1997). Quando aplicada ao contexto da Divulgação Científica, os estudos culturais buscam investigar as identidades envolvidas no meio científico-acadêmico que são compartilhadas bem como ajudar na compreensão de como as identidades do público leigo são 
influenciadas e construídas quando seus sujeitos estão engajados em ações e práticas de Divulgação Científica (DAVIES; HORST, 2016).

Nessa perspectiva, foram analisados episódios ao longo das ações educativas em que apareceram elementos relacionados com a questão identitária. Foram selecionados dois episódios específicos em que a questão da identidade foi considerada enquanto transformadora tanto dos elementos representados na estória e mídia produzidas quanto das dinâmicas e processos de cocriação do grupo.

No quinto episódio, presente na narrativa E2, observa-se a "diferença" torna-se elementos identitário central. A E2 foi construída por demanda da turma do Serviço de Convivência e Fortalecimento de Vínculos, programa que atua no contra turno de escolas, atendendo crianças com atividades extracurriculares. Devido à possibilidade de trabalho também nesse horário, a estória "A floresta escondida" (E1) foi trabalhada em ambos os períodos, sendo que, no contra turno (à tarde), duas crianças mais velhas (Crianças 1 e 2, Grupo 1, Episódio 1b) auxiliaram nas atividades. Como a estória foi trabalhada majoritariamente no período da manhã, sua estrutura inicial como nome das personagens e enredo já chegavam préacordadas no contra turno, reduzindo a participação das crianças mais velhas. Assim, o grupo da tarde (contra turno) optou por fazer uma segunda estória, incluindo essas crianças nas ações, desde a criação dos personagens.

Pesquisador: Bom, acabou aqui nossa estória (“A floresta encantada”) Criança 1: Fim!

Criança 2: Fazer a do PETI ${ }^{37}$, fazer a do PETI... (cantarolando)

P: Vamos fazer a do PETI?

$\mathrm{C} 2$ : Eu começo dizendo os nomes! O Bob vai ficar igual!

P: O Bob vai ficar igual? (Apaga os nomes da lousa)

$\mathrm{C} 1$ : Ô professor, porque o senhor apagou os nomes?

P: Não é uma estória nova? (inteligível)

C2: Não, Bob não, vai ser outro, (nome)!

C1: Rosa também vai ficar...

Criança 3: ... Tobi?

C1 e C2: TOBI! Tobi, Tobi!

P: Tobi e Bob...

C1: Tobi!!

C2: Tobi! Bob é feio... coitadinho, tá despenado.

(Grupo 1, Episódio 1b)

\footnotetext{
37 As crianças se referem ao Serviço de Convivência e Fortalecimento de Vínculos como PETI, devido a uma mudança recente na nomenclatura: até o ano de 2016, o contra turno nesta escola era parte do Programa de Erradicação do Trabalho Infantil (PETI).
} 
A identidade desse grupo se mostra diferente da turma da manhã, apesar de composto quase que pelas mesmas crianças. Esta diferenciação abriu a demanda pela produção de mais uma estória, criada totalmente pelo "PETI". Cabe ressaltar que o início da construção da narrativa por meio da escolha das personagens se deu por iniciativa das crianças, antecipando as ações do pesquisador. Além disso, a influência da primeira narrativa é presente durante a criação da nova, seja na aparição de personagens semelhantes (papagaios Bob e Tobi, protagonistas das estórias) ou pelo esforço em trocar os elementos para a construção de algo diferente. Mas é possível considerar que as mesmas crianças, interagindo dentro da mesma escola durante o mesmo projeto são dois grupos diferentes? Nesse entendimento é necessário compreender a questão da identidade enquanto relacional, ou seja, "a diferença será estabelecida por uma marcação simbólica, relativamente a outras identidades" (WOODWARK, 2014, p. 13). Em uma perspectiva não essencialista, a identidade pode se transformar ao longo do tempo, em parte, por meio de sistemas classificatórios ${ }^{38}$ que vão determinar o que pertence a determinados grupos e não a outros, diferenciando-os (WOORWARK, 2014). No caso do Grupo 1, a não participação das crianças mais velhas (C1 e C2) nas etapas iniciais da criação de "A floresta escondida" atribuiu às suas personagens uma classificação simbólica de diferença, de ser a estória de outro grupo. A afirmação do PETI enquanto diferente da outra turma aparece ao longo do processo de produção da estória, ajudando a reafirmar sua identidade enquanto um grupo.

Nas relações entre representação e produção, uma discussão emerge com a análise do processo de criação dessa narrativa. Em uma interpretação dos resultados, ou seja, das estórias em si e suas representações, é possível concluir que não há variação nas representações entre “A floresta encantada" (E1) e "Tobi, Susu e a tempestade" (E2). Em ambas, as visões do Bem e do Mal são antagônicas e o ser humano não pertencente à natureza. Estruturalmente são semelhantes, iniciando com um grupo de animais em uma condição de inocência, surpreendidos por um fenômeno em que uma parte deles acaba sendo capturada por um humano. No fim, a resposta em ambas é uma fuga para um local escondido, longe dos perigos, onde podem viver felizes. Porém, durante o processo de produção da segunda estória observa-se diversos momentos em que se explicita vontade em fazer uma estória diferente, que seja do PETI. Essa identidade acaba envolvendo outras questões, que não as representações. Apesar das mensagens

\footnotetext{
${ }^{38}$ Segundo Woodwark, "um sistema classificatório aplica um princípio de diferença a uma população de uma forma tal que seja capaz de dividi-la em pelo menos dois grupos opostos - nós/eles; eu/outro" (2004 p. 40).
} 
por trás das estórias serem as mesmas, seus elementos, personagens e ambientes são suficientes para fazer a estória ser diferente para este grupo.

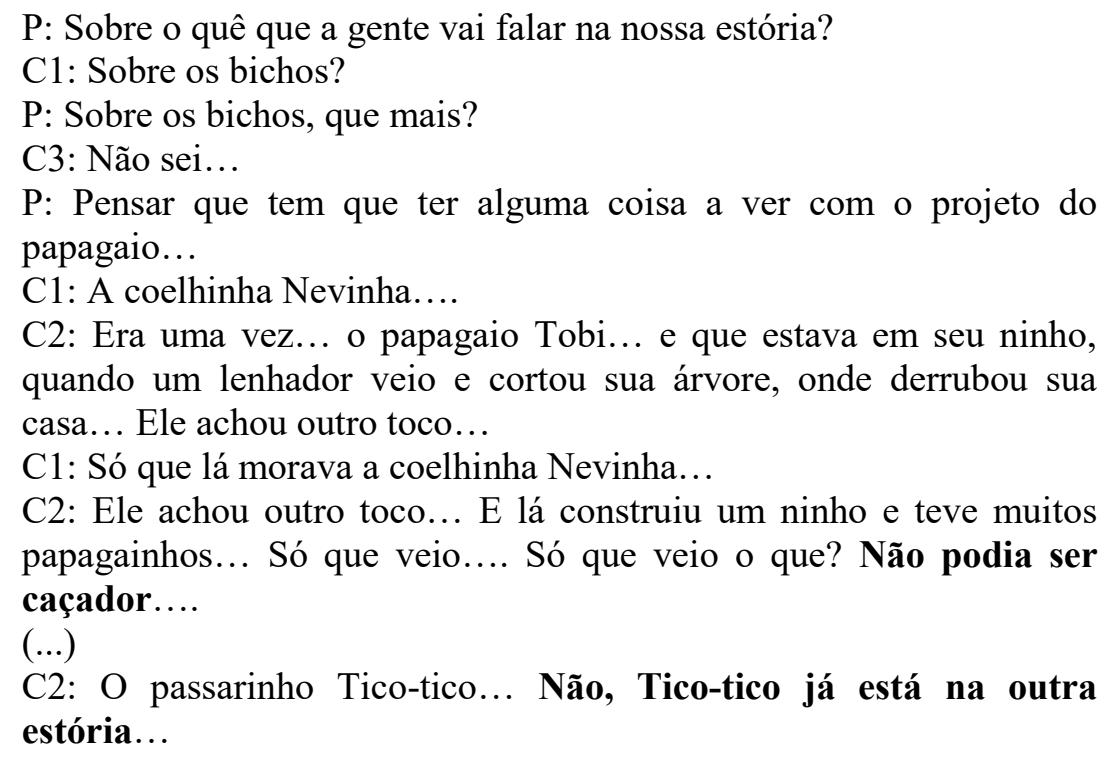

(Grupo 1, Episódio 1b)

Já no segundo episódio selecionado relacionado à identidade, o elemento central se dá nas tensões entre identidade individual e identidade coletiva. No Episódio 5 do Grupo 1, observou-se que a criança mais velha $(\mathrm{C} 2)$ foi a principal condutora das atividades de criação e de narração. Apesar da C2 ter criado a estória praticamente sozinha, aceitando ajuda dos outros apenas em alguns momentos, as outras aceitaram sua narrativa e sua figura enquanto uma liderança do grupo. Essa aceitação ajuda a exemplificar, ainda que superficialmente, a concepção de que as identidades possuem contradições e heterogeneidades internas (WOODWARK, 2014). Assim, as diferenças internas (no nível individual) das ideias e representações sugeridas são relevadas frente ao produto final (nível coletivo), tendo que haver processos de escolha e de exclusão. Ao longo da produção de "Tobi, Susu e a tempestade", a C2 teve maior influência nas escolhas do produto final do que as demais envolvidas, sem haver grandes discordâncias explícitas.

Criança 4: Só você fala... (se referindo à criança 1)

C1: Mas vocês não falam nada, eu vou detalhando... (inteligível)

(Grupo 1, Episódio 1b)

Em outro exemplo dessa tensão entre a identidade e diferença se dá nos dilemas entre identidade individual e coletiva, pode-se analisar as estórias que são compostas por trechos produzidos ora individualmente ora coletivamente. O processo de criação de "O papagaio-depeito-roxo e a Bruxa!" foi dividido em três momentos dentro do Grupo 6 por ter acontecido ao 
longo de três encontros. No primeiro encontro, o grupo inteiro decidiu as personagens da estória bem como seu argumento: uma bruxa que tentava prender um papagaio-de-peito-roxo em uma gaiola. Já no segundo momento, a estória foi finalizada com base na escolha do Grupo 6 por uma equipe menor, composto por quatro crianças com ajuda do pesquisador, enquanto as outras crianças desenhavam as personagens. Como descrito anteriormente, no segundo encontro as crianças trabalharam de maneira livre nas funções que escolheram, sendo essa a equipe de roteiristas. Dentro dessa equipe de roteiristas, uma das crianças (Criança 3, Grupo 6) liderou a criação da estória, realizando quase todas as decisões enquanto registrava em uma folha de papel, de maneira praticamente individual. No terceiro momento, a produção voltou a ser realizada com o grupo completo, dessa vez com o registro feito pelo pesquisador. Dessa forma, para essa criança, as primeiras frases adquiriram um caráter de diferenciação em relação ao resto da estória por terem sido produzidas praticamente por ela mesma sozinha.

Criança 3: Fui eu que fiz a estória... É a mesma, a mesma coisa que eu... eu que escrevi, fui eu que escrevi, não é, profe, que fui eu que escrevi?

Pesquisador: Você escreveu o começo: essas partes foi você que escreveu... Aí daqui pra frente a gente fez juntos.

C3: É...

P: Então você pode ler essas duas primeiras, que foi você e as outras a gente divide com as amigas, pode ser?

C3: Sim!

(Grupo 6, Episódio 3)

Apesar de reivindicar a leitura inicial dos trechos de sua autoria dentro do grupo, nos momentos de gravação para a produção da radionovela não houve tal demanda e os turnos de fala foram divididos à medida que as crianças demonstravam interesse em fazer a locução.

Com isso, nesse capítulo foram descritos quatro modos de participação que emergiram de práticas participatórias de DC com cocriação de mídias. Vale ressaltar que todos os modos de participação tiveram relação com a produção, uma vez que a prática de DC analisada nesta pesquisa pode ser enquadrada como uma ação de cocriação de conhecimentos e produtos (METCALFE, 2019), ou seja, se baseia justamente nos processos produtivos das crianças junto com o pesquisador. Nesta dissertação, algumas dimensões do circuito da cultura foram apresentadas em apenas alguns modos específicos de participação, mas compreende-se que elas também estão presentes nas demais. Entretanto, esse nível de detalhamento não era intuito desta pesquisa, uma vez que o objetivo está em descrever os diferentes modos de Participação Infantil e refletir sobre suas limitações e possibilidades de atuação. Ainda, observou-se uma relação 
dialética tanto entre as dimensões do circuito da cultura, quanto entre os modos de participação e essas dimensões. Enquanto as dimensões do circuito da cultura interagem e se transformam nessa interação, os entendimentos dos modos de participação e a própria forma com que as crianças participam transformaram as diferentes dimensões e foram transformadas pelas mesmas durante esse processo. 


\section{Considerações finais}

O objetivo geral dessa pesquisa buscou a compreensão dos modos de Participação Infantil na Divulgação Científica, considerando-se a cultura da infância e modelos participatórios de comunicação da ciência. Para isso, foram propostas e analisadas ações educativas de caráter participatório realizadas em parceria com o Instituto Espaço Silvestre. Tais ações focaram na cocriação de produtos em forma das mídias "rádio" e "audiovisual" com a participação de crianças ao longo do processo produtivo. Como resultado das análises, quatro modos de participação das crianças nas ações emergiram.

O primeiro modo observado foi a participação contextualizada, ou seja, aquela em que a criança participa ao incorporar elementos de seu próprio contexto, que pode ser por meio de elementos locais ou de suas culturas da infância. Esse modo se relaciona fortemente com a dimensão da identidade (dentro do Circuito da Cultura), uma vez que ao participar dessa forma, a criança está construindo a visão de si, do local em que vive e compartilhando seus conhecimentos no conteúdo dos produtos finais. Relaciona-se também com a questão das regulações pois há diversas normas, implícitas e explícitas, das diferentes instituições envolvidas a serem compreendidas. Nesse sentido, observou-se a relação entre elementos da identidade e as regras regulatórias, com influência em ambos os sentidos, ou seja, as regras e normas do pesquisador alterando os elementos das identidades locais e das culturas infantis presentes no produto final, ao mesmo tempo em que essas identidades alteram algumas normas ao longo das ações.

O segundo modo descrito foi a participação simbólica, ou seja, aquela em que a criança participa ao contribuir com a construção dos elementos simbólicos presentes nas narrativas e mídias produzidas. Foi considerado a representação como a dimensão central nesse modo de participação, ainda que tenha relação com as outras dimensões também. Nesse sentido, discutiuse como a estrutura narrativa pode promover ou limitar esse tipo de participação das crianças, uma vez que estórias demasiadamente simples e que não possuem episódios completos, ou seja, dilemas ou problemas que surgem aos protagonistas e que devem ser superados (STEIN; GLENN, 1975), se limitam a descrever cenários e personagens sem colocar em pauta a resolução de problemas ou dilemas. Em relação ao conteúdo das estórias, outros elementos de análise importantes para a questão da representação foram as relações entre o Bem e o Mal ao longo das narrativas e as relações entre ser humano e natureza. Dessa forma, a dimensão da 
regulação também se mostrou presente durante a descrição desse modo de participação, uma vez que, novamente, as regras e normas implícitas e explícitas alteraram a maneira como as representações são construídas até se obter o produto final.

O terceiro modo discutido foi a participação técnica/estética, ou seja, aquela em que a criança participa das decisões ou do resultado das questões relacionadas à técnica de produção (nesse caso, mídias "rádio" e "audiovisual”) ou estética dos produtos finais. Nesse sentido, esse modo de participação se relaciona fortemente com a dimensão da produção por estar focado em como as crianças se apropriam e participam das decisões em relação ao produto final em forma de mídia, tanto nos seus processos tecnológicos e operacionais quanto em sua expressão artística.

O quarto e último modo observado foi a participação identitária, ou seja, aquela em que a criança (ou grupo de crianças) participa ao construir e reivindicar sua identidade durante os processos de coprodução. Diferentemente da participação contextualizada, nesse modo de participação a questão da identidade é observada pela tensão identidade e diferença, podendo ser observada ainda dentro de um mesmo grupo pelas tensões entre identidade individual e coletiva.

Não era o intuito desta pesquisa caracterizar e esgotar a discussão em torno das ações participatórias de DC realizadas para e com as crianças. Mesmo assim, os resultados obtidos dão suporte para importantes reflexões acerca desse tipo de prática. Uma reflexão muito presente ao longo do texto se ancora nos desafios que esse tipo de prática pode proporcionar durante a sua execução. De maneira geral, a interação dialética entre as regulações do mundo adulto e do mundo das crianças surge como um desafio ao longo de todo o processo de cocriação. Nesse sentido, diversas foram as negociações para que fosse possível atender tanto às demandas e normas do projeto do IES quanto para abraçar os elementos das culturas da infância que, em um primeiro momento, fugiam às normas regulatórias da DC. Um exemplo empírico dessa negociação se deu na relação entre regulação e a representação antagônica do Bem e do Mal. Apesar de uma visão dicotomizada e maniqueísta da existência de entidades do Bem e do Mal poder ter diversas críticas dentro da área de DC, é um importante elemento das brincadeiras e jogos das crianças, sendo capaz de promover outros tipos de debate como questões morais e éticas. 
Espera-se que os argumentos e discussões trazidos ao longo do texto possam contribuir tanto para que novas pesquisas sejam realizadas, quanto para a promoção de práticas participatórias para e com crianças na DC. Desse modo, considera-se que essa pesquisa constitui um importante passo, ainda que inicial, na sistematização desse diálogo entre as áreas de pesquisas e práticas de DC participatórias e os estudos sociais da infância.

Por fim, considera-se também que desse trabalho emergem inovadores modos de encarar a Participação Infantil nos processos de produção da DC. Vale reafirmar a importância das pesquisas relativas a como as crianças consomem materiais de DC, entretanto, essa pesquisa ressalta importantes contribuições das culturas da infância nas demais dimensões culturais (para além do consumo) que compõe o processo da cocriação de mídias para a DC. É esperado também que a discussão não se encerre na questão da coprodução de mídias, mas que as crianças possam cada vez mais exercer sua participação nos demais modos de comunicação da ciência como: museus, revistas, programas de televisão, eventos, feiras de ciência, cocriação de jogos educativos, entre outros, além dos espaços escolares e demais instituições educativas. 


\section{Referências}

ALMEIDA, Sheila Alves de; GIORDAN, Marcelo. A revista Ciência Hoje das Crianças no letramento escolar: a retextualização de artigos de Divulgação Científica. Educação e Pesquisa, São Paulo, v. 40, n. 4, p. 999-1014, 2014.

ANDRADE, Mario de. Amar, verbo intransitivo. Belo Horizonte: Villa Rica, 1995.

ARIÈS, Philippe. História social da criança e da família. 2. ed. Rio de Janeiro: Guanabara, 1986.

ARNSTEIN, Sherry R. A ladder of citizen participation. Journal of the American Institute of planners, Cambridge, v. 35, n. 4, p. 216-224, 1969.

BACHELARD, Gaston. A poética do devaneio. São Paulo: Martins Fontes, 2009.

BETTELHEIM, Bruno. A psicanálise dos contos de fadas. São Paulo: Paz e Terra, 2002.

BIZERRA, Alessandra et al. Crianças pequenas e seus conhecimentos sobre microrganismos. In: VII Encontro Nacional de Pesquisa em Educação em Ciências, 7, Florianópolis, 2009. Anais do VII ENPEC, Florianópolis: FaE UFMG, 2009.

BUCCHI, Massimiano; TRENCH, Brian (Ed.). Handbook of public communication of science and technology. Abingdon: Routledge, 2008.

BURGESS, Jacquelin; CHILVERS, Jason. Upping the ante: a conceptual framework for designing and evaluating participatory technology assessments. Science and Public Policy, Oxford, v. 33, n. 10, p. 713-728, 2006.

CASTELFRANCHI, Yuri. Por que comunicar temas de ciência e tecnologia ao público? (Muitas respostas óbvias... mais uma necessária). In: MASSARANI, Luisa. (Coord.). Jornalismo e ciência: uma perspectiva ibero-americana. 1. ed. Rio de Janeiro: Fiocruz / COC/Museu da Vida, p. 13-21, 2010.

CDB - Convention on Biological Diversity. Banco de Dados. Disponível em: $<$ https://www.cbd.int/>, acesso em $30 \mathrm{dez} 2019$. 
CONSTANT, Natasha; ROBERTS, Liz. Narratives as a mode of research evaluation in citizen science: understanding broader science communication impacts. Journal of science communication, Trieste, v. 16, n. 4, p. A03, 2017.

CORSARO, William A. Sociologia da Infância. Porto Alegre: Penso, 2011.

DAVIES, Sarah R.; HORST, Maja. Science communication: Culture, identity and citizenship. New York: Springer, 2016.

DREHER, Tanja. A partial promise of voice: Digital storytelling and the limits of listening. Media International Australia, Swinburne, v. 142, n. 1, p. 157-166, 2012.

DU GAY, Paul et al. Doing cultural studies: The story of the Sony Walkman. New York: Sage, 1997.

DURAND, Gilbert. As estruturas antropológicas do imaginário: introdução à arquetipologia geral. São Paulo: WMF Martins Fontes, 2012.

EINSIEDEL, Edna F. Public participation and dialogue. In: BUCCHI, Massimiano; TRENCH, Brian (Ed.). Handbook of public communication of science and technology. Abingdon: Routledge, p. 173-184, 2008.

ESTÉTICA. In: DICIONÁRIO Michaelis. Disponível em: <http://michaelis.uol.com.br> Acesso em: 30 dez 2019.

FALCÃO, Douglas. A divulgação da astronomia em observatórios e planetários no Brasil. ComCiência [online], Campinas, n. 112, p. 0-0, 2009.

FRANCIS, Mark; LORENZO, Ray. Seven realms of children's participation. Journal of Environmental psychology, Cambridge, v. 22, n. 1-2, p. 157-169, 2002.

FRANKLIN, Barbara. The ladder of participation in matters concerning children. In: BOYDEN, Jo; ENNEW, Judith. Children in focus: A manual for participatory research with children, Estocolmo: Grafisk Press, 1997.

GARZA, Guadalupe Zamarrón. Primeiros passos da revista Chispa. In: MASSARANI, Luisa (Org). O pequeno cientista amador: a Divulgação Científica e o público infantil. Rio de Janeiro: Vient \& Lent/UFRJ, Casa da Ciência/FIOCRUZ, p. 33-46, 2005. 
GOHN, Maria da Glória. Educação não-formal, participação da sociedade civil e estruturas colegiadas nas escolas. Revista Ensaio-Avaliação e Políticas Públicas em Educação, Rio de Janeiro, v. 14, n. 50, p. 11-25, 2006.

GONZÁLEZ ARRIBAS, Luisa Fernanda. Divulgación de la ciencia para niños a través de revistas producidas en México: aproximación a partir de las estrategias editoriales y discursivas. Dissertação (Mestrado em Comunicación de la Ciencia y la Cultura). Instituto Tecnológico y de Estudios Superiores de Occidente, Departamento de Estudios Socioculturales, Tlaquepaque, 2007.

GOUVÊA, Guaracira. A revista Ciência Hoje das Crianças e práticas de leituras do público infantil. In: MASSARANI, Luisa (Org). O pequeno cientista amador: a Divulgação Científica e o público infantil. Rio de Janeiro: Vient \& Lent/UFRJ, Casa da Ciência/FIOCRUZ, p. 47-57, 2005.

HART, Roger. Children's Participation. From Tokenism to Citizenship. Florence: UNICEF. 1992.

IBGE, Instituto Brasileiro de Geografia e Estatística. Acesso à Internet e à televisão e posse de telefone móvel celular para uso pessoal: 2017. Rio de Janeiro: IBGE, 2017.

ISZLAJI, Cynthia. A criança nos museus de ciências: análise da exposição Mundo da Criança do Museu de Ciência e Tecnologia da PUCRS. 256 f. Dissertação (Mestrado em Ensino de Ciências) - Ensino de Ciências (Física, Química e Biologia), Universidade de São Paulo, São Paulo, 2012.

JENKINS, Henry et al. Confronting the challenges of participatory culture: Media education for the 21st century. Chicago: MacArthur Foundation, 2006.

JENKINS, Henry; DEUZE, Mark. Convergence culture. Convergence: The International Journal of Research into New Media Technologies, London, Los Angeles, New Delhi, Singapore, v. 14, n. 1, p. 5-12, 2008.

JIMÉNEZ, Antonio Mateos. Concepciones sobre algunas especies animales: ejemplificaciones del razonamiento por categorías. Dificultades de aprendizaje asociadas. Enseñanza de las ciencias: revista de investigación y experiencias didácticas, Barcelona, Valência, v. 16, n. 1, p. $147-157,1998$. 
LANSDOWN, Gerison. Children's Rights. In: MAYALL, Berry (Ed.). Children's childhoods: Observed and experienced. East Sussex: Psychology Press, p. 33-45, 1994.

LEHR, Jane L. et al. The value of "dialogue events" as sites of learning: An exploration of research and evaluation frameworks. International Journal of Science Education, United Kingdon, v. 29, n. 12, p. 1467-1487, 2007.

LEPORO, Natalia. Pequenos visitantes na exposição "o mundo gigante dos micróbios": um estudo sobre a percepção. Dissertação (Mestrado em Ensino de Biologia) - Ensino de Ciências (Física, Química e Biologia), Universidade de São Paulo, São Paulo, 2015.

LEWENSTEIN, Bruce V. Models of public communication of science and technology. Public Understanding of Science, Berlin, v. 16, p. 1-11, 2003.

MALONE, Karen; HARTUNG, Catherine. Challenges of participatory practice with children. In: PERCY-SMITH, Barry; THOMAS, Nigel (ed). A handbook of children and young people's participation: Perspectives from theory and practice. 1. ed. New York: Routledge, p. 24-38, 2009.

MASSARANI, Luisa et al. O pequeno cientista amador: a Divulgação Científica e o público infantil. Rio de Janeiro: Vient \& Lent /UFRJ, Casa da Ciência/FIOCRUZ, 2005.

MCTI, Ministério de Ciência, Tecnologia e Inovação. Percepção pública da ciência e tecnologia. Brasília: Centro de Gestão e Estudos Estratégicos, 2015.

MCTI, Ministério de Ciência, Tecnologia e Inovação. Percepção pública da ciência e tecnologia. Brasília: Centro de Gestão e Estudos Estratégicos, 2019.

MERIGOUX, Daniel Ribeiro. Divulgação científica, a barreira da linguagem: univocidade e acumulação de conhecimento, reprodução e desigualdades simbólicas. Tese (Doutorado em Ciência da Informação) - Ciência da informação, Universidade Federal do Rio de Janeiro, Rio de Janeiro, 2014.

METCALFE, Jenni. Comparing science communication theory with practice: An assessment and critique using Australian data. Public Understanding of Science, Berlin, v. 28, n. 4, p. 382-400, 2019. 
MEURK, Carla et al. Media and evidence-informed policy development: the case of mental health in Australia. Contemporary Social Science, United Kingdon, v. 10, n. 2, p. 160-170, 2015.

MOREIRA, Ildeu de Castro; MASSARANI, Luisa. Aspectos históricos da divulgação científica no Brasil. In: MASSARINI, Luisa; MOREIRA, Ildeu de Castro; BRITO, Fatima. (Org.) Ciência e público: caminhos da divulgação científica no Brasil. Rio de Janeiro: Casa da Ciência-Centro Cultural de Ciência e Tecnologia da UFRJ, p. 44-64, 2002.

ONU, Organização das Nações Unidas. Convenção Sobre os Direitos das Crianças. New York, 1989. Disponível em: <https://www.unicef.org/brazil/convencao-sobre-os-direitos-dacrianca>, acesso em $30 \mathrm{dez} 2019$.

ONU, Organização das Nações Unidas. Declaração do Rio sobre Meio Ambiente e Desenvolvimento. Rio de Janeiro, 1992.

ONU, Organização das Nações Unidas. Civic engagement in public governance. World Public Sector Report. New York: UN. 2008. Disponível em: $<$ https://publicadministration.un.org/publications/content/PDFs/E-

Library\%20Archives/World\%20Public\%20Sector\%20Report $\% 20$ series/World $\% 20$ Public $\% 20$ Sector\%20Report.2008.pdf>, acesso em 30 dez 2019.

ORTHIA, Lindy. Democratizing science in the eighteenth century: resonances between Condorcet's Sketch (1795) and twenty-first century science communication. Journal of Science Communication, Trieste, v. 15, n. 4, p. A04, 2016.

PERCY-SMITH, Barry; THOMAS, Nigel. A Handbook of Children's Participation: perspectives from Theory and Practice. Abingdon: Routledge, 2010.

POTTER, Martin. Critical junctures: place-based storytelling in the Big Stories, Small Towns participatory documentary project. Media International Australia, Swinburne, v. 164, n. 1, p. 117-127, 2017.

REINSBOROUGH, Michael. Science fiction and science futures: considering the role of fictions in public engagement and science communication work. Journal of Science Communication, Trieste, v. 16, n. 4, p. C07, 2017. 
ROCK, Jenny; MCGUIRE, Mark; ROGERS, Alexandra. Multidisciplinary perspectives on cocreation. Science Communication, Corvallis, v. 40, n. 4, p. 541-552, 2018.

ROYDS, Kelly. Listening to Learn: Children's Experiences of Participatory Video for Global Education in Australia and Timor-Leste. Media International Australia, Swinburne, v. 154, n. 1, p. $67-77,2015$.

RUBIRA, Fabiana de Pontes. Contar e ouvir estórias: um diálogo de coração para coração acordando imagens. Dissertação (Mestrado em Linguagem e Educação) - Faculdade de Educação, Universidade de São Paulo, São Paulo, 2006.

SALVIO, Paula M. Exercising 'the right to research': Youth-based community media production as transformative action. English in education, Bristol, v. 47, n. 2, p. 163-180, 2013.

SARMENTO, Manuel Jacinto. Imaginário e culturas da infância. Cadernos de Educação, Pelotas, v. 12, n. 21, p. 51-69, 2003.

SARMENTO, Manuel Jacinto. As culturas da infância nas encruzilhadas da $2^{\mathrm{a}}$ modernidade. In: SARMENTO, Manuel Jacinto. Crianças e miúdos: perspectivas sócio-pedagógicas da infância e educação. Porto: Asa, p. 9-34, 2004.

SARMENTO, Manuel Jacinto. A reinvenção do ofício de criança e de aluno. Atos de pesquisa em educação, Blumenau, v. 6, n. 3, p. 581-602, 2011.

SATO, Marcelo Kei; PRADO, Mariana Antonieta Barros do. A contação e recontação de estórias como ferramenta para o Ensino de Ciências na Educação Infantil: experimentação para e com as crianças. In: VII Congresso Paulista de Educação Infantil \& III Simpósio Internacional de Educação Infantil, 7, São Carlos, 2015. Anais do VII Congresso Paulista de Educação Infantil \& III Simpósio Internacional de Educação Infantil. Vol. 2. São Carlos: UFSCar, p. 352-361, 2015.

SATO, Marcelo Kei et al. O imaginário ambiental na tradição oral: contos e mitos sobre animais como ferramenta para o Ensino de Biologia. In: SILVA, Rosana Louro Ferreira; SILVA, Gabriel de Moura (Org.). Possibilidades didáticas para o ensino de Zoologia na educação básica - volume III. São Paulo: Instituto de Biociências da Universidade de São Paulo, p. 297$303,2016$. 
SCALFI, Graziele Aparecida de Moraes. Fauna brasileira retratada na literatura infantil: instrumento para a Divulgação Científica. 331 f. Dissertação (Mestrado em Divulgação Científica) - Divulgação Científica e Cultural, Universidade Estadual de Campinas, Campinas, 2014.

SHIER, Harry. Pathways to participation: Openings, opportunities and obligations. Children \& society, London, v. 15, n. 2, p. 107-117, 2001.

SIQUEIRA, Denise da Costa Oliveira. Ciência na televisão: mito, ritual e espetáculo. Intercom-Revista Brasileira de Ciências da Comunicação, Belém, v. 21, n. 2, p. 57-69, 1998.

SIQUEIRA, Denise da Costa Oliveira. Superpoderosos, submissos: os cientistas na animação televisiva. In: MASSARANI, Luisa (Org). O pequeno cientista amador: a Divulgação Científica e o público infantil. Rio de Janeiro: Vient \& Lent/UFRJ, Casa da Ciência/FIOCRUZ, p. 23-32, 2005.

SIQUEIRA, Denise da Costa Oliveira. Televisão e Divulgação Científica. ComCiência [online], Campinas, n. 100, p. 0-0, 2008.

SOARES, Natália Fernandes. Os direitos das crianças nas encruzilhadas da proteção e da participação. Zero-a-Seis, Florianópolis, v. 7, n. 12, p. 8-18, 2005.

STEIN, Nancy L.; GLENN, Christine G. An Analysis of Story Comprehension in Elementary School Children: A Test of a Schema. Washington: ERIC Clearinghouse, 1975. STORNAIUOLO, Amy; THOMAS, Ebony Elizabeth. Disrupting educational inequalities through youth digital activism. Review of Research in Education, Chicago, v. 41, n. 1, p. 337 $357,2017$.

STUDART, Denise Coelho. Aparatos interativos e o público infantil em museus: características e abordagens. In: MASSARANI, Luisa (Org). O pequeno cientista amador: a Divulgação Científica e o público infantil. Rio de Janeiro: Vient \& Lent/UFRJ, Casa da Ciência/FIOCRUZ, p. 65-76, 2005a.

STUDART, Denise Coelho. Museus e famílias: percepções e comportamentos de crianças e seus familiares em exposições para o público infantil. História, Ciências, Saúde-Manguinhos, Rio de Janeiro, v. 12, supl. p. 55-77, 2005 b. 
THOMAS, Nigel. Towards a theory of children's participation. The International Journal of Children's Rights, United Kingdon, v. 15, n. 2, p. 199-218, 2007.

TRENCH, Brian. Science communication and citizen science: how dead is the deficit model. In: IX International Conference on Public Comunication of Science and Technology (PCST), Seoul, 2006. PCST-9 Proceedings. Disponível em $<$ https://pcst.co/archive/pdf/Trench_PCST2006.pdf $>$, acesso em 03 jan 2020.

TRENCH, Brian. Towards an analytical framework of science communication models. In: CHENG, Donghong et al. Communicating science in social contexts. New York: Springer, p. 119-135, 2008.

TRESEDER, Phil; SMITH, Pat Gordon. Empowering Children \& Young People: Training Manual. London: Save the Children, 1997.

TURNEY, Jon. Popular science books. In: BUCCHI, Massimiano; TRENCH, Brian (Ed.). Handbook of public communication of science and technology. Abingdon: Routledge, p. 19-28, 2008.

UNEP, United Nations Environment Programme. Putting Rio Principle 10 Into Action: An Implementation Guide. Nairobi: UNON/Publishing Services Section, 2015.

URSI, Suzana et al. Influência de exposição interativa sobre ambiente marinho e sua biodiversidade nas concepções de meio ambiente de estudantes do ensino fundamental. Enseñanza de las ciencias, Barcelona, Valência, n. extra, p. 3575-3580, 2013.

VERVOORT, Joost et al. A sense of change: media designers and artists communicating about complexity in social-ecological systems. Ecology and Society, Wolfville, v. 19, n. 3, 2014.

VIGOTSKI, Lev. A formação social da mente. São Paulo: Martins Fontes, 1994.

VIGOTSKI, Lev. Imaginação e Criatividade na Infância. São Paulo: WMF Martins Fontes, 2014.

WOODWARD, Kathryn; Identidade e Diferença: uma introdução teórica e conceitual. In: HALL, Stuart; WOODWARD, Kathryn; SILVA, Tomaz Tadeu da. Identidade e diferença. Belo Horizonte: Vozes, p. 7-72, 2014. 


\section{APÊNDICE 1}

\section{A floresta escondida}

Era uma vez Bob, o papagaio-de-peito-roxo.

Ele estava voando e encontrou duas ararinhas-azuis: Rosa e Michel, a Coruja Zuzu, o Pica-pau Amarelinho e o Tucano Fred.

Começaram a brincar e cantar.

De repente, apareceu um caçador! O caçador capturou todos, menos o Bob. Ele saiu voando para chamar ajuda.

Encontrou Bunga, o javali, Sussurro, a Raposa e Beca, a Lebre. Então foram salvar seus amigos.

Bunga mordeu o caçador.

Sussurro correu bem rápido e destrancou as gaiolas.

E Beca carregou os amigos para longe.

O caçador morreu e os animais foram para uma mata escondida em que só era possível entrar por cima, voando.

Os que não voavam cavaram um túnel e entraram por baixo, onde só eles passavam.

Já acabou, fim! 


\section{APÊNDICE 2}

Tobi, Susu e a tempestade

Era uma vez, Tobi e Susu. Estavam conversando em sua casa quando um lenhador veio e derrubou sua casa. Encontraram a coelhinha Nevinha. Pediram ajuda para encontrar uma nova casa. Conseguiram encontrar um toco e fizeram um ninho.

Tiveram três filhotinhos, Rosa, Roxinho e Bibi.

De repente, o viado Pintadinho, o passarinho Pipito, a borboleta Tutu e o Beija-Flor.

Estavam todos correndo, Tobi perguntou:

- O quê que deu?

- Está vindo uma grande tempestade - eles responderam.

Tobi e Susu só conseguiram pegar Roxinho. Rosa e Bibi se perderam.

Levaram dias para procurar, até que num certo dia encontraram eles presos numa gaiola. Conseguiram descobrir que o nome da mulher era Dona Benta. O viado Pintadinho bateu na porta com seu chifre e a Dona Benta não pensou duas vezes: "Vou pegar ele também!".

Enquanto Pipito, Tutu, Beija-flor, Nevinha, Tobi e Susu tentavam abrir a gaiola, até que Susu conseguiu abrir e saíram todos correndo. Conseguiram despistar Dona Benta.

Encontraram atrás de uma cachoeira uma caverna, onde todos iriam morar juntos. Ali era seguro, não vinha tempestade, ninguém conseguia achar.

Ali moraram todos juntos: Pintadinho, Pipito, Tutu, Beija-Flor, Nevinha, Tobi, Susu, Rosa, Roxinho e Bibi.

Viveram felizes para sempre!

Fim 


\section{APÊNDICE 3}

\section{Papagaios Chico e Chica}

Em um belo dia na mata, os animais estavam brincando. E quando se cansaram, foram nadar em uma cachoeira.

De repente, chegou um caçador, que queria sequestrar os papagaios-de-peito-roxo. Mas tinha dois do bando: Chico e Chica, que lutaram pela liberdade de seus amigos. Os caçadores estavam caçando os passarinhos quando passaram embaixo de um pinheiro.

Derrubaram uma pinha na cabeça deles! Chamaram os gaviões para picar a cabeça deles.

Os caçadores fugiram com medo. Então, os animais de todas as espécies festejaram pela vitória. Os animais viveram felizes para sempre.

Os caçadores maus prometeram nunca mais voltar.

Fim! 


\section{APÊNDICE 4}

\section{Os animais da mata}

Era uma vez o Papagaio-de-peito-roxo Louro e seus amigos: o Tamanduá Zé-pilim, o Periquito Cadu e o Javali Zeca. Estavam brincando na mata, quando de repente viram uma cobra! Seu nome era Naja, e queria comer os ovos do Louro.

Os animais se assustaram e tentaram salvar os ovos, mas Zeca foi picado e desmaiou!

Os animais lhe carregaram para a floresta para poder cuidar dele. Depois de cuidarem do javali ele ficou bem. Na mata encontraram uma armadilha e a usaram para tentar pegar a Naja.

A cobra caiu na armadilha e os amigos estavam pensando o que fazer com ela. Enquanto conversavam apareceu uma onça! Os animais sabiam que a única que podia salvá-los era a Naja, então pediram para a cobra que os ajudassem. E pra isso tiveram que tirar ela da armadilha.

Naja os ajudou e a Onça saiu toda machucada.

Assim, a cobra virou amiga deles e todos festejaram.

Muito tempo depois a onça voltou sem amigos e pediu perdão.

Com o perdão dos animais, ficaram amigos e todos viveram felizes para sempre!

Fim. 


\section{APÊNDICE 5}

\section{O Papagaio Rico e os seus amigos}

Era uma vez o Papagaio Rico, que encontrou todos os seus amigos na floresta.

Era um lugar lindo cheio de árvores!

Nesse lugar estava o Periquito Chico, o Tucano Tuco, o Porquinho Vitor e o Cavalo Trovão.

Todos brincavam de pega-pega na floresta, muito felizes.

O Periquito Chico era lindo, de cor amarela.

O Tucano Tuco era preto com vermelho e bico amarelo. Adorava voar pela floresta.

Já o Porquinho Vitor era rosa, mas vive sujo porque gosta de brincar na lama.

E o Cavalo Trovão gosta de correr e é marrom.

São muito amigos, brincam juntos e adoram a floresta, porque lá tem: árvores, rios, lama e muitos animais.

E vivem felizes na floresta.

Fim 


\section{APÊNDICE 6}

\section{O Papagaio Dedé e o Dragão!}

Era uma vez o papagaio-de-peito-roxo Dedé, o pato voador Amarelinho, o cavalo Feliz e a Águia.

Eles estavam brincando no campo quando começou a chover. Foram para a mata esperar a chuva passar. Quando a chuva passou tinha um arco-íris, muita lama e fez sol, mas ele estava diferente: ele estava todo preto. Era um Eclipse!

Enquanto esperavam o sol voltar ao normal, fizeram uma fogueira e brincaram em volta dela. Para apagar o fogo jogaram água do rio e folhas molhadas. Foram dormir e ao acordarem foram trabalhar.

O Papagaio Dedé foi trabalhar na roça. Plantava pinhão. Além de pinhão, milho, maçã e outras frutas.

O Pato Amarelinho foi pescar peixes.

O Cavalo Feliz foi correr.

E a Águia foi comer galinhas.

Quando voltaram, foram fazer o jantar. E apareceu um predador... Era um Dragão! E ele estava com fome, parecia que ia comer todo mundo.

Se comesse o Papagaio Dedé, ele não ia mais plantar pinhão.

Se comesse o Pato Amarelinho, ele não ia mais pescar peixe.

Se comesse o Cavalo Feliz, ele não ia mais correr.

Mas o Dragão foi convidado e se juntou para o jantar.

Depois de comerem, todos brincaram e dançaram juntos.

Fim! 


\section{APÊNDICE 7}

\section{Os passarinhos e o Monstro de Ferro!}

O Tucano Rico, a Coruja Esperta, o Sapo Cururu, o Gavião Marcelinho, o Tesourinha Quico e o Papagaio Tico-tico estavam brincando na floresta.

Brincavam de pego-pego e pego cola. Depois contaram histórias e cantaram.

Então, foram tomar água, comer e dormir.

Comeram frutas, semente, amorinha, laranja, moranguinho, vergamota, uva, maçã, tomate... Foram dormir na casa deles no ninho. O papagaio dormia nas árvores, em um tronco lá no céu.

Quando acordaram foram brincar na floresta com os amigos e aproveitaram para pegar as flores. Deram as flores para a mãe deles.

Foram passear! Mas se perderam no caminho e viram uma coisa no ar: era um monstro! Ele era de ferro.

Tentaram jogar pedras mas não conseguiram.

Voltaram para casa e ela estava toda quebrada. O Monstro de Ferro que quebrou...

Começaram a montar outra casa. Foram buscar suas famílias.

Depois que construíram a casa o Monstro ficou nervoso.

Tinha tanta raiva...

Que explodiu!

Os pássaros voaram com medo da explosão.

Eles ficaram felizes porque mais ninguém ia destruir a casa deles.

E viveram felizes para sempre!

Fim 


\section{APÊNDICE 8}

A guerra contra os cortadores de árvores

Era uma vez um Tucano Paçoquinha, amigo do Paulo, um papagaio-de-peito-roxo.

Eram amigos dos "Amigos dos Animais", um grupo de mil crianças de Ponte Serrada que gostavam muito dos dois.

Além deles eram amigos do Quero-quero Fofura e do Tico-tico Pilho.

Estavam na floresta, brincando, comendo frutas e pinhão.

Depois de comerem, jogavam as sementes no chão e cuidavam da natureza.

Por isso, nasciam bastantes árvores e vinham muitos passarinhos.

Eles vinham porque gostavam das frutas e dos pinhões.

Vinham passarinhos de muito longe, inclusive de Catanduvas.

Os amigos fizeram uma casa nas árvores.

De repente, homens de Concórdia começaram a cortar as árvores e os animais declararam guerra!

Os homens cortavam as árvores para fazer tecido para vender.

Para ganhar a guerra, os pássaros fizeram arma de tambor e atiraram nos homens.

Além deles, outros pássaros e homens de Catanduvas vieram ajudar.

Os homens que estavam cortando as árvores fugiram de medo e os pássaros viveram felizes na floresta.

Fim 


\section{APÊNDICE 9}

\section{O papagaio-de-peito-roxo e a Bruxa!}

O papagaio-de-peito-roxo Fred estava fugindo da Bruxa Fredegunda, mas ela o pegou.

A Cobra Chuchu foi socorrer, mas a Bruxa a pegou também. O mesmo aconteceu com a Coruja Florisbela. O Pica-pau Quinquim estava voando para ajudar seus amigos.

Enquanto Quinquim picava a Bruxa, os outros animais salvaram Fred, Chuchu e Florisbela. Eles agradeceram o Pica-pau e seus companheiros:

- Obrigado por me salvar, porque lá era muito ruim - disse o Fred.

- A Bruxa dava sopa muito ruim - disse a Chuchu.

- Eu já estava ficando enjoada daquela Bruxa malvada - disse a Florisbela.

Os animais jogaram a Bruxa no fogo!

E viveram felizes para sempre.

Muito obrigado!

Fim! 


\section{APÊNDICE 10}

\section{O Papagaio e os amigos dele}

Era uma vez um papagaio-de-peito-roxo chamado Quiqui.

Ele comia as sementes de frutas e gostava de brincar com seus amigos: o Jacu Chicorico, o Cachorro Totó e o Menino Fábio. Fábio gostava muito de animais e de quem ele gostava mais era do Quiqui. Um dia eles sairam para passear.

Encontraram uma árvore cheia de maçãs. Quiqui encontrou Chico-rico preso em um tronco e Totó e Fábio foram ajudar. Fábio tirou Chico-rico do tronco e ele ficou feliz, mas estava machucado. Então Fábio o levou para cuidar dele até sarar.

Quando Chico-rico curou, Fábio gostou tanto de seu amigo que não quis mais soltá-lo.

Então Quiqui conversou com Fábio para que soltasse o Chico-rico, pois sabia que não podia pegar bichos da natureza e Chico-rico morreria parado e duro se continuasse preso.

Fábio não deu bola para Quiqui, e Chico-rico ficou muito doente e implorou para soltálo, senão ele morreria. O menino ficou com dó e soltou o Jacu.

No fim, todos continuaram amigos e passeando juntos.

Fim. 


\section{APÊNDICE 11}

\section{Termo de consentimento livre e esclarecido}

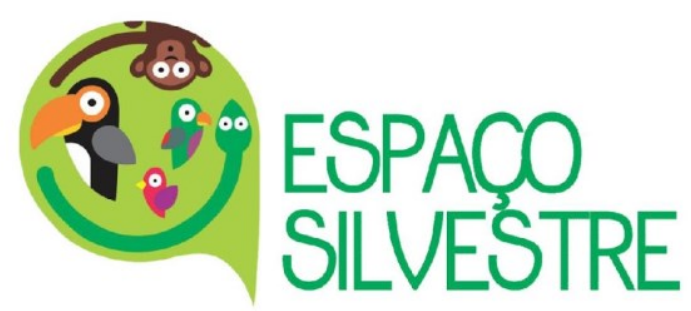

Termo de cessão de uso de imagem e áudio

$\mathrm{Eu}$, portador (a) RG responsável pelo

(a) aluno

(a) autorizo a utilização, paraos fins selecionados a seguir dos materiais registrados em áudioe vídeo, captados durante as atividades do Instituto Espaço Silvestre no "Projeto de reintrodução do papagaide-peitoroxo no Parque Nacional das Araucárias - SC", no período de março a maio de 2017

Os direitos de uso paradivulgação são de responsabilidadedo Instituto Espaço Silvestre, sendo essa uma instituição sem fins lucrativos, com apoio da Fundaçãđrupo Boticário de Proteção à Natureza Os materiais coletados serão utilizados para a produção de: (1) uma radionovela a se transmitida na Nossa Rádio 100.7 FM e; (2) um curta-metragem, com exibição online gratuita e física nas regiōes de Passos Maia, Ponte Serrada e São Paulo, com previsão para ocorrer nos meses de setembro e outubro de 2017.

Além desses fins, os materiais poderão s® utilizados para fins depesquisa, pelo aluno de mestrado Marcelo Kei Sato, do Programa Interunidades em Ensino de Ciências da Universidade de São Paulo (USP), na modalidade Ensino de Biologia. Os resultados do projeto, intitulado "Imaginação, Imaginário e Participação Infantil: contribuições da divulgação científica na construção de estórias e narrativas",serão publicados em forma de Dissertação de Mestrado, estará disponível para consulta pública online e poderá ser encaminhado pomæeil, caso haja interesse. Além disso, outros resultados provenientes dos materiais poderão ser apresentados em simpósios, encontros, congressos e publicados em periódicos acadêmicos.

$\square$ Desejo receberuma cópia dessestermos ro e-mail: 


\title{
APÊNDICE 12
}

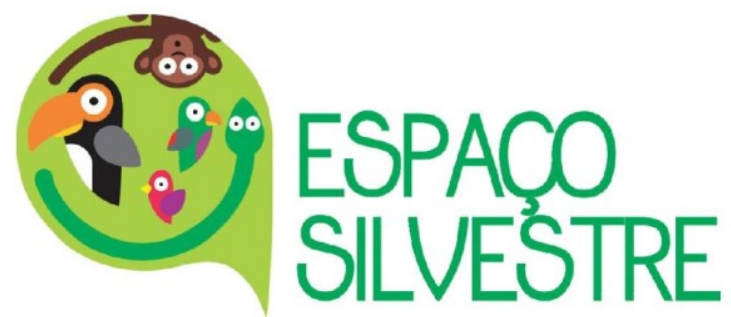

\begin{abstract}
Concedo os direitos de uso de áudio e vídeo para:
$\square$ Fins de pesquisa ede divulgação

$\square$ Apenas para fins de pesquisa

$\square$ Apenas para fins de divulgação

$\square$ Năo concedo o direito de uso de áudio e vídeo

Em caso de participação na pesquisa:

$\square$ Desejo receber os resultados da pesquisa nomail:

$\square$ Não desejo receber os resultados da pesquisa.
\end{abstract}

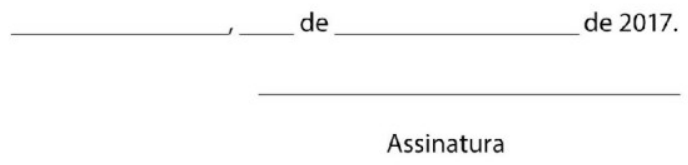

Declaro estar ciente de que, a qualquer momento, posso buscaraiores esclarecimentos junto aos responsáveisabaixo referidos.
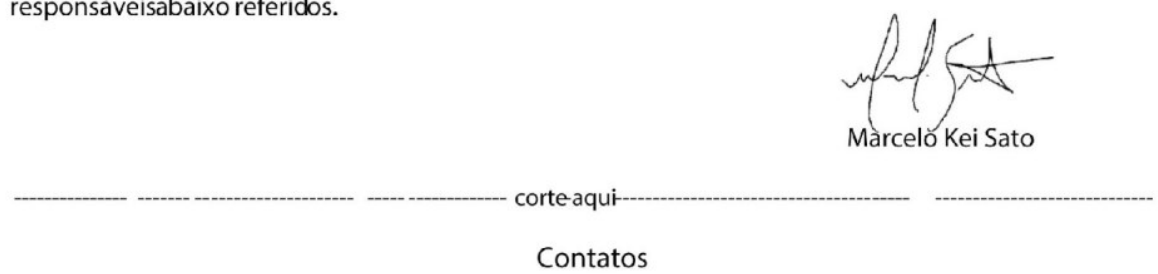

Em caso de dúvidas, guarde esses contatos para eventuabnsulta

Marcelo Kei Sato

(49) 9-9109-6469 e (11) 9-9897-0888

Instituto Espaço Silvestre

(49) $9-9805-3989$ 